\title{
DESEMPENHO OPERACIONAL DE UM SUBSOLADOR EM FunÇÃo da Estrutura, do TEOR DE Argila E DE ÁGUA EM TRÊS LATOSSOLOS
}

\author{
CASSIANO MASSAKAZU SASAKI
}

Tese apresentada à Escola Superior de Agricultura "Luiz de Queiroz”, Universidade de São Paulo, para obtenção do título de Doutor em Ciências, Área de Concentração: Recursos Florestais.

P I R A C I C A B A

Estado de São Paulo - Brasil

Fevereiro - 2005 


\title{
DESEMPENHO OPERACIONAL DE UM SUBSOLADOR EM FunÇÃo da Estrutura, do TEOR DE Argila E DE ÁGUA EM TRÊs LATOSSOLOS
}

\author{
CASSIANO MASSAKAZU SASAKI \\ Engenheiro Florestal
}

Orientador: Prof. Dr. JOSÉ LEONARDO DE MORAES GONÇALVES

P I R A C I C A B A

Estado de São Paulo - Brasil

Fevereiro - 2005 
Dados Internacionais de Catalogação na Publicação (CIP) DIVISÃO DE BIBLIOTECA E DOCUMENTAÇÃO - ESALQ/USP

Sasaki, Cassiano Massakazu

Desempenho operacional de um subsolador em função da estrutura, do teor de argila e de água em três latossolos / Cassiano Massakazu Sasaki. - - Piracicaba, 2005

82 p. : il.

Tese (Doutorado) - - Escola Superior de Agricultura Luiz de Queiroz, 2005.

Bibliografia.

1. Conservação do solo 2. Consolidação do solo 3. Cultivo mínimo 4. Preparo do solo 5. Solo florestal 6 . Subsolagem I. Título

CDD 631.3

\section{"Permitida a cópia total ou parcial deste documento, desde que citada a fonte - O autor"}




\section{AGRADECIMENTOS}

Ao Professor José Leonardo de Moraes Gonçalves, pelos ensinamentos, incentivo e amizade, que tanto contribuíram para minha formação profissional e pessoal.

Ao Professor Kléber Pereira Lanças, pela amizade e contribuições imprescindíveis à realização desta tese.

Ao amigo e colega Marcos Cesar Passos Wichert, pela amizade e amparo na realização deste trabalho.

Ao pessoal da Cia. Suzano de Papel e Celulose, em especial Gava, Ronick e Martinho, pelo apoio e amizade.

Ao CNPq, pela concessão da bolsa de estudos para a realização desta pesquisa.

À Coordenação do Programa de Pós-Graduação em Recursos Florestais da ESALQ/USP. 


\section{SUMÁRIO}

Página

LISTA DE FIGURAS.............................................................. vi

LISTA DE TABELAS ........................................................................ viii

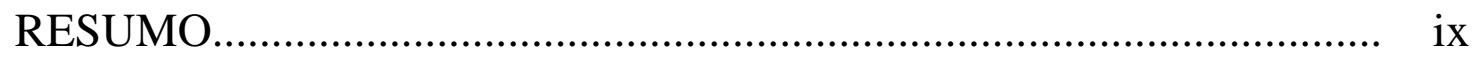

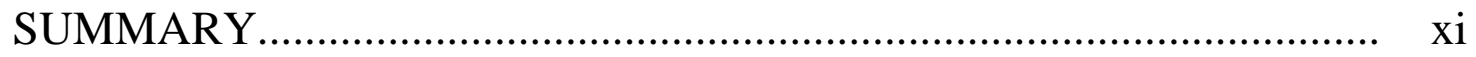

1 INTRODUÇÃO......................................................................... 1

2 REVISÃO DE LITERATURA.........................................................

2.1 O cultivo mínimo do solo.......................................................................

2.2 Definição de subsolagem e subsoladores.......................................................... 5

2.3 Avaliação do desempenho operacional de subsoladores.................................... 7

2.4 Efeitos do teor de água e do tipo de solo na subsolagem................................. 9

2.5 O processo de re-adensamento do solo........................................................ 12

3 MATERIAL E MÉTODOS.......................................................... 15

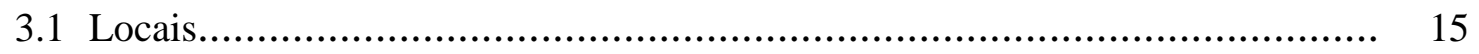

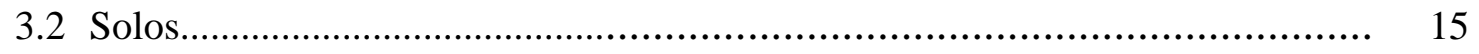


3.3 Características morfológicas, físicas e químicas dos solos.......................... 16

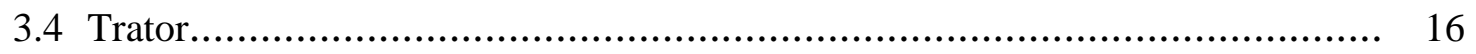

3.5 Haste subsoladora e ponteira......................................................... 18

3.6 Tratamentos experimentais...................................................... 18

3.7 Avaliação do desempenho operacional do subsolador................................ 20

3.8 Avaliação do re-adesamento do sulco de preparo.................................... 23

3.9 Ensaio de Proctor normal............................................................. 23

4 RESULTADOS E DISCUSSÃO................................................ 25

4.1 Desempenho operacional do subsolador.............................................. 25

4.2 Re-adesamento do sulco de preparo............................................... 30

4.3 Teor da água ideal para a subsolagem............................................ 33

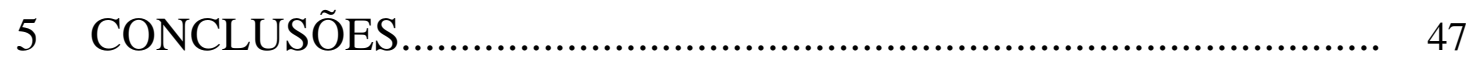

REFERÊNCIAS BIBLIOGRÁFICAS........................................... 48

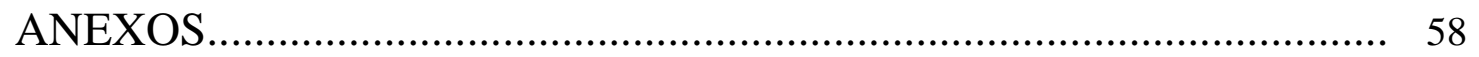




\section{LISTA DE FIGURAS}

1 Haste parabólica e dimensões da ponteira sem asas do subsolador.

2 Exemplo ilustrativo de isolinhas de resistência à penetração do solo, obtidas pelo penetrômetro de impacto. No eixo X, o ponto C está localizado na linha central de subsolagem e, os demais, à esquerda e à direita, às distâncias de 15 cm um do outro. A área em destaque é delimitada pela isolinha que corresponde à resistência à penetração antes da subsolagem (2,4 $\mathrm{MPa})$, portanto, designa a área mobilizada de solo pela subsolagem (AMS). Em tracejado, a determinação da profundidade (PET) e da largura efetiva de trabalho (LET), pelo método das zonas de resistência

3 Volume de solo mobilizado, profundidade efetiva de trabalho e largura efetiva de trabalho em função do teor de água em cada tipo de solo.

4 Capacidade teórica de trabalho, velocidade média de deslocamento e rendimento em função do teor de água em cada tipo de solo.

5 Resistência à penetração do solo, avaliada aos 0,12 e 24 meses póssubsolagem: a) Latossolo Vermelho Distrófico textura média, b) Latossolo Vermelho Distrófico textura argilosa e c) Latossolo Vermelho Distrófico textura muito argilosa.

6 Área mobilizada de solo em função do tempo pós-subsolagem e respectivos desvios padrões: a) Latossolo Vermelho Distrófico textura média, b) Latossolo Vermelho Distrófico textura argilosa e, c) Latossolo Vermelho Distrófico textura muito argilosa.. 
7 Área mobilizada de solo em função do tempo pós-subsolagem........................... 36

8 Resistência à penetração do solo, avaliada antes da subsolagem, com diferentes teores de água: a) Latossolo Vermelho Distrófico textura média, b) Latossolo Vermelho Distrófico textura argilosa e, c) Latossolo Vermelho Distrófico textura muito argilosa.

9 Variação da resistência à penetração em função da porcentagem relativa de água disponível nos três Latossolos: a) camada 0 a $10 \mathrm{~cm}$; b) camada 10 a 30 $\mathrm{cm}$.

10 Área mobilizada de solo em função do teor de água: a) Latossolo Vermelho Distrófico textura média, b) Latossolo Vermelho Distrófico textura argilosa e, c) Latossolo Vermelho Distrófico textura muito argilosa. PMP significa Ponto de Murcha Permanente (-1,5 MPa) e, CC, Capacidade de Campo (-0,01 $\mathrm{MPa})$.

11 Área mobilizada de solo em função do teor de água: a) Latossolo Vermelho Distrófico textura média, b) Latossolo Vermelho Distrófico textura argilosa e, c) Latossolo Vermelho Distrófico textura muito argilosa.

12 Curvas de compactação obtidas pelo ensaio de Proctor normal: a) Latossolo Vermelho Distrófico textura média, b) Latossolo Vermelho Distrófico textura argilosa e, c) Latossolo Vermelho Distrófico textura muito argilosa...

13 Intervalo hídrico de subsolagem em função da densidade ( - - - ), da área mobilizada ( $\_$) e do teor de água nos solos: a) Latossolo Vermelho Distrófico textura média, b) Latossolo Vermelho Distrófico textura argilosa e, c) Latossolo Vermelho Distrófico textura muito argilosa. PMP significa Ponto de Murcha Permanente (-1,5 MPa) e, CC, Capacidade de Campo (-0,01 MPa). A área hachurada representa o intervalo hídrico que a subsolagem deve ser realizada..... 


\section{LISTA DE TABELAS}

Página

1 Alguns atributos físicos, químicos e morfológicos da camada 0 a $40 \mathrm{~cm}$ dos solos.

2 Teores de água na capacidade de campo (CC, -0,01 MPa), no ponto de murcha permanente (PMP, -1,5 MPa) e por ocasião das subsolagens em cada tipo de solo estudado 


\title{
DESEMPENHO OPERACIONAL DE UM SUBSOLADOR EM FUNÇÃO DA ESTRUTURA, DO TEOR DE ARGILA E DE ÁGUA EM TRÊS LATOSSOLOS
}

\author{
Autor: CASSIANO MASSAKAZU SASAKI \\ Orientador: Prof. Dr. JOSÉ LEONARDO DE MORAES GONÇALVES
}

\section{RESUMO}

A rápida evolução tecnológica da silvicultura brasileira, verificada na década de 80, culminou com o sistema de cultivo mínimo do solo, implantado em grande escala a partir do início da década de 90. Levantamentos recentes junto a empresas florestadoras de expressão nacional, indicaram que cerca de $77 \%$ da área plantada é realizada no sistema de cultivo mínimo do solo. O amplo emprego do subsolador no cultivo mínimo e a falta de estudos científicos no projeto, o empirismo associado à operação e a falta de informações sobre a interação entre o teor de água e o tipo de solo subsolado motivaram a condução do presente estudo, cujos objetivos foram: (i) avaliar o desempenho operacional de um subsolador com haste parabólica em função da estrutura, do teor de argila e de água em três Latossolos, (ii) avaliar o grau de mobilização do solo em função de teores crescentes de argila e de água, (iii) avaliar a duração do efeito desagregador da subsolagem e a relação entre a área mobilizada de solo e o tempo póssubsolagem e, (iv) estabelecer um intervalo ideal de umidade para a subsolagem, em função da mobilização e da densidade máxima do solo. As pesquisas foram desenvolvidas em um Latossolo Vermelho Distrófico textura média (LVd-1), um Latossolo Vermelho Distrófico textura argilosa (LVd-2) e um Latossolo Vermelho Distrófico textura muito argilosa (LVd-3). A avaliação do desempenho operacional do 
subsolador foi realizada por meio dos parâmetros volume mobilizado de solo (VMS), profundidade efetiva de trabalho (PET), largura efetiva de trabalho (LET), velocidade média de deslocamento (VMD), capacidade teórica de trabalho (CTT) e rendimento (R). O grau de mobilização dos solos e o tempo de duração dos efeitos da subsolagem foram avaliados por meio da área mobilizada de solo (AMS), mensurada em três datas: logo após a subsolagem, 12 e 24 meses pós-subsolagem. O intervalo ideal de umidade para a subsolagem foi baseado na AMS e no teste de Proctor normal. A maioria dos parâmetros usados na avaliação do desempenho operacional indicou que teores de água mais baixos melhoram o desempenho do subsolador. Nos solos com estrutura em blocos, LVd-2, e com alto teor de argila, LVd-3, foram obtidos o maior VMS (com o solo mais seco) e o menor R (com o solo mais úmido); esses atributos também provocaram maior readensamento das partículas de solo no sulco de preparo, diminuindo o efeito desagregador da subsolagem mais rapidamente. Tanto no LVd-2, como no LVd-3, praticamente a metade da área mobilizada inicial foi modificada (56 e 49\%, respectivamente). O LVd-1 foi o solo que apresentou a menor resposta aos tratamentos, em função de sua capacidade de suporte ser mais estável que a dos outros Latossolos estudados. O LVd-1 apresentou melhores condições de ser subsolado entre os teores de água de 0,07 a $0,13 \mathrm{~cm}^{3} \mathrm{~cm}^{-3}$, o LVd-3, entre 0,14 a $0,27 \mathrm{~cm}^{3} \mathrm{~cm}^{-3}$ e, o LVd-2, apresentou a amplitude de subsolagem mais restrita, entre 0,12 a $0,19 \mathrm{~cm}^{3} \mathrm{~cm}^{-3}$.

Palavras-chave: subsolagem, cultivo mínimo, preparo de solo, re-adensamento. 


\title{
OPERATIONAL PERFORMANCE OF A SUBSOILER AS A FUNCTION OF THE STRUCTURE, CLAY AND MOISTURE CONTENT IN THREE \\ LATOSOLS
}

\author{
Author: CASSIANO MASSAKAZU SASAKI \\ Adviser: Prof. JOSÉ LEONARDO DE MORAES GONÇALVES
}

\section{SUMMARY}

The fast technological development of the Brazilian silviculture, during the 80's decade, culminated with the soil minimum cultivation system, established in large degree from the beginning of the 90's decade. Recent surveys in expressive Brazilian forest companies, indicated that about $77 \%$ of the planted area is accomplish under the soil minimum cultivation system. The large use of the subsoiler in the minimum cultivation, the empiricism associated to the operation and the lack of information about the interaction between the moisture content and the subsoiled soil motivated the present study, which objectives were: (i) evaluate the operational performance of a subsoiler with parabolic tine as a function of the soil structure, clay and moisture content of three Latosols, (ii) evaluate the soil disturbance degree as a function of the increasing on the clay and moisture content, (iii) evaluate the length of the subsoiling effect on the soil and the relationship between the soil disturbed area and the time after the subsoiling and, (iv) settle an ideal water interval to the subsoiling, as a function of the soil disturbance and the maximum bulk density. The researchers were developed in a sandy clay loam dystrophic Red Latosol (LVd-1), a clay dystrophic Red Latosol with kaolinit (LVd-2) and a clay dystrophic Red Latosol (LVd-3). The operational performance evaluation was 
realized by the parameters soil disturbed volume (SDV), work depth (WD), work width (WW), average speed (AS), theoretical work capacity (TWC) and efficiency (E). The soils disturbance degree and the length of the subsoiling effects were evaluated by the soil disturbed area (SDA), which was measured three times: after the subsoiling, 12 and 24 months after the subsoiling. The ideal water interval of the subsoiling was based upon the SDA and the normal Proctor's test. Most of the parameters used to the operational performance evaluation indicated that lower moisture contents improve the subsoiler performance. The soils with structure in blocks, LVd-2, and high clay content, LVd-3, presented higher SDV (when the soils were dryer) and lower E (when the soils were damper); these characteristics provoked high age-hardening of the soil particles either, decreasing the subsoiling effect faster. Almost half of the original soil disturbed area was modified in the LVd-2 and in the LVd-3 (56 and 49\%, respectively). The LVd-1 was the soil that presented the lower effect to the treatments, as a function of its high stability. The LVd-1 presented better conditions to be subsoiled between the moisture contents of 0,07 and $0,13 \mathrm{~cm}^{3} \mathrm{~cm}^{-3}$, the LVd-3, between 0,14 and $0,27 \mathrm{~cm}^{3} \mathrm{~cm}^{-3}$ and, the LVd-2, presented the lower subsoiling water range, between 0,12 and $0,19 \mathrm{~cm}^{3} \mathrm{~cm}^{-3}$.

Keywords: subsoiling, minimum cultivation, tillage, age-hardening. 


\section{INTRODUÇÃO}

O preparo de solo compreende um conjunto de práticas que, quando usadas racionalmente, podem manter ou elevar os índices de produtividade, a médio e longo prazo, reduzir a erosão hídrica e eólica, e melhorar a relação custo benefício dos recursos disponíveis: mão-de-obra, máquinas e implementos, combustíveis e insumos. Inadequadamente usadas, as técnicas de preparo podem degradar física, química e biologicamente o solo em poucos anos de uso, reduzindo seu potencial hídrico (Gonçalves et al., 2000; Gonçalves et al., 2002; Stape et al., 2002).

Os métodos de cultivo do solo florestal geralmente são agrupados em duas classes: cultivo intensivo e cultivo mínimo do solo. O cultivo intensivo do solo contempla amplo revolvimento de suas camadas superficiais, com incorporação total ou parcial dos resíduos culturais. Neste método, podem ser usados como implementos de preparo de solo o arado, o arado reformador, a grade leve e pesada, a grade "bedding”, dentre outros. O cultivo mínimo do solo prevê a realização de um preparo localizado apenas na linha ou na cova de plantio, sendo que a subsolagem e o coveamento são as principais operações de preparo de solo desse sistema (Gonçalves et al., 2000). O cultivo mínimo do solo foi implantado em larga escala a partir do início da década de 90, em função de pesquisas que trouxeram novas informações a respeito das interações entre a floresta e o solo, além de novos implementos e tratores florestais que foram adquiridos pelas empresas florestadoras nacionais. (Gava, 2002; Gonçalves, 2002b). 
Algumas pesquisas indicam que o teor de água e o tipo de solo são as variáveis edáficas que mais influem nas operações de preparo de solo (Baver et al., 1972; Cassel, 1979; McKyes, 1985; Srivastava et al, 1993). Em geral, solos com teores de água elevados geram menor demanda por força de tração, apesar de não serem mobilizados adequadamente (Beltrame, 1983; Rípoli et al., 1985; Sasaki et al., 2002). Teores de argila elevados, presença de argilas 2:1 e 1:1, camadas de adensamento natural e horizonte B mais superficial são algumas das características do solo que alteram o trabalho eficiente de um subsolador (Garner et al., 1987; Stafford (1979); Stape et al., 2002). O amplo emprego do subsolador no cultivo mínimo, o empirismo associado à operação e a falta de informações sobre a interação entre o teor de água e o tipo de solo subsolado motivaram a condução deste estudo.

Os objetivos deste estudo foram: (i) avaliar o desempenho operacional de um subsolador de haste parabólica em função da estrutura, do teor de argila e de água em três Latossolos, (ii) avaliar o grau de mobilização do solo em função de teores crescentes de argila e de água, (iii) avaliar a duração do efeito desagregador da subsolagem e a relação entre a área mobilizada de solo e o tempo pós-subsolagem, e, (iv) estabelecer um intervalo ideal de umidade para a subsolagem, em função da mobilização e da densidade máxima do solo. 


\section{REVISÃO DE LITERATURA}

\subsection{O cultivo mínimo do solo}

Os plantios florestais da década de 60 seguiam os sistemas de preparo de solo existentes para a agricultura, que previam o amplo revolvimento do solo com arados e grades. Esse sistema perdurou por mais de duas décadas e, de certo modo, impulsionou a silvicultura nacional. No entanto, ao longo desse período, observaram-se vários aspectos negativos nesse sistema de preparo, relacionados, principalmente, com a conservação do solo, o que colocava em risco a sustentabilidade de todo o sistema florestal (Gonçalves et al., 2000).

A grade bedding foi introduzida no início da década de 80, trazendo avanços importantes do ponto de vista operacional e de conservação do solo (Simões et al., 1981). Esse equipamento reduziu o revolvimento do solo e possibilitou o re-alinhamento em nível das linhas de plantio e a realização do preparo de solo conjuntamente à adubação de base.

Paralelamente, pesquisas evidenciaram que as interações entre a floresta e o solo eram bastante diferentes dos modelos propostos para os sistemas agrícolas. Tal diferenciação permitiu o estudo e a implementação de novas técnicas de preparo de solo, gerando, no início da década de 90, o sistema de cultivo mínimo do solo (Zen et al., 1995). O manejo dos resíduos culturais, a alteração física do solo, a dinâmica nutricional 
do sistema solo-planta e o manejo da água foram, então, reavaliados, pois vários estudos mostraram que as recomendações do preparo de solo deveriam ser embasadas nas características da planta, do solo, do clima e dos novos equipamentos utilizados (Stape et al., 2002).

Em 2002, levantamentos realizados junto a empresas florestadoras de expressão nacional, indicaram que cerca de $77 \%$ de suas áreas eram plantadas no sistema de cultivo mínimo. Nessas áreas, o preparo de solo é realizado predominantemente pela subsolagem e pelo coveamento, manual ou mecânico (Gonçalves et al., 2002).

O cultivo mínimo do solo consiste em revolvê-lo o mínimo necessário, mantendo os resíduos culturais sob o solo. Em plantações florestais, o preparo de solo é localizado apenas na linha ou na cova de plantio. O volume de solo revolvido é bem menor do que aquele realizado para culturas anuais, devido ao espaçamento de 2,5 a 3,5 m entre as linhas de plantio (Gonçalves et al., 2000; Gonçalves et al., 2002).

Para Gonçalves et al. (2000), o cultivo mínimo do solo apresenta algumas vantagens e desvantagens, se comparado ao cultivo intensivo. Suas principais vantagens são: (i) mantém ou melhora as características físicas do solo, (ii) reduz as perdas de nutrientes do ecossistema, (iii) mantém ou eleva a atividade biológica do solo, (iv) reduz a infestação de plantas invasoras, (v) reduz as despesas de implantação e reforma (replantio) de povoamentos florestais e, (vi) aumenta a flexibilidade no planejamento das atividades de preparo de solo. Dentre as desvantagens do cultivo mínimo do solo, são citadas a heterogeneidade do crescimento inicial dos povoamentos florestais e a maior dificuldade de proteção e manejo da floresta. 


\subsection{Definição de subsolagem e subsoladores}

Apesar de existirem diversas opções para se realizar o preparo primário do solo, a subsolagem se consolidou na área florestal devido aos seus efeitos benéficos para as plantas e às suas vantagens operacionais (maior capacidade de trabalho) e econômicas (menor custo) (Sasaki et al., 2002).

Nichols \& Reaves (1958) definem a subsolagem como uma operação de preparo de solo realizada normalmente entre 0,30 e $0,40 \mathrm{~m}$ de profundidade. A American Society of Agricultural Engineers, ASAE (1982), caracterizou a subsolagem como sendo uma cinzelagem ${ }^{2}$ profunda, abaixo de $0,40 \mathrm{~m}$, com o propósito de desestruturar o solo, melhorando o crescimento das raízes em profundidade.

Para Srivastava et al. (1993), a subsolagem é utilizada para romper camadas de solo impermeáveis ou compactadas, promovendo a infiltração da água. Para realizar tal operação, são empregados os subsoladores, caracterizados por hastes operadas em profundidades de 0,45 a 0,75 m, ou mais, promovendo pouca mistura e nenhuma inversão de solo. Nichols \& Reaves (1958) esclarecem que a subsolagem é realizada normalmente entre as profundidades de 0,30 a 0,40 m mas, em alguns casos, pode atingir até $0,60 \mathrm{~m}$.

A subsolagem pode alcançar profundidades de até 1,10 m nas áreas florestais do Litoral Norte da Bahia, com presença de adensamentos naturais (fragipãs e duripãs). Nesse caso, são utilizados subsoladores de haste simples, munidos de ponteiras com asas e tracionados por tratores de esteira D8 (Stape et al., 2002).

\footnotetext{
${ }^{2}$ Operação na qual uma ferramenta estreita rompe camadas adensadas do solo em profundidades de até 0,40 m, segundo definição da ASAE (1982).
} 
Para Balastreire (1987), os subsoladores são implementos utilizados sob a superfície do solo, com o intuito de desagregar suas camadas compactadas, facilitando a penetração de raízes e da água para camadas mais profundas. Os subsoladores requerem alta potência para sua utilização, pois podem trabalhar em profundidades de até $0,80 \mathrm{~m}$. McKyes (1985) definiu o subsolador como um tipo de arado cinzel, porém de construção mais resistente e rígida, utilizado para operar em profundidades de 0,40 a $0,90 \mathrm{~m}$.

Balastreire (1987) explica que os subsoladores são constituídos de:

- barra porta-ferramentas - montada no sistema hidráulico de levantamento dos tratores, ou de arrasto, se possuir uma barra de tração para acoplar no trator;

- haste - constituída de uma barra de aço plana, com formato variável de acordo com o fabricante. Normalmente o formato da haste é reto-inclinado, curvo ou parabólico. Como a haste é o principal elemento do subsolador, seu formato tem grande influência na força de tração demandada pela operação;

- ponteira - elemento acoplado à ponta da haste, que se desloca sob a superfície do solo. A ponteira desagrega determinado volume de solo à sua frente, que é determinado pelo teor de água em que o solo se encontra no momento da subsolagem;

- rodas de controle de profundidade - utilizadas caso o subsolador seja de arrasto, podendo ser de metal ou com roda e pneu.

Para Gadanha Júnior et al. (1991) e Rípoli et al. (1985), a subsolagem somente deve ser empregada se houverem situações de ordem física impedindo o armazenamento, disponibilidade de água e aeração do solo. Esses fatores podem impedir o desenvolvimento normal do sistema radicular se estiverem inadequados. 
A subsolagem é uma técnica utilizada para romper camadas de solo que tenham sofrido compactação ou, mesmo, perfis de solo mais densos. O rompimento das camadas compactadas traz benefícios imediatos, como a diminuição da resistência do solo à penetração das raízes e o aumento no volume dos macroporos. Esses benefícios melhoram a aeração e a drenagem interna do solo, pois permitem que o fluxo vertical da água seja mais rápido, provocando menores taxas de escoamento superficial e tempo de encharcamento do solo (Cassel, 1979; Taylor \& Beltrame, 1980).

Rípoli et al. (1985) afirmam que a principal função da subsolagem é o rompimento das camadas de solo adensadas. Esse rompimento provoca maior velocidade de infiltração da água, facilita a penetração do sistema radicular, melhora as trocas gasosas, melhora a drenagem e diminuí a erosão superficial do solo. Na área florestal, a subsolagem, muitas vezes, não possui a premissa de romper as camadas de solo adensadas, mas sim a de afofá-lo na linha de plantio, de modo a facilitar a abertura de covas e agilizar o crescimento das raízes em profundidade (Sasaki et al., 2002).

\subsection{Avaliação do desempenho operacional de subsoladores}

Gamero \& Lanças (1996) citam algumas variáveis que podem ser mensuradas para se avaliar o desempenho operacional de máquinas de mobilização periódica do solo. Dentre eles estão: largura de corte (teórica, efetiva e operacional), velocidade de deslocamento, força de tração, consumo horário de combustível, consumo específico operacional, consumo de combustível por área trabalhada, patinagem das rodas motrizes, resistência específica operacional e capacidade de campo efetiva.

Para se avaliar o desempenho operacional corretamente, Balastreire (1987), Gadanha Júnior et al. (1991), Gamero \& Lanças (1996) e Srivastava et al. (1993) afirmam que se deve ter conhecimento suficiente sobre as características do solo 
trabalhado, tais como a compactação existente, o teor de água, a cobertura existente na superfície, a textura e a estrutura, além das características necessárias para operar o equipamento adequadamente, como a profundidade de trabalho, o espaçamento entre hastes, a potência necessária, as dimensões e os formatos das hastes.

Ao avaliar um subsolador com haste parabólica, nas profundidades de 0,30, 0,40 e 0,50 m, Bicudo (1990) verificou que as subsolagens realizadas a 0,50 m de profundidade provocaram aumento na força de tração, no consumo horário de combustível e na resistência específica operacional. Por outro lado, essa profundidade provocou valores menores de área útil trabalhada e de capacidade de campo efetiva. O estudo foi conduzido em um Nitossolo Vermelho de textura muito argilosa (650 g kg-1 de argila).

Beltrame (1983) avaliou o desempenho operacional de três subsoladores (hastes reta-inclinadas a 21, 26 e $45^{\circ}$ ) em um Latossolo Vermelho de textura argilosa (496 g kg-1 de argila). O pesquisador avaliou os subsoladores por meio das variáveis velocidade de deslocamento, consumo de combustível, capacidade efetiva de campo e área mobilizada de solo. Os resultados mostraram que a subsolagem foi mais eficiente ao ser executada em teores de água abaixo do limite inferior de plasticidade e o subsolador mais eficiente foi o de haste reta-inclinada a $21^{\circ}$.

O estudo conduzido por Lanças (1988), em um Nitossolo Vermelho de textura muito argilosa (650 g kg-1 de argila), permitiu concluir que a resistência e o consumo específicos operacionais, a capacidade de campo efetiva e o consumo de combustível por área trabalhada foram as variáveis mais eficientes para analisar o desempenho de três tipos de hastes (duas parabólicas e uma reta-inclinada) e duas ponteiras (com e sem asas). Além dessas variáveis, o pesquisador também contemplou o empolamento, a largura de corte, a profundidade, a área e o volume mobilizado de solo, a força de tração, a potência na barra de tração e a patinagem das rodas motrizes. 


\subsection{Efeitos do teor de água e do tipo de solo na subsolagem}

O teor de água no solo é uma das variáveis que mais influi na subsolagem, fato decorrente da coesão entre as partículas do solo. Em teores de água baixos, o solo é mais coeso, devido à cimentação entre suas partículas secas. Em muitos casos, até mesmo grandes torrões podem ser gerados, caso o solo seja subsolado nessa condição (Baver et al., 1972). À medida que o solo umedece, moléculas de água são adsorvidas na superfície de suas partículas, diminuindo a coesão. Quanto maior a superfície de contato das partículas, maior o filme de água adsorvido e, portanto, menor a coesão do solo. Caso o teor de água no solo seja muito elevado, as operações de preparo se tornam praticamente ineficazes, devido ao efeito lubrificante da água (Rosa Júnior, 2000; Silva et al., 2002a).

Nichols \& Reaves (1958) afirmam que a subsolagem não é recomendada caso o solo esteja muito úmido, pois ele pode fluir plasticamente pela haste. Baver et al. (1972) e McKyes (1985) observaram que a propagação do cisalhamento do solo depende de sua coesão, de sua adesão e de seu ângulo de atrito. Sabendo-se que o teor de água do solo afeta significativamente esses parâmetros, a qualidade da subsolagem fica, portanto, dependente do teor de água no solo.

Para Cassel (1979), os solos que apresentam teores de água elevados exigem menos potência para tracionar o subsolador. No entanto, o solo, ao ser subsolado nessa condição, apresenta menor mobilização. O pesquisador ressalta que o ideal é subsolar os solos quando eles se encontram friáveis, o que geralmente implica em maior demanda por força de tração. Rípoli et al. (1985) concordam que a subsolagem é mais eficiente se realizada quando o solo apresenta teores de água mais baixos. Nessa condição, verificase maior mobilização do solo e menor risco de sua compactação com o tráfego do trator. 
Outros atributos edáficos que podem interferir na subsolagem são a textura, a presença de argilas do tipo 2:1 e 1:1, a estrutura e o teor de matéria orgânica. Esses atributos são inerentes a cada tipo solo e geram grande variabilidade na operação (McKyes, 1985). Pesquisas citadas por Baver et al. (1972) mostraram que existe alta correlação entre a coesão e o teor de argila dos solos. Os pesquisadores verificaram que a força de coesão para três solos com diferentes texturas (no mesmo teor de água) é de 2,3 g cm2 para um solo arenoso, 4,1 g cm2 para um solo de textura média e de 8,7 g cm2 para um solo muito argiloso.

Para Baver et al. (1972), a adsorção de água aos minerais de argila depende de sua superfície de contato e de sua plasticidade. O feldspato e o quartzo, sem nenhuma plasticidade, não adsorvem praticamente nenhuma molécula de água. Por outro lado, caulinita, talco, moscovita, biotita e outros minerais formados por placas, podem reter água. A ordem crescente de adsorção de moléculas de água, no estado gasoso, é: montmorilonita > ilita > caulinita. A capacidade de adsorção da montmorilonita chega a ser 15 vezes maior do que a da caulinita, em função da maior superfície de contato e da capacidade de orientação das moléculas de água.

A matéria orgânica exerce um efeito interessante na retenção de água pelo solo. Estudos realizados por Baver (1930) ${ }^{2}$, citado por Baver et al. (1972), mostraram que os horizontes mais superficiais dos solos retêm mais água do que os horizontes mais profundos, fato diretamente relacionado à quantidade de matéria orgânica. O pesquisador cita como exemplo o horizonte A de um solo, com 7,0 g kg-1 de matéria orgânica. Nesse caso, sua capacidade máxima de retenção de água foi de 52,2 cm3 cm-3. Em seguida, o solo teve sua matéria orgânica oxidada e, como resultado, reteve apenas 27,7 cm3 cm-3 de água.

\footnotetext{
${ }^{2}$ BAVER, L.D. The Atterberg consistency constants: factors affecting their values and a new concept of their significance. Journal of American Society of Agronomy, n.22, p.935-948, 1930.
} 
Os solos com estrutura em blocos, típicos dos solos cauliníticos, geralmente são mais coesos, principalmente em teores de água baixos. Nesses solos, o grau da estrutura é forte, caracterizados por agregados individuais unidos fracamente por substâncias cimentantes. Os solos cauliníticos também são mais pegajosos, plásticos e mais resistentes à penetração, dependendo do teor de água em que se encontram, características que dificultam sua mecanização (Gonçalves, 2002a).

Garner et al. (1987) avaliaram a subsolagem em cinco solos da Planície Costeira dos Estados Unidos. Os pesquisadores verificaram que o consumo de combustível, em relação à área mobilizada de solo, foi maior para os solos com camadas compactadas ou com horizonte B mais superficial. O estudo de Stafford (1979), em dois solos de texturas diferentes (arenosa e argilosa), evidenciou que a força de tração foi maior para o solo argiloso, principalmente quando ele se encontrava com teor de água mais baixo.

Yshimine (1993) avaliou o desempenho operacional de um subsolador com haste parabólica, em dois Latossolos Vermelhos (um de textura média, com 284 g kg-1 de argila, e outro de textura argilosa, com 484 g kg-1 de argila) e um Nitossolo Vermelho (textura argilosa, com 493 g kg-1 de argila). O pesquisador verificou que a área mobilizada de solo e a largura de corte foram maiores para os solos mais argilosos, apesar deles também terem apresentado maior demanda por força de tração.

Estudos de Bentivenha et al. (2003), conduzidos em um Neossolo Quartzarênico e em um Latossolo Vermelho Amarelo de textura média, mostraram que o tipo de solo influenciou significativamente o desempenho operacional de três subsoladores. Os pesquisadores verificaram que o Neossolo Quartzarênico apresentou melhores resultados que o Latossolo Vermelho Amarelo, para todas as variáveis avaliadas (profundidade e largura de trabalho, área e volume mobilizado de solo, área útil trabalhada, capacidade de campo efetiva e rompimento relativo de solo). 
Sasaki (2000) e Sasaki et al. (2002), avaliaram o desempenho operacional de três subsoladores (duas hastes parabólicas e uma reta-inclinada), em dois solos (Neossolo Quartzarênico, RQ, com 62 g kg-1 de argila e Latossolo Vermelho Amarelo, LVA, com 305 g kg-1 de argila) e em teores de água distintos (RQ com 0,045 e 0,057 cm3 cm-3 e LVA com 0,033 e 0,174 cm3 cm-3). Os pesquisadores utilizaram as variáveis força de tração, potência na barra de tração, velocidade de deslocamento, patinagem das rodas motrizes, resistência específica operacional, capacidade efetiva de trabalho, profundidade efetiva de trabalho e área mobilizada de solo para avaliar os três subsoladores. De modo geral, o RQ apresentou os melhores resultados operacionais, mesmo quando estava mais úmido. O LVA apresentou pior desempenho quando estava mais úmido, com valores mais baixos de velocidade de deslocamento, capacidade de trabalho e área mobilizada de solo.

\subsection{0 processo de re-adensamento do solo}

Para Horn \& Dexter (1989), a estruturação original do solo é um processo normalmente demorado. Apesar disso, os agregados desestruturados por implementos de preparo de solo geralmente se re-arranjam parcial ou totalmente durante um período de tempo mais curto. Esse efeito é conhecido por endurecimento (“age hardening”) ou readensamento (“strenght regain”). No caso do re-arranjo total das partículas, o processo é conhecido por tixotropia (Horn \& Dexter, 1989; Utomo \& Dexter, 1981).

Existem diversos mecanismos envolvidos no processo de re-adensamento do solo. Caso o solo seja mantido em teores de água constantes, são dois mecanismos principais: no primeiro, as partículas de solo se re-orientam em posições de mínimo gasto energético e, no segundo, a cimentação das partículas de solo ocorre nos pontos de contato mais próximos. Caso o teor de água varie, como geralmente ocorre no campo, a tensão entre as partículas aumenta quando o solo passa pelo processo de secagem, 
aproximando as partículas. A contração e a expansão dos colóides do solo é outro fator que implica no seu re-adensamento, uma vez que esses processos podem formar ou quebrar alguns pontos de contato entre as partículas do solo (Horn \& Dexter, 1989).

Horn \& Dexter (1989) explicam que o processo de re-adensamento ocorre da seguinte maneira: (A) durante a primeira secagem do solo mobilizado, a tensão exercida pelos meniscos de água aproximará as partículas umas das outras; (B) quanto mais seco, maior será a densidade do solo; (C) no umedecimento, os agregados perdem parte da tensão existente entre as partículas do solo, promovendo a distribuição dessas partículas de acordo com seu tamanho e forma; (D) com a nova distribuição das partículas e dos poros do solo, a massa de solo se torna mais homogênea.

Existem outros fatores que podem influir positiva ou negativamente no readensamento do solo, como a atividade macro e microbiológica, a presença de raízes, o teor de argila e de matéria orgânica, a lixiviação de partículas cimentantes, o fluxo de massa e o tráfego de máquinas (Cassel, 1979; Chaney \& Swift, 1986; Hénin, 1976; Kemper \& Rosenau, 1984; Richardson, 1976; Salih \& Maulood, 1988; Taylor \& Beltrame, 1980; Utomo \& Dexter, 1981; Utomo \& Dexter, 1982).

Os ciclos de umedecimento e secagem parecem ser os maiores responsáveis pela restruturação do solo, tanto nos perfis estruturados como nos mobilizados por equipamentos periódicos de preparo (Chaney \& Swift, 1986; Horn \& Dexter, 1989; Richardson, 1976; Utomo \& Dexter, 1982). Nos solos estruturados, os ciclos de umedecimento e secagem podem provocar tanto a desestruturação como a estruturação. Secagens muito intensas e umedecimentos muito rápidos favorecem a desestruturação do solo. Secagens graduais e umedecimentos lentos e constantes favorecem a estruturação. Os solos mobilizados por implementos periódicos de preparo são mais sujeitos ao re-adensamento, pois a secagem promove a atração entre suas partículas, enquanto que o umedecimento promove a lixiviação de substâncias cimentantes e o 
encrostamento (Baver et al., 1972; Chaney \& Swift, 1986; Richardson, 1976; Utomo \& Dexter, 1981; Utomo \& Dexter, 1982).

Oliveira (1992) estudou os efeitos de 20 ciclos de umedecimento e secagem em 4 Latossolos. O pesquisador verificou que esses ciclos promoveram a redução dos macroporos dos Latossolos cauliníticos, enquanto que nos Latossolos gibbsíticos isso não foi detectado. A estrutura em blocos angulares e sub-angulares, típica dos Latossolos cauliníticos (Ferreira, 1988), apresenta maior superfície de contato que a granular dos Latossolos gibbsíticos, o que leva à redução mais rápida do espaço poroso total. A estrutura granular, mais estável, não proporcionou redução dos macroporos, mesmo com o movimento de água devido ao umedecimento.

Existem informações contraditórias quanto à duração dos efeitos da subsolagem. Hénin (1976) acompanhou os efeitos da subsolagem em 22 solos. Após o período de 2 a 3 anos, apenas 8 solos ainda apresentavam os efeitos da operação. Nos outros 14 solos, o pesquisador observou apenas a presença de um canal com paredes lisas no local em que a haste subsoladora passou. Cassel (1979) observou que os solos do Meio Oeste americano apresentaram os efeitos da subsolagem pelo período de 1 ano. Nos outros solos da Planície Costeira do Atlântico esses efeitos perduraram por 2 anos.

Para Taylor \& Beltrame (1980), a subsolagem pode ter seu efeito perdurado em solos argilosos por até 4 anos, caso algumas condições ideais de operação, como o teor de água no solo, a velocidade de deslocamento, a profundidade de trabalho, o número de hastes e a potência do trator sejam observados. Silva et al. (1990) verificaram que os efeitos positivos da subsolagem perduraram por cerca de 1 ano. Após 2 anos de avaliação, as áreas subsoladas apresentavam características muito próximas das áreas que não haviam sido subsoladas. Essas observações mostram que a duração dos efeitos da subsolagem deve estar relacionada às condições físicas, morfológicas e mineralógicas dos solos. 


\section{MATERIAL E MÉTODOS}

\subsection{Locais}

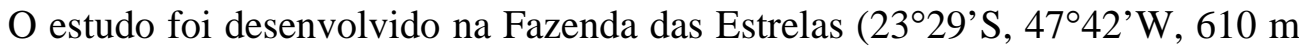
de altitude), localizada no Município de Alambari, SP, e na Fazenda Santa Rosa (2351’S, 4751’W, 715 m de altitude), localizada no Município de São Miguel Arcanjo, SP. Segundo a classificação de Köeppen, o clima da região de Alambari é do tipo Cfa, em que a temperatura média do mês mais quente (janeiro) é de 22 a $23^{\circ} \mathrm{C}$ e a do mês mais frio (julho) é de 15 a $16^{\circ} \mathrm{C}$; durante os 2 anos da pesquisa, a precipitação foi de 2825 mm. São Miguel Arcanjo apresenta clima do tipo Cfb, em que a temperatura média do mês mais quente (janeiro) é de 21 a $22^{\circ} \mathrm{C}$ e a do mês mais frio (julho) é de 14 a $15^{\circ} \mathrm{C}$; durante os 2 anos da pesquisa, a precipitação foi de $2792 \mathrm{~mm}$.

\subsection{Solos}

O solo da área experimental da Fazenda das Estrelas foi caracterizado como Latossolo Vermelho Distrófico textura média (LVd-1). Na Fazenda Santa Rosa, os solos das áreas experimentais foram caracterizados como Latossolo Vermelho Distrófico textura argilosa (LVd-2) e Latossolo Vermelho Distrófico textura muito argilosa (LVd3), segundo EMBRAPA (1999a). 


\subsection{Características morfológicas, físicas e químicas dos solos}

A caracterização dos óxidos (determinada pelo ataque sulfúrico), a textura (determinada pelo método da pipeta) e a densidade de partículas (determinada pelo método do picnômetro) foram realizadas segundo EMBRAPA (1997). A matéria orgânica foi determinada segundo EMBRAPA (1999b). Essas determinações foram realizadas em 48 amostras deformadas por solo, coletadas previamente à instalação do experimento nas camadas de 0 a 10, 10 a 20, 20 a 30 e 30 a $40 \mathrm{~cm}$. Algumas de suas características morfológicas, físicas e químicas são apresentadas na Tabela 1.

As análises físico-mecânicas dos solos foram realizadas em 24 amostras não deformadas para cada tipo de solo, que foram coletadas na profundidade de $20 \mathrm{~cm}$, em anéis com $50 \mathrm{~mm}$ de diâmetro por $50 \mathrm{~mm}$ de altura. Essas amostras, após serem saturadas com água, foram submetidas aos potenciais de -0,01 e -1,5 MPa, utilizando pressões aplicadas em câmaras com placas porosas, conforme Klute (1986). Cessada a drenagem e atingindo o equilíbrio hidráulico aparente, as amostras foram pesadas e, em seguida, secas em estufa a $\pm 105^{\circ} \mathrm{C}$, por 24 horas, para a determinação da densidade do solo (Blake \& Hartge, 1986).

\subsection{Trator}

O trator utilizado para tracionar o subsolador era da marca Valtra, modelo 985S, equipado com motor de aspiração forçada de quatro cilindros, quatro tempos, potência de 77 kW (105 cv) a 2300 rpm e torque de 390 Nm a 1400 rpm. A capacidade máxima de levante do sistema hidráulico era de 25408 N (2590 kgf) a 610 mm do olhal. Durante as avaliações foi empregada a marcha $2 \mathrm{H}$ (segunda marcha rápida), com a 
Tabela 1. Alguns atributos físicos, químicos e morfológicos da camada 0 a $40 \mathrm{~cm}$ dos solos

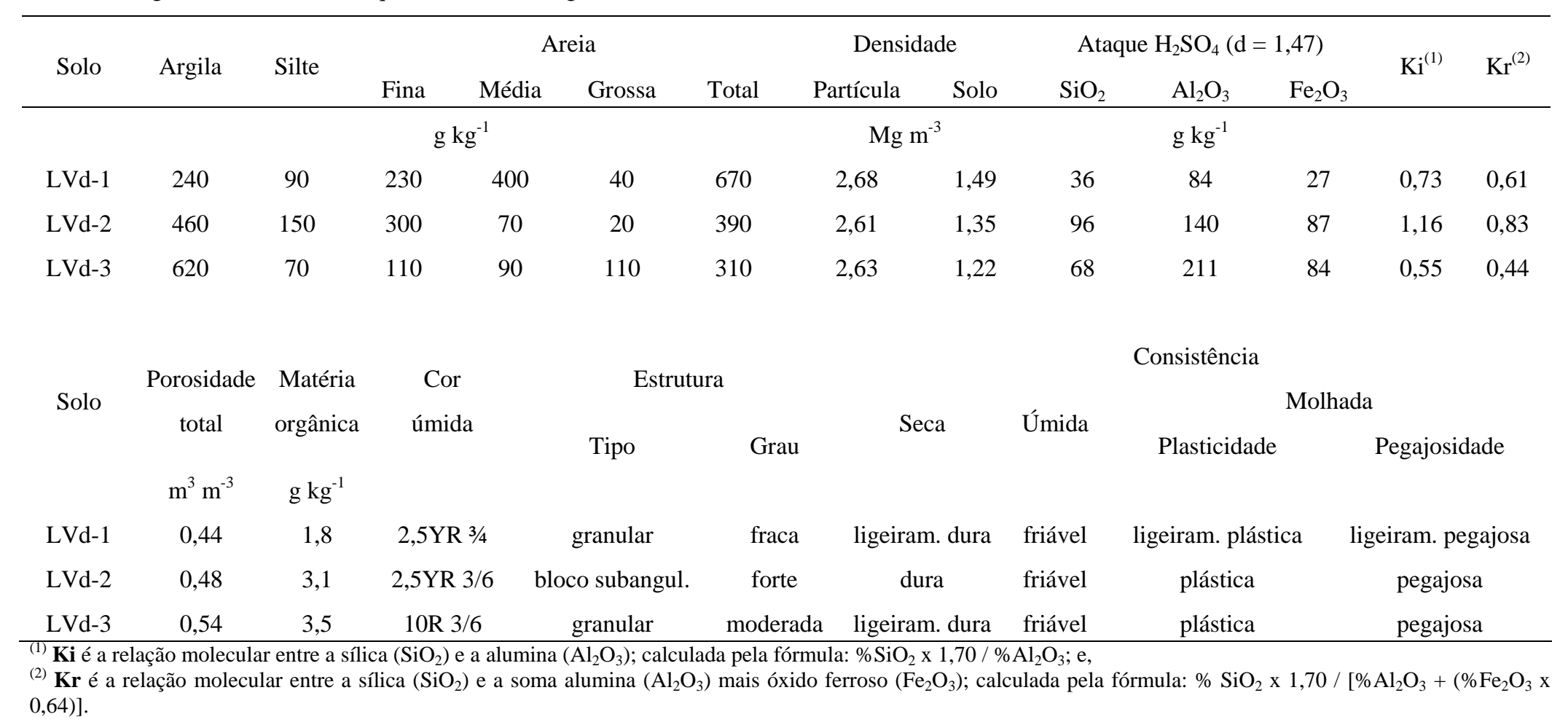


tração dianteira auxiliar (TDA) acionada e rotação do motor fixada em 2500 rotações por minuto.

\subsection{Haste subsoladora e ponteira}

O subsolador avaliado foi de haste única, acoplado ao sistema hidráulico de três pontos do trator, com controle de profundidade por braçadeira de fixação. A configuração da haste subsoladora era parabólica e representada pela equação $f(x)=1,881-0,163 \cdot x+0,091 \cdot x^{2}$ (Figura 1). A ponteira do subsolador possuía largura de 6,5 cm (Figura 1), o que habilita o trabalho em profundidades de 32,5 a 45,5 cm, pois se considera que a profundidade ideal de trabalho deve ser de 5 a 7 vezes a largura da ponteira (Spoor \& Godwin, 1978).

\subsection{Tratamentos experimentais}

Os tratamentos experimentais consistiram em realizar as subsolagens entre a capacidade de campo (CC) e o ponto de murcha permanente (PMP). Em cada tipo de solo foram realizadas subsolagens em cinco níveis de teor de água, encontrados no campo após diferentes períodos de estiagem (Tabela 2). No momento de cada subsolagem foram coletadas 48 amostras de solo deformadas para determinação de seu teor de água, pelo método gravimétrico (EMBRAPA, 1997). O delineamento experimental foi o de parcelas subdivididas, com quinze tratamentos ( 3 solos vezes 5 níveis de teor de água) e quatro repetições. 

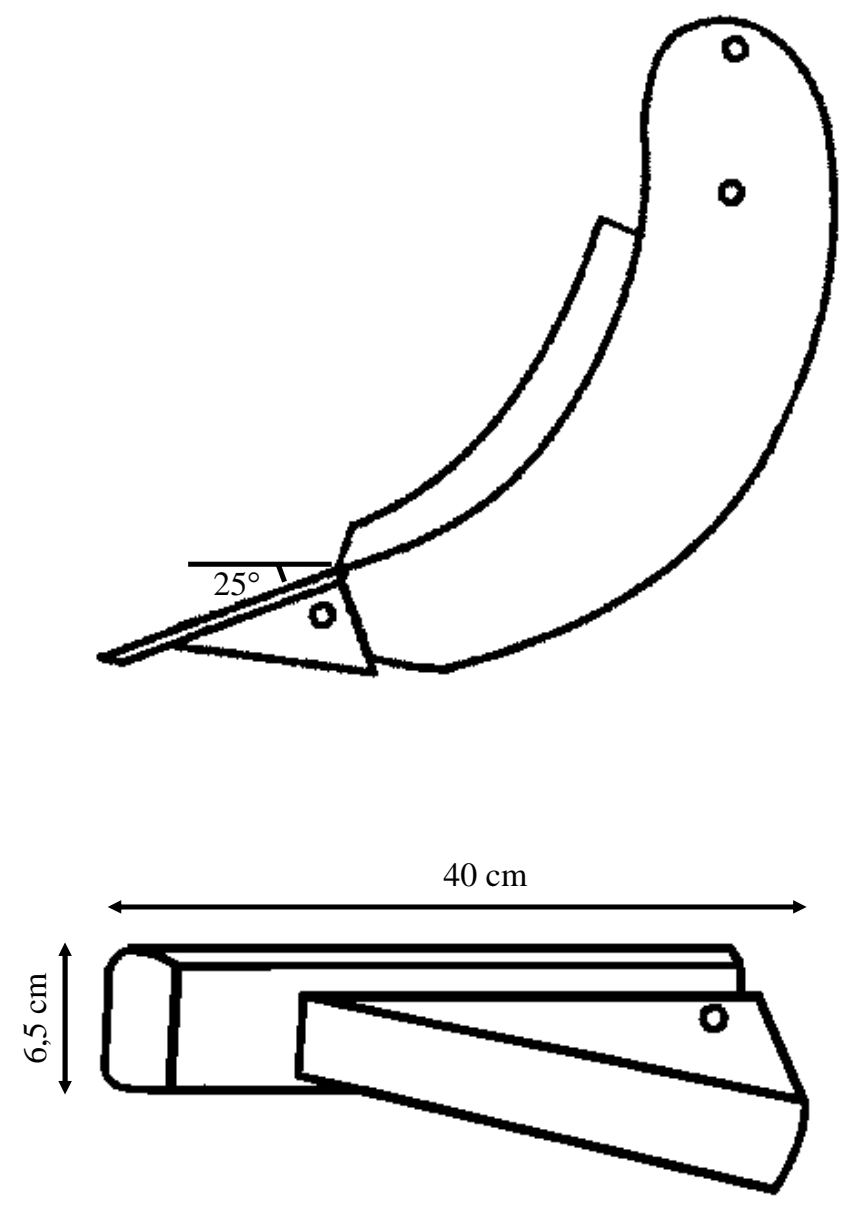

Figura 1 - Haste parabólica e dimensões da ponteira sem asas do subsolador

Tabela 2. Teores de água na capacidade de campo (CC, -0,01 MPa), no ponto de murcha permanente (PMP, -1,5 MPa) e por ocasião das subsolagens em cada tipo de solo estudado

\begin{tabular}{cccccccc}
\hline Solo & CC & PMP & $1^{\mathrm{a}}$ & $2^{\mathrm{a}}$ & $3^{\mathrm{a}}$ & $4^{\mathrm{a}}$ & $5^{\mathrm{a}}$ \\
\hline & \multicolumn{7}{c}{$\mathrm{cm}^{3} \mathrm{~cm}^{-3}$} \\
LVd-1 & 0,17 & 0,07 & 0,079 & 0,087 & 0,102 & 0,115 & 0,143 \\
LVd-2 & 0,23 & 0,12 & 0,127 & 0,152 & 0,161 & 0,177 & 0,213 \\
LVd-3 & 0,34 & 0,14 & 0,151 & 0,192 & 0,227 & 0,273 & 0,322 \\
\hline
\end{tabular}


Cada parcela experimental tinha $60 \mathrm{~m}^{2}, 20 \mathrm{~m}$ de comprimento por $3 \mathrm{~m}$ de largura. Antes de cada parcela, foram reservados 15 m para a estabilização da velocidade de trabalho e profundidade de operação do subsolador. Outros 15 m após a parcela foram usados para manobras e outras operações. Os dados foram submetidos, quando conveniente, à análise estatística descritiva, à análise de variância (ANOVA) e à análise de regressão, todas ao nível de 5\% de probabilidade. Os programas estatísticos usados nas análises foram o Sigmaplot (2002) e o Statgraphics Plus for Windows (1995).

\subsection{Avaliação do desempenho operacional do subsolador}

O desempenho operacional do subsolador foi avaliado pelos parâmetros volume mobilizado de solo por hectare, profundidade e largura efetiva de trabalho, velocidade de deslocamento, capacidade teórica de trabalho do conjunto tratorimplemento e rendimento. O volume mobilizado de solo por hectare foi determinado baseado no espaçamento de três metros entre as linhas de plantio, de acordo com a equação:

$\mathrm{VMS}=\mathrm{AMS} \times \frac{10.000}{\mathrm{~L}}$

em que, VMS = Volume Mobilizado de Solo, $\mathrm{m}^{3} \mathrm{ha}^{-1}$, AMS = Área Mobilizada de Solo, $\mathrm{m}^{2}$ e $\mathrm{L}=$ Espaçamento entre Linhas de Plantio.

A área mobilizada de solo foi avaliada pelo método das zonas de resistência (Bentivenha et al., 2003; Stape et al., 2002). Inicialmente, antes da subsolagem, fez-se a avaliação da resistência à penetração do solo em condições naturais com uso de um penetrômetro de impacto (Stolf et al., 1982). Após a subsolagem, com o mesmo penetrômetro, em três transectos por parcela experimental, perpendiculares à linha 
central de subsolagem, foi avaliada a resistência à penetração do solo resultante dessa operação. Esses transectos possuíam largura total de $90 \mathrm{~cm}, 45 \mathrm{~cm}$ à esquerda e $45 \mathrm{~cm}$ à direita da linha central. As sondagens foram feitas a cada 15cm (Figura 2). A AMS foi considerada como toda porção de solo que apresentou resistência à penetração menor do que a resistência à penetração obtida antes da subsolagem. No exemplo da Figura 2, a resistência à penetração do solo obtida antes da subsolagem foi de 2,4 MPa, num teor de água de $0,227 \mathrm{~cm}^{3} \mathrm{~cm}^{-3}$. A área mobilizada de solo foi, portanto, a porção de solo que apresentou resistência à penetração inferior a este valor, destacada na Figura 2. As isolinhas com resistência à penetração maior do que a isolinha de 2,4 MPa foram resultantes do deslocamento de solo causado pela passagem do subsolador (Nichols et al., 1958). A profundidade (PET) e a largura efetiva de trabalho (LET) foram geradas pelas figuras da AMS (Figura 2). A LET foi determinada aos $5 \mathrm{~cm}$ de profundidade em função da baixa resistência à penetração observada na camada de solo de 0 a $5 \mathrm{~cm}$ de profundidade.

A velocidade média de deslocamento do conjunto trator/implemento foi avaliada de modo indireto, dividindo-se o tamanho da parcela experimental pelo tempo de percurso, medido por cronômetro. Foram realizadas quatro repetições por coleta de dados, usando-se a seguinte equação:

$\mathrm{VMD}=\frac{\mathrm{S}}{\mathrm{t}} \times 3,6$

em que, $\mathrm{VMD}$ = velocidade média de deslocamento, $\mathrm{km} \mathrm{h}^{-1}, \mathrm{~S}=$ espaço percorrido na parcela, $20 \mathrm{~m}$, e t = tempo gasto no percurso, s.

A capacidade teórica de trabalho foi obtida por meio da seguinte equação:

$\mathrm{CTT}=\frac{\mathrm{VMD} \times \mathrm{L}}{10.000}$ 
em que, CTT = capacidade teórica de trabalho, ha $\mathrm{h}^{-1}, \mathrm{VMD}=$ velocidade média de deslocamento, $\mathrm{km} \mathrm{h}^{-1}$ e L = Espaçamento entre Linhas de Plantio.

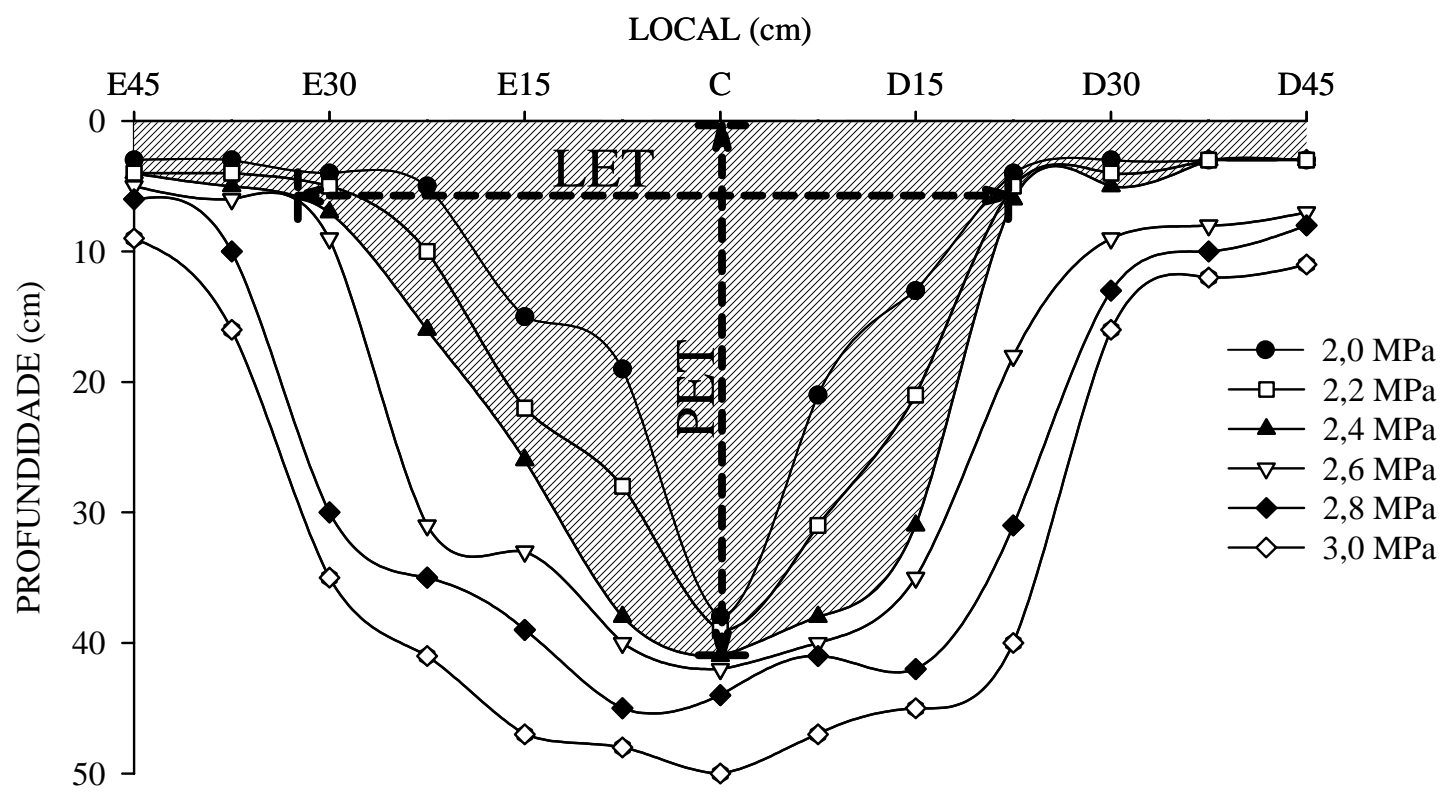

Figura 2 - Exemplo ilustrativo de isolinhas de resistência à penetração do solo, obtidas pelo penetrômetro de impacto. No eixo $\mathrm{X}$, o ponto $\mathrm{C}$ está localizado na linha central de subsolagem e, os demais, à esquerda e à direita, à distância de $15 \mathrm{~cm}$ um do outro. A área em destaque é delimitada pela isolinha que corresponde à resistência à penetração antes da subsolagem (2,4 MPa), portanto, designa a área mobilizada de solo pela subsolagem (AMS). Em tracejado, a determinação da profundidade (PET) e da largura efetiva de trabalho (LET), pelo método das zonas de resistência

O rendimento da subsolagem, foi avaliado por meio da seguinte equação:

$\mathrm{R}=\frac{\text { tempo do percurso sem realizar a subsolagem }}{\text { tempo do percurso realizando a subsolagem }} \times 100$

em que, $\mathrm{R}=$ rendimento, $\%$. 
A obtenção do tempo de percurso sem realizar a subsolagem foi realizada por cronômetro, em áreas planas com o mesmo comprimento das parcelas (20 m). Nessas áreas o trator também foi mantido em segunda marcha rápida $(2 \mathrm{H})$, com a tração dianteira auxiliar (TDA) acionada e a rotação do motor fixada em 2500 rotações por minuto. Foram realizadas quatro repetições por coleta de dados.

\subsection{Avaliação do re-adensamento do sulco de preparo}

A avaliação do re-adensamento do sulco de preparo foi baseada na área mobilizada de solo, mensurada em três épocas: logo após a subsolagem, aos 12 e aos 24 meses pós-subsolagem. Após a avaliação inicial (logo após a subsolagem), as parcelas experimentais foram isoladas para se evitar o tráfego de máquinas sobre os sulcos e o plantio de mudas no local. Os teores de água no solo, por ocasião das avaliações, foram 0,102; 0,111 e 0,106 $\mathrm{cm}^{3} \mathrm{~cm}^{-3}$ (LVd-1), 0,177; 0,165 e 0,171 $\mathrm{cm}^{3} \mathrm{~cm}^{-3}$ (LVd-2) e 0,227; 0,216 e $0,225 \mathrm{~cm}^{3} \mathrm{~cm}^{-3}$ (LVd-3), respectivamente aos 0, 12 e 24 meses pós-subsolagem.

\subsection{Ensaio de Proctor normal}

A maior compactação possível do solo foi avaliada pelo ensaio de Proctor normal, que promove um meio de se determinar o teor de água no qual uma certa quantidade de energia irá compactar o solo no seu estado mais denso (máxima densidade do solo). Foram coletados aproximadamente $20 \mathrm{~kg}$ de cada tipo de solo (cada repetição do teste de Proctor consome cerca de 2,5 a 3,0 kg desse material), na camada de 10 a 30 $\mathrm{cm}$, com o auxílio de um trado. As amostras de solo foram secas em estufa a $40^{\circ} \mathrm{C}$ por 24 horas. Após a secagem, essas amostras foram peneiradas em malhas de $2 \mathrm{~mm}$. Em seguida, pesou-se a matriz do teste de Proctor e umedeceu-se uma das amostras (3,0 kg 
de solo). Adicionou-se 1/3 de solo umedecido à matriz e compactou-se esse volume com 25 impactos em padrão concêntrico. Adicionou-se o segundo terço de solo e repetiu-se a compactação. Adicionou-se o terceiro terço e repetiu-se a compactação. Após essas etapas, o colar de contenção da matriz foi removido, efetuando-se o acabamento e limpeza do conjunto matriz + solo compactado, que foram pesados novamente. Parte desse solo foi retirada para determinação do teor de água e o restante foi umedecido novamente para repetir-se todo o processo. O momento em que a massa do conjunto matriz + solo compactado começa a decrescer, indica o teor de água em que ocorre a máxima densidade do solo (método adaptado de Stancati et al., 1981). 


\section{RESULTADOS E DISCUSSÃO}

\subsection{Desempenho operacional do subsolador}

O volume mobilizado de solo (VMS) e o teor de água apresentaram relação inversa para os três Latossolos (Figura 3). Verificou-se que quanto menor era o teor de água, maior era o VMS. Isso pode ser atribuído à maior força de coesão entre as partículas do solo, pois em baixos teores de água a coesão é maior (Baver et al., 1972; Silva et al., 2002a). Nichols et al. (1958), afirmam que quanto mais coeso o solo, mais eficiente é a propagação dos efeitos da subsolagem nos seus planos de cisalhamento (à frente, acima e lateralmente à haste subsoladora). Outro fator que deve ser considerado é o efeito lubrificante da água, que é reduzido quando o solo está mais seco, proporcionando maior mobilização (Rosa Júnior, 2000; Silva et al., 2002a). Sasaki et al. (2002) e Bentivenha et al. (2003) verificaram o mesmo efeito num Latossolo VermelhoAmarelo textura média (340 $\mathrm{g} \mathrm{kg}^{-1}$ de argila), em dois teores de água $\left(0,03\right.$ e $0,17 \mathrm{~cm}^{3}$ $\left.\mathrm{cm}^{-3}\right)$.

O LVd-2 foi o solo que, na média, apresentou maior mobilização (Figura 3). Isso pode ter ocorrido devido à estrutura em blocos deste solo (rico em caulinita), conseqüentemente, mais coeso. O LVd-3, de textura fina e estrutura moderada granular, apresentou maior mobilização que o LVd-1, de textura mais grossa e estrutura fraca granular (Tabela 1). A maior coesão dos solos de textura fina (quando secos) é a razão mais plausível para explicar esses resultados (Baver et al., 1972; Gonçalves, 2002a). 
Não houve nenhuma tendência de dispersão dos dados em função do aumento do teor de água nos solos e, no geral, a variação foi aceitável. O maior coeficiente de variação (CV) para o VMS foi de 8,7\%, observado no LVd-3, e o menor CV foi de 2,2\%, observado no LVd-2.

A profundidade efetiva de trabalho (PET), mensurada nos perfis de solo gerados pelo método das zonas de resistência, apresentou relativamente baixa variabilidade (Figura 3), apesar de ser considerada uma operação variável (Bicudo, 1990; Lanças, 1988; Sasaki et al., 2002; Yshimine, 1993). Isso pode ter ocorrido por 3 razões principais: i) houve uma regulagem rigorosa do equipamento, realizando-se vários testes de profundidade em locais adjacentes às áreas experimentais, até se atingir os $40 \mathrm{~cm}$ propostos; ii) as áreas experimentais eram planas, com declividade média inferior a $2 \%$ e, iii) houve limpeza manual prévia dos resíduos culturais, a fim de se evitar o “embuchamento” do subsolador ao operar. O maior CV foi de 13,3\%, observado no LVd-1, mas, na média, os $40 \mathrm{~cm}$ de profundidade planejados foram atingidos para todos os solos.

Em geral, verificou-se a tendência de aumento da largura efetiva de trabalho (LET), com a diminuição do teor de água no solo (Figura 3). A maior coesão entre as partículas do solo em teores de água mais baixos constitui uma explicação plausível para esses resultados. Na média, o LVd-1 apresentou os menores valores de LET, explicado pela menor coesão entre as partículas desse solo, o que prejudicaria a propagação de energia em seus planos de cisalhamento (Nichols \& Reed ${ }^{3}$, 1934 citados por Baver et al., 1972; Nichols et al., 1958). A LET foi um dos parâmetros que apresentou variação dos resultados relativamente alta, com CV de 31,3\% para o LVd-1.

\footnotetext{
${ }^{3}$ NICHOLS, M.L.; REED, I.F. Soil dynamics. VI. Physical reactions of soils to moldboard surfaces.
} Agricultural Engineering, v.15, p.187-190, 1934. 


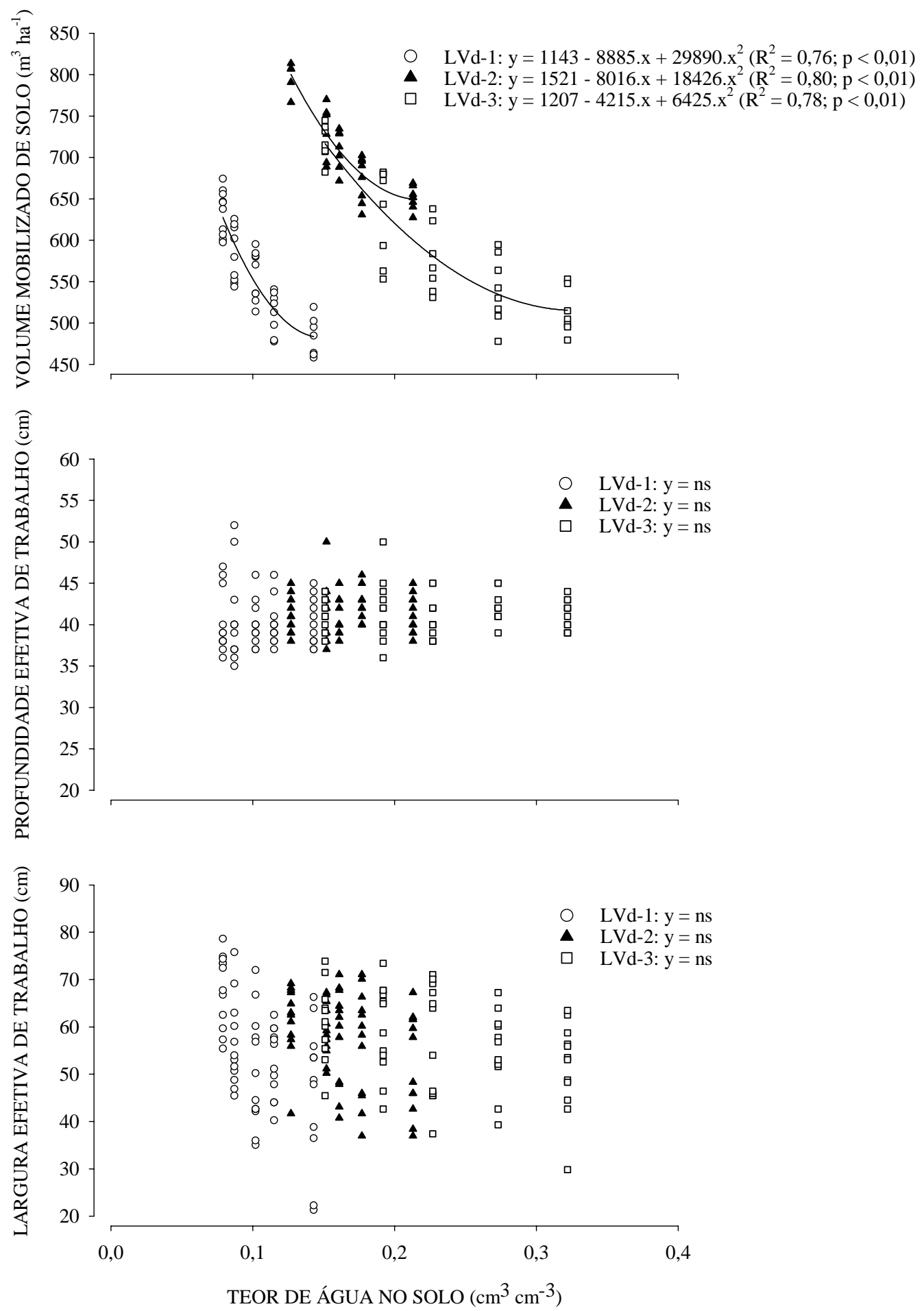

Figura 3 - Volume de solo mobilizado, profundidade efetiva de trabalho e largura efetiva de trabalho em função do teor de água em cada tipo de solo 
A velocidade média de deslocamento (VMD) apresentou tendência de relação inversa com o teor de água no solo (Figura 4). A maior sustentação do solo nessas condições é a causa provável deste efeito, pois, em solos mais secos, o atrito entre o solo e os rodados do trator aumenta (McKyes, 1985; Ohu et al., 1986; Raghavan et al., 1976). Dentre os três Latossolos, o LVd-1 foi aquele que apresentou a menor variação para a VMD (Figura 3). Isso ocorreu porque os solos de textura mais grossa, com distribuição desigual de partículas de diferentes tamanhos, são menos sensíveis à variação de umidade. Por isso, apresentam capacidade de suporte mais estável. Os solos de textura mais fina e com presença de argilas expansíveis são os mais sensíveis à variação de umidade, proporcionando alta capacidade de suporte quando secos e, quando úmidos, baixa capacidade de suporte (Raghavan et al. ${ }^{4}, 1977$, citados por Seixas, 2002). A VMD apresentou variação muito baixa, sendo o CV de 3,6\% o maior, registrado para o LVd-3. Os resultados para a capacidade teórica de trabalho (CTT) são correlatos com os da VMD, uma vez que a CTT é função da VMD, conforme a equação (4) (Figura 4).

O rendimento $(\mathrm{R})$ foi inversamente proporcional ao teor de água no solo (Figura 4). Isso também ocorreu devido a menor capacidade de suporte do solo em teores de água mais elevados, o que diminui o atrito entre o solo e os rodados do trator (McKyes, 1985; Ohu et al., 1986; Raghavan et al., 1976). O LVd-2 e o LVd-3 apresentaram menor rendimento quando úmidos, se comparados com o LVd-1. Isso provavelmente ocorreu por suas texturas e mineralogia, que lhes conferem menor capacidade de suporte em situações de teores de água do solo mais elevados (Raghavan et al, 1977, citados por Seixas, 2002). O maior CV observado foi para o LVd-3, com valor de $11,1 \%$.

\footnotetext{
${ }^{4}$ RAGHAVAN, G.S.; McKYES; V.E.; BEAULIEU, B. Prediction of clay soil compaction. Journal of
} Terra Mechanics, v.14, p.31-38, 1977. 

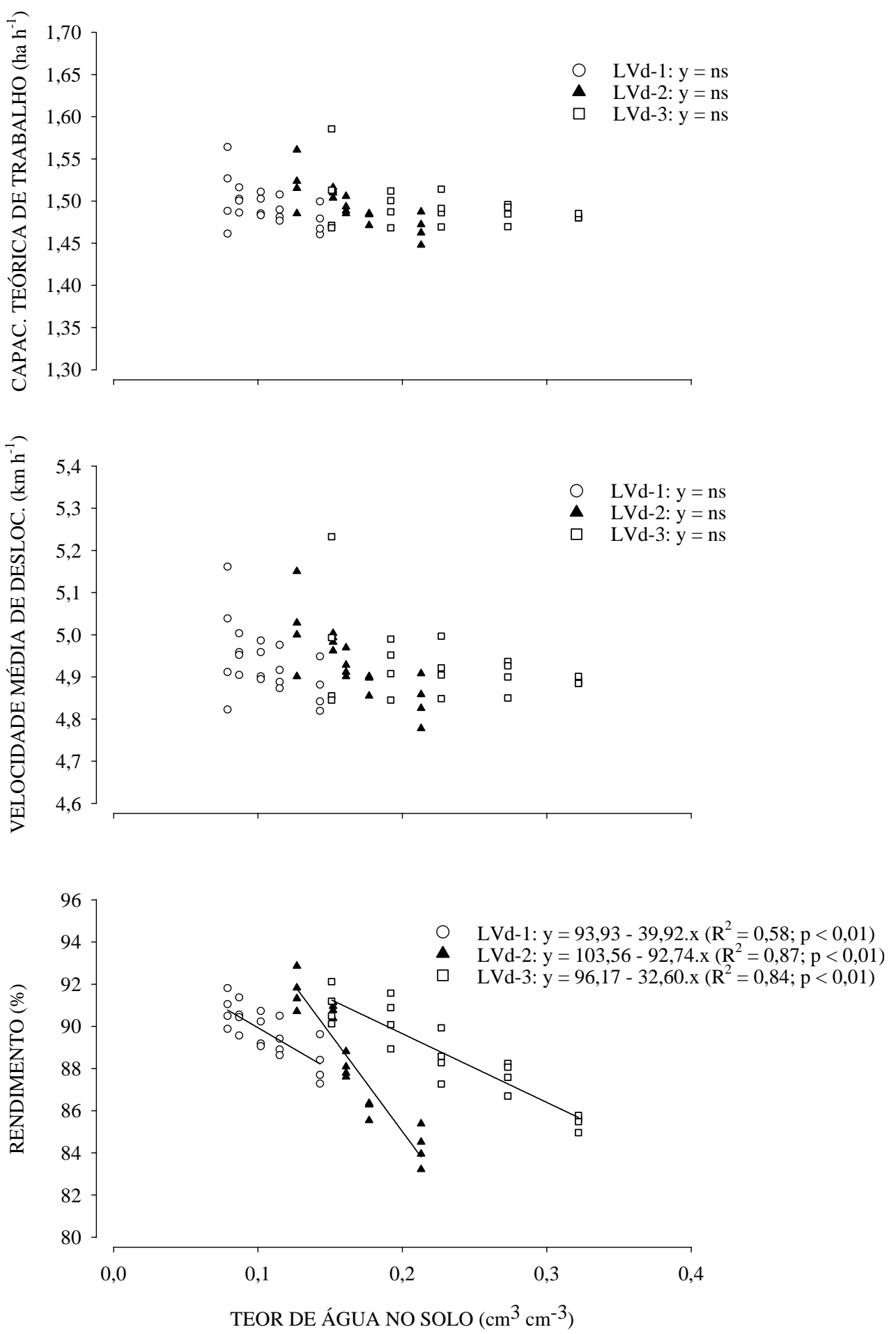

Figura 4 - Capacidade teórica de trabalho, velocidade média de deslocamento e rendimento em função do teor de água em cada tipo de solo 
Dentre os seis parâmetros usados na avaliação do desempenho operacional do subsolador, apenas o volume mobilizado de solo e o rendimento variaram significativamente com o teor de água nos solos. O Latossolo caulinítico e o mais argiloso apresentaram resultados operacionais mais variáveis, principalmente se considerados os parâmetros VMS, LET e R (Figuras 3 e 4). No geral, o desempenho operacional do subsolador foi melhor em teores de água mais baixos, concordando com resultados de outras pesquisas (Beltrame, 1983; Bentivenha et al., 2003; Bicudo, 1991; Gava, 2002; Lanças, 1988; Sasaki et al., 2002; Silveira, 1988; Taylor \& Beltrame, 1980; Yshimine, 1993). Além do ponto de vista operacional, a fisiologia da planta também deve ser considerada, o que implica em realizar a subsolagem em teores intermediários de água no solo, que não prejudiquem a operação e que sejam suficientes para o estabelecimento adequado das plantas.

\subsection{Re-adensamento do sulco de preparo}

A resistência à penetração dos Latossolos, medida nas entrelinhas de subsolagem, foi avaliada em três épocas: logo após a subsolagem, 12 meses e 24 meses pós-subsolagem (Figura 5). Nestas épocas, o teor de água no Latossolo Vermelho Distrófico textura média (LVd-1) variou de 0,076 a $0,091 \mathrm{~cm}^{3} \mathrm{~cm}^{-3}$, no Latossolo Vermelho Distrófico textura argilosa (LVd-2), de 0,139 a 0,152 $\mathrm{cm}^{3} \mathrm{~cm}^{-3}$ e, no Latossolo Vermelho Distrófico textura muito argilosa (LVd-3), de 0,176 a 0,192 $\mathrm{cm}^{3} \mathrm{~cm}^{-3}$ (Figura 5). O LVd-3 apresentou valores médios de resistência à penetração menores que o LVd2 e o LVd-1. Isso pode ser atribuído à estrutura granular do LVd-3, mais desenvolvida e porosa do que a dos demais solos (Tabela 1). Uma vez que a resistência à penetração do solo é fortemente dependente de sua umidade (Baver et al., 1972; Seixas, 2002; Tormena et al., 1998; Voorhees et al., 1978), a maior quantidade de água adsorvida no LVd-3 também contribuiu para a diminuição de sua resistência à penetração, pois esta diminui exponencialmente com o aumento da umidade (Silva et al., 2002a). O LVd-1 foi 
o solo que apresentou resistência à penetração mais alta. Isso é atribuído à sua textura, com distribuição mais ampla dos tamanhos das partículas, o que redunda em maior susceptibilidade à compactação (Diebold ${ }^{5}$, 1954, citado por Seixas, 2002).

Logo após a subsolagem, a área mobilizada de solo (AMS) foi de 0,1766 $\mathrm{m}^{2}$ para o LVd-1, de 0,2221 $\mathrm{m}^{2}$ para o LVd-2 e de 0,1920 $\mathrm{m}^{2}$ para o LVd-3 (Figura 6, Anexos P, S e V). Como a mobilização do solo é função predominante de sua força de coesão e, secundariamente, da adesão e da rugosidade superficial da haste (Lanças, 1988; McKyes, 1985), a maior AMS encontrada no LVd-2 pode estar relacionada à sua estrutura em blocos, que lhe confere maior força de coesão. Além disso, a maior pegajosidade das argilas 1:1, em relação às argilas oxídicas ou textura mais grossa (Gonçalves, 2002a), aumentam a aderência das partículas do LVd-2 ao implemento, resultando em maior área de contato com o solo, conseqüentemente, maior mobilização (Baver et al., 1972; Nichols et al., 1958). A textura bem mais fina do LVd-3, quando comparado ao LVd-1, deve ter sido a causa principal da maior AMS observada nesse solo.

Aos 12 meses pós-subsolagem, a AMS foi de 0,1462 $\mathrm{m}^{2}$ para o LVd-1, de 0,1286 $\mathrm{m}^{2}$ para o LVd-2 e de 0,1213 $\mathrm{m}^{2}$ para o LVd-3 (Figura 6 e Anexos Q, T e W). Isso representou um re-adensamento médio de $17 \%$ para o LVd-1, 42\% para o LVd-2 e 37\% para o LVd-3. Aos 24 meses pós-subsolagem, o re-adensamento médio foi de 31\% para o LVd-1, 56\% para o LVd-2 e 49\% para o LVd-3 (Figura 6 e Anexos R, U e X). Embora a estruturação original do solo seja um processo normalmente demorado, agregados desestruturados por implementos de preparo de solo geralmente se rearranjam parcial ou totalmente durante um período de tempo mais curto (Horn \& Dexter, 1989). O efeito de rearranjo parcial é conhecido geralmente por endurecimento (“age hardening”) ou re-adensamento (“strenght regain”). O rearranjo total é conhecido por tixotropia (Horn \& Dexter, 1989; Utomo \& Dexter, 1981). A desestruturação e a estruturação do

\footnotetext{
${ }^{5}$ DIEBOLD, C.H. Permeability and intake rates of medium textured soils in relation to silt content and degree of compaction. Soil Science Society of America Journal, v.18, p.339-343, 1954.
} 
solo e o re-adensamento do perfil mobilizado por implementos de preparo são processos que ocorrem naturalmente em campo, sendo comandados por diferentes fatores. A AMS nos pontos E15 e D15 apresentou maior variação (Figura 6), fato que pode estar relacionado com o modo de ruptura do solo em forma de cone, proporcionado pela haste subsoladora (Nichols \& Reed, 1934, citados por Baver et al., 1972; Nichols et al., 1958).

Em condições controladas, Chaney \& Swift (1986), Horn \& Dexter (1989), Richardson (1976) e Utomo \& Dexter (1982), verificaram que os ciclos de umedecimento e secagem têm papel primário na restruturação do solo. Contudo, há diferenças na atuação desses ciclos, quando considerados o solo estruturado e o perfil de solo mobilizado por implemento de preparo. No solo estruturado, eles podem provocar tanto a desestruturação como a estruturação do solo. A desestruturação ocorre na secagem muito intensa e no umedecimento muito rápido ou por períodos muito longos. A secagem gradual e o umedecimento lento e constante favorecem a estruturação.

No solo desestruturado por implementos de preparo, os ciclos de umedecimento e secagem geralmente provocam o re-adensamento, por meio de atração entre as partículas de solo durante a secagem, da lixiviação de substâncias cimentantes e do encrostamento (Baver et al., 1972; Chaney \& Swift, 1986; Horn \& Dexter, 1989; Richardson, 1976; Utomo \& Dexter, 1981; Utomo \& Dexter, 1982).

O maior re-adensamento observado no LVd-2 está relacionado à sua maior riqueza em caulinita, que proporcionaria maior capacidade de contração e expansão (Baver et al., 1972; Gonçalves, 2002a; Gonçalves, 2002b) e, conseqüentemente, maior rearranjo dos agregados presentes no sulco de preparo (Ferreira, 1988; Oliveira, 1992; Oliveira, 1994). O LVd-3 apresentou re-adensamento tão elevado quanto o do LVd-2. Isto está relacionado aos altos teores de argila e matéria orgânica deste solo, o que implica em taxas mais elevadas de cimentação, expansão e contração dos agregados (Soulides \& Allinson, 1961). O LVd-1 foi o solo que apresentou o menor readensamento (Figura 6), efeito atribuído à sua textura mais grosseira e ao seu menor teor 
de matéria orgânica (Tabela 1). De modo geral, o re-adensamento ocorreu no sentido do exterior (locais E15 e D15) para o centro do sulco (local C) (Figura 6). Isto pode estar relacionado à maior proximidade das laterais do sulco de preparo com o solo estruturado, que expande e contraí mais do que o solo desestruturado dentro do sulco. Outro fator que pode ter provocado o re-adensamento neste sentido foi a lixiviação de substâncias cimentantes pelas paredes do sulco, localizadas entre os pontos E30 e D30 (Figura 6).

A AMS apresentou relação inversa com o tempo pós-subsolagem para os três Latossolos, durante os 24 meses de avaliação (Figura 7). Durante esse período, observou-se que cerca da metade da AMS foi perdida, principalmente se considerados os solos mais argilosos. Os resultados concordam com as observações de alguns pesquisadores (Cassel, 1979; Hénin, 1976; Silva et al., 1990), apesar da grande variabilidade das informações existentes quanto à duração dos efeitos da subsolagem, como mostraram os estudos de Taylor \& Beltrame (1980), que observaram o efeito da subsolagem perdurar por até quatro anos nos solos argilosos. Essas pesquisas mostram que a duração dos efeitos da subsolagem deve estar relacionada às condições físicas, morfológicas e mineralógicas dos solos.

\subsection{Teor de água ideal para a subsolagem}

A resistência à penetração do solo, avaliada antes da subsolagem, variou entre os Latossolos e seus teores de água (Figura 8). O Latossolo Vermelho Distrófico textura muito argilosa (LVd-3) apresentou valores médios de resistência à penetração menores que o Latossolo Vermelho Distrófico textura argilosa (LVd-2) e o Latossolo Vermelho Distrófico textura média (LVd-1). Isso pode ser atribuído aos maiores teores de argila e matéria orgânica do LVd-3 (Tabela 1), que aumentam a capacidade de adsorção de água 
ÍNDICE DE CONE (MPa)
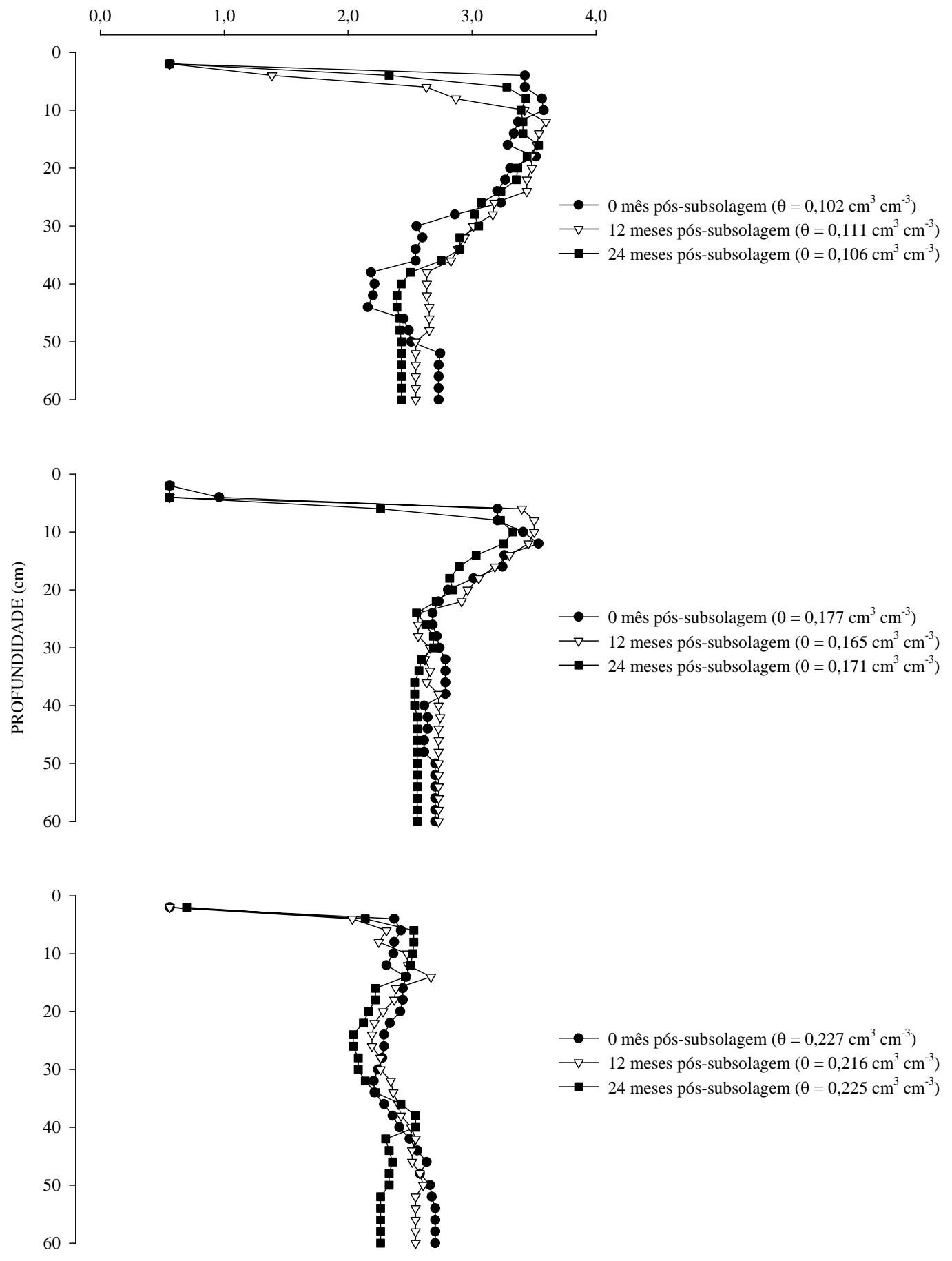

Figura 5 - Resistência à penetração do solo, avaliada aos 0, 12 e 24 meses pós-subsolagem: a) Latossolo Vermelho Distrófico textura média, b) Latossolo Vermelho Distrófico textura argilosa e c) Latossolo Vermelho Distrófico textura muito argilosa 
LOCAL (cm)
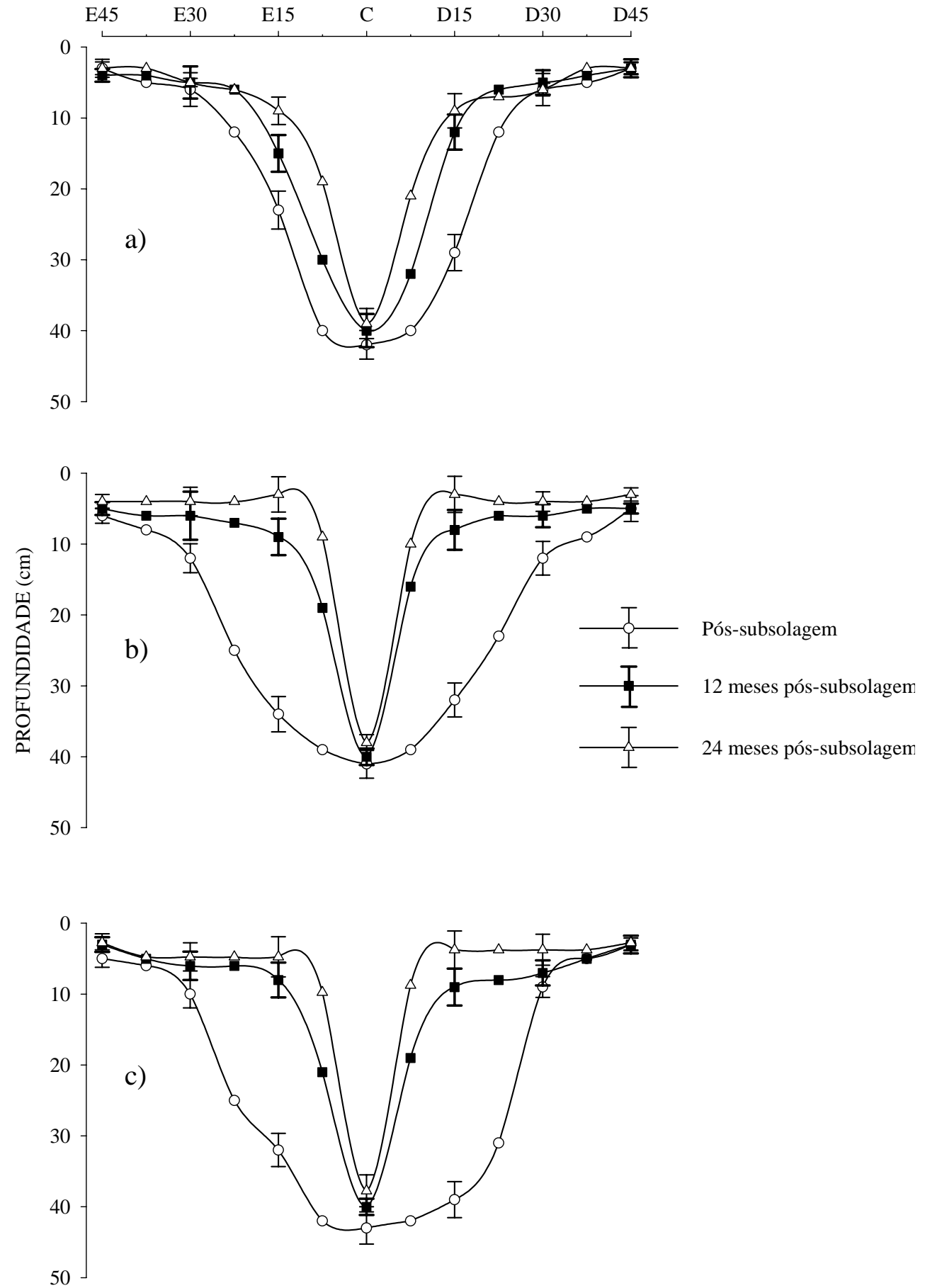

Figura 6 - Área mobilizada de solo em função do tempo pós-subsolagem e respectivos desvios padrões: a) Latossolo Vermelho Distrófico textura média, b) Latossolo Vermelho Distrófico textura argilosa e c) Latossolo Vermelho Distrófico textura muito argilosa 


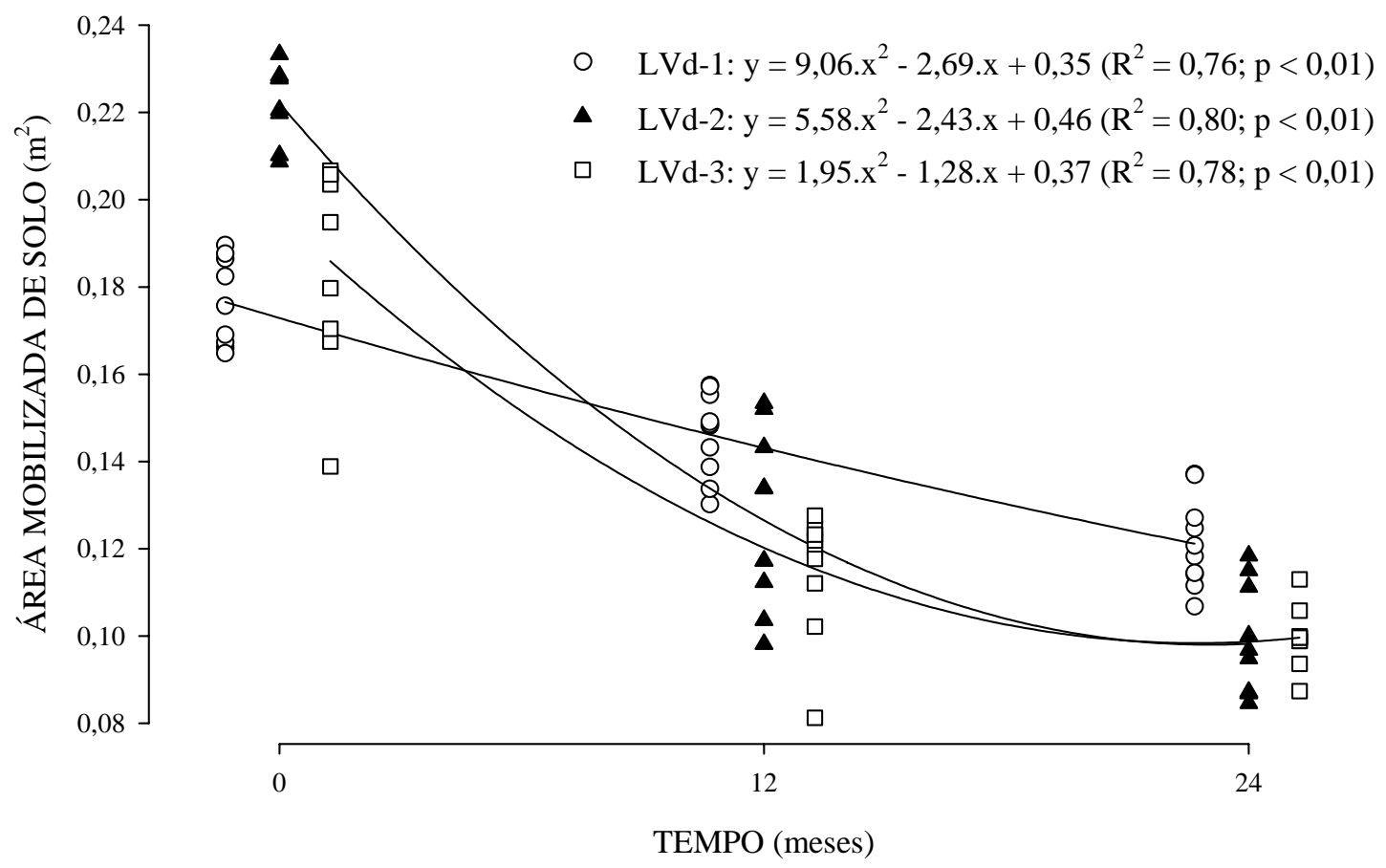

Figura 7 - Área mobilizada de solo em função do tempo pós-subsolagem

pelo solo (Baver et al., 1972; Seixas, 2002). Uma vez que a resistência à penetração do solo é fortemente dependente de sua umidade (Baver et al., 1972; Seixas, 2002; Tormena et al., 1998; Voorhees et al., 1978), a maior quantidade de água adsorvida no LVd-3 implica em valores menores de resistência à penetração, pois esta diminui exponencialmente com o aumento da umidade (Silva et al., 2002a). O LVd-2 apresentou valores de resistência à penetração mais próximos do LVd-1, apesar desse solo possuir teores de argila e silte bem elevados. Isso é atribuído à mineralogia mais rica em caulinita desse solo (Tabela 1), o que redunda em maior dureza, coesão e resistência mecânica em teores de água mais baixos (Baver et al., 1972; Gonçalves, 2002a).

Nos três Latossolos, a camada de $0 \mathrm{a} 10 \mathrm{~cm}$ apresentou valores de resistência à penetração menores do que a camada de 10 a 30 cm (Figura 9). A causa mais provável 
disso foi o maior grau de desenvolvimento da estrutura na camada superficial, responsável pela menor densidade e a maior friabilidade do solo (Baver et al., 1972). Valores mais altos de resistência à penetração na camada de 10 a $30 \mathrm{~cm}$ dos três Latossolos podem ter sido originados pela pressão exercida por rodados na superfície do solo, que se propaga em profundidade por meio de ondas (Chancellor et al., 1962; Gill \& Reaves, 1956; Raghavan et al., 1976), pois as áreas haviam sido colhidas pouco antes da instalação do experimento.

A área mobilizada de solo (AMS) e o teor de água apresentaram relação quadrática e inversa para os três Latossolos (Figura 10). Verificou-se que quanto menor era o teor de água no solo, maior era a AMS. Segundo McKyes (1985) e Lanças (1988), a mobilização do solo é função predominante de sua força de coesão e, secundariamente, da adesão e da rugosidade superficial da haste. As forças de coesão entre as partículas do solo aumentam à medida que o solo seca (Baver et al., 1972; Silva et al., 2002a). Além disso, o solo mais coeso proporciona propagação mais eficiente nos planos de cisalhamento do solo (à frente, acima e lateralmente à haste subsoladora), aumentando a pressão exercida pelo implemento (Nichols \& Reed, 1934, citados por Baver et al, 1972; Nichols et al., 1958). Outro fator que afeta a mobilização dos solos em teores de água mais baixos é o efeito lubrificante da água, que é reduzido nessa situação (Rosa Júnior, 2000; Silva et al., 2002a), potencializando o atrito entre o solo e o implemento.

O teor de água também afetou o formato das secções mobilizadas de solo (Figura 11, Anexos A, B, C, D, E, F, G, H, I, J, K, L, M, N e O). O cisalhamento lateral do solo, desde a ponteira até sua superfície, segue um plano inclinado em relação à horizontal de aproximadamente $45^{\circ}$, principalmente quando o solo apresenta baixo teor de água (Fernandes et al., 1981; Nichols et al., 1958; Rípoli et al., 1985). O LVd-1 e o LVd-3, com teores de água mais baixos, apresentaram essa característica, mas, em teores mais elevados, o ângulo de cisalhamento lateral desses solos foi menor que $45^{\circ}$ (Figuras 11a e 11c). Esse efeito é atribuído ao poder lubrificante da água, que não potencializa o atrito entre a haste subsoladora e o solo, quando este está muito úmido. O ângulo de 


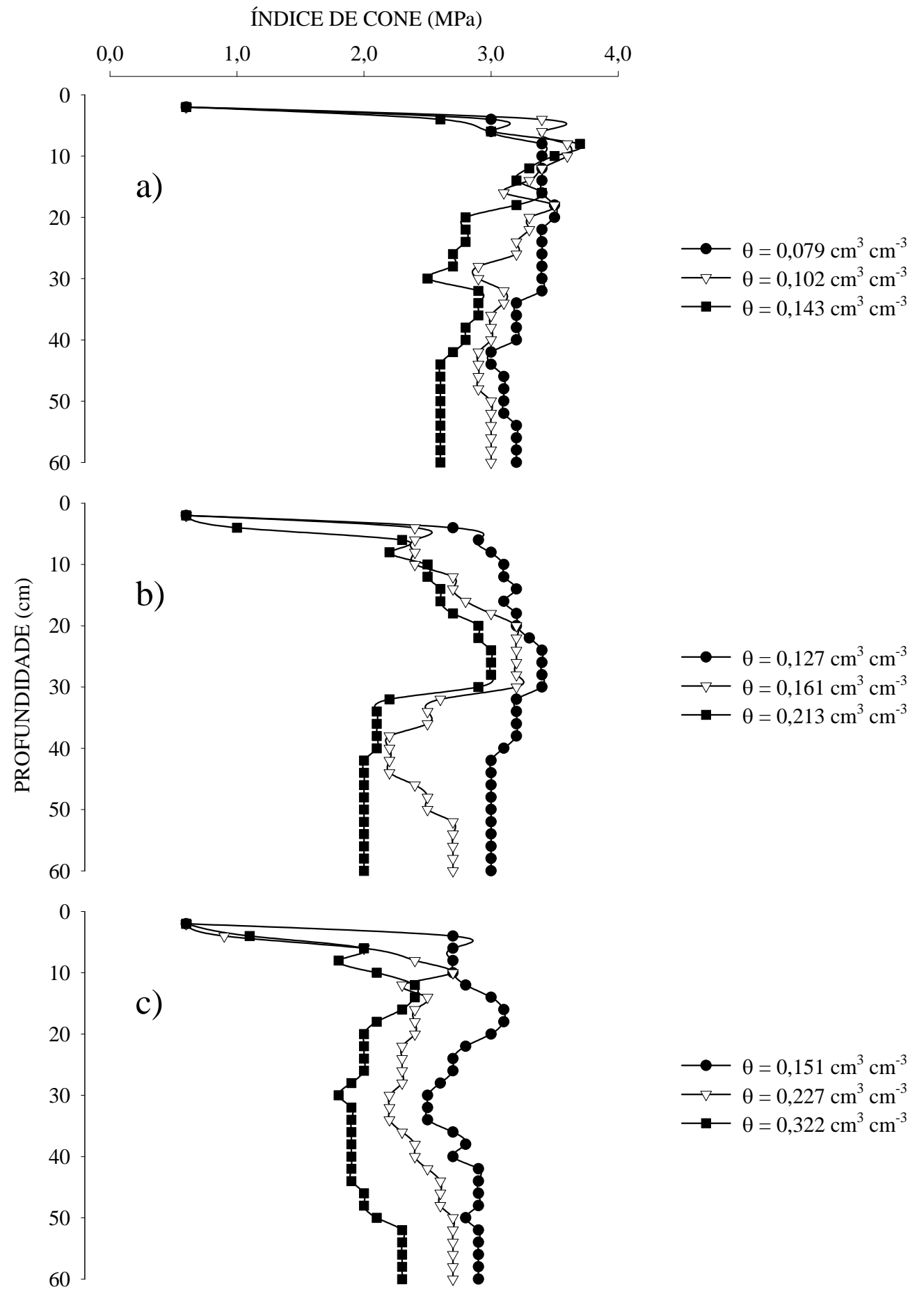

Figura 8 - Resistência à penetração do solo, avaliada antes da subsolagem, com diferentes teores de água: a) Latossolo Vermelho Distrófico textura média, b) Latossolo Vermelho Distrófico textura argilosa e c) Latossolo Vermelho Distrófico textura muito argilosa 


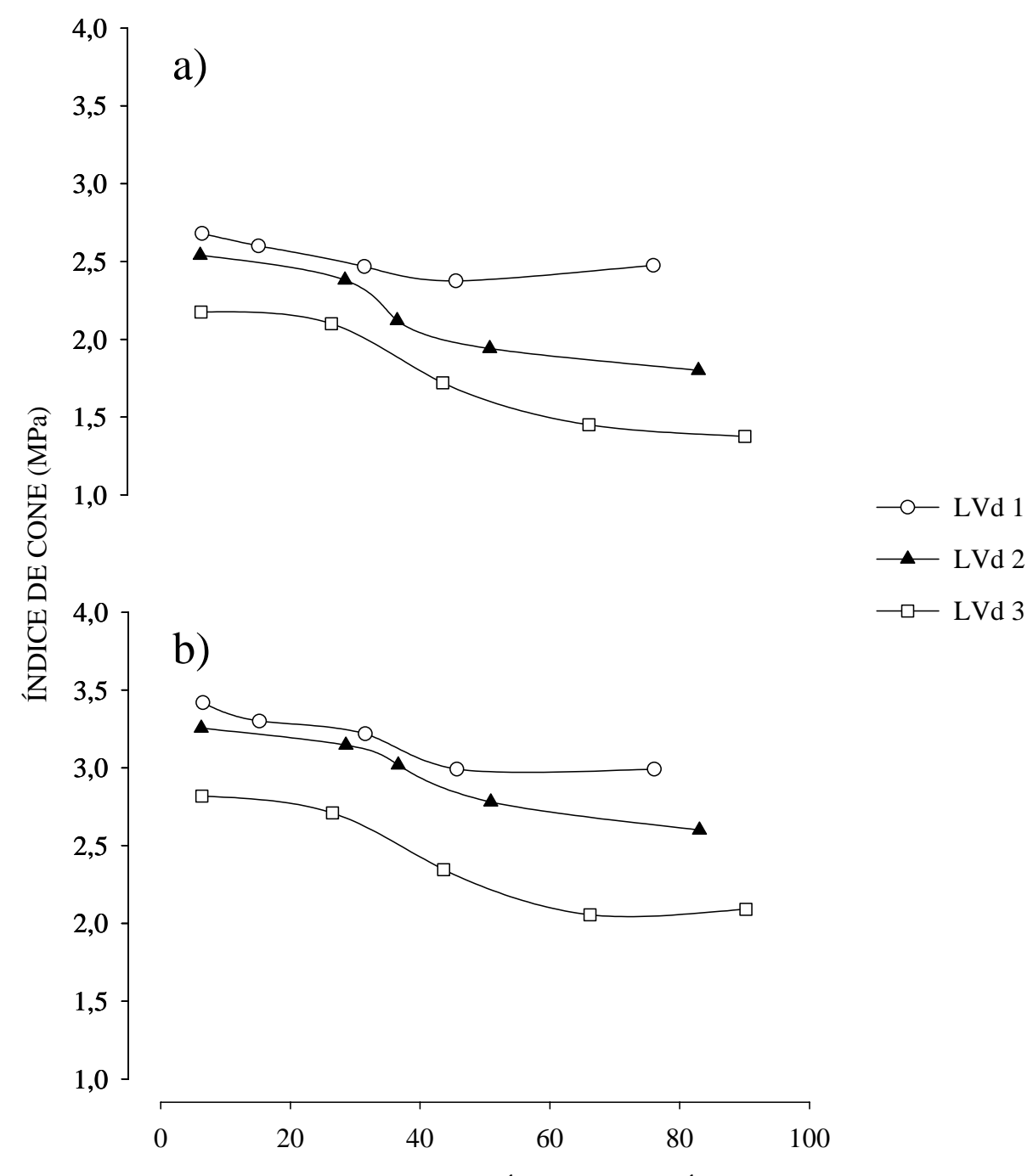

PORCENTAGEM RELATIVA DE ÁGUA DISPONÍVEL NO SOLO

Figura 9 - Variação da resistência à penetração em função da porcentagem relativa de água disponível nos três Latossolos: a) camada 0 a $10 \mathrm{~cm}$; b) camada 10 a $30 \mathrm{~cm}$

cisalhamento lateral do $\mathrm{LVd}-2$ foi maior que $45^{\circ}$, mesmo em teores de água mais elevados (Figura 11B). A estrutura em blocos, devido à maior riqueza em caulinita deste solo, conseqüentemente maior coesão, é a causa mais provável deste efeito. 
Entre os solos mais friáveis, o LVd-3, de textura fina e estrutura moderada granular, apresentou maior mobilização que o LVd-1, de textura mais grossa e estrutura fraca granular (Tabela 1, Figuras 10 e 11). Segundo Baver et al. (1972) e Gonçalves (2002a), os solos de textura fina são mais coesos quando secos. Yshimine (1993) também observou maior AMS num Latossolo Vermelho argiloso, comparativamente a um Latossolo Vermelho de textura média.

O LVd-1 apresentou o maior valor de densidade máxima, seguido pelo LVd-2 e LVd-3 (Figura 7). Isso ocorreu devido aos maiores teores de argila e matéria orgânica do LVd-3 (Tabela 1), que aumentam o poder de adsorção de água pelo solo (Dias Júnior \& Estanislau, 1999; Ekuwe \& Stone, 1997; Howard et al., 1981; Ohu et al., 1986; Silva et al., 1986). Em função da baixa compacidade da água, os solos com teores de argila e matéria orgânica mais elevados, que adsorvem mais água, geralmente apresentam menores índices de compactação (Baver et al., 1972; Figueiredo et al., 2000; Tormena et al., 1998; Voorhees et al., 1978). Apesar do LVd-2 possuir teores intermediários de argila e matéria orgânica, este solo apresentou um valor de densidade máxima estatisticamente igual ao do LVd-3. Isso se deve à sua mineralogia caulinítica, que aumenta sua capacidade de retenção de água e expansão, quando comparada com a dos solos ricos em óxidos de ferro e alumínio, LVd-3, e a do solo de textura média, LVd-1 (Baver et al., 1972).

Os teores de água dos três Latossolos, necessários para atingir suas densidades máximas, também variaram (Figura 12). Enquanto o LVd-1 apresentou densidade máxima de $1,93 \mathrm{~g} \mathrm{~cm}^{-3}$ no teor de água de $0,15 \mathrm{~cm}^{3} \mathrm{~cm}^{-3}$, o LVd-2 e o LVd-3 apresentaram densidades máximas de 1,88 e 1,87 nos teores de água de 0,20 e 0,32, respectivamente. Este efeito está diretamente relacionado à composição textural e mineralógica dos solos. Os teores de argila e matéria orgânica influenciam a posição da curva de compactação ao longo do eixo do teor de água, enquanto que o teor de areia influi na amplitude da curva de compactação (Ekuwe \& Stone, 1997; Howard et al., 1981; Ohu et al., 1986; Silva et al., 1986). 

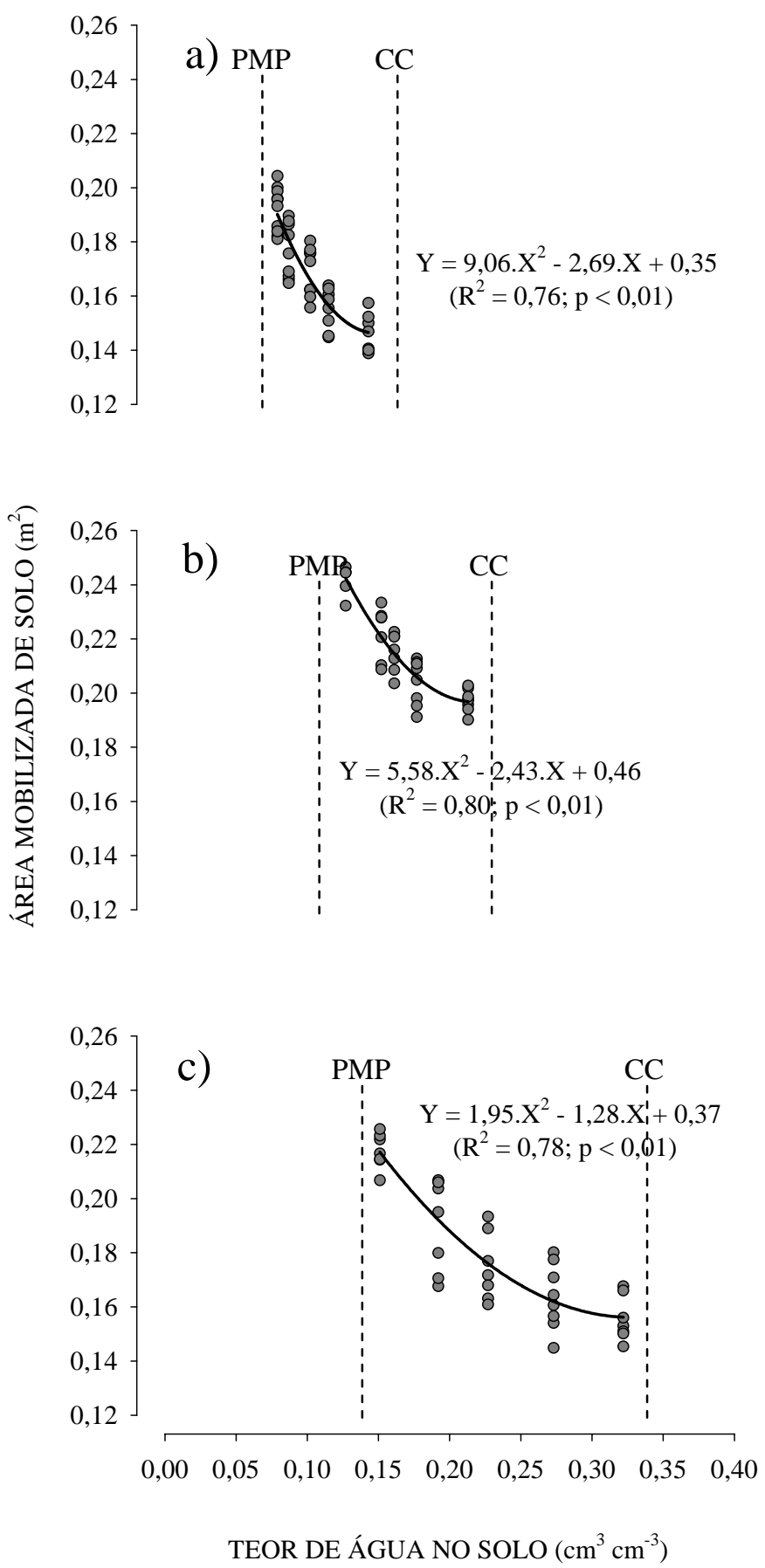

Figura 10 - Área mobilizada de solo em função do teor de água: a) Latossolo Vermelho Distrófico textura média, b) Latossolo Vermelho Distrófico textura argilosa e c) Latossolo Vermelho Distrófico textura muito argilosa. PMP significa Ponto de Murcha Permanente (-1,5 MPa) e, CC, Capacidade de Campo (-0,01 MPa) 


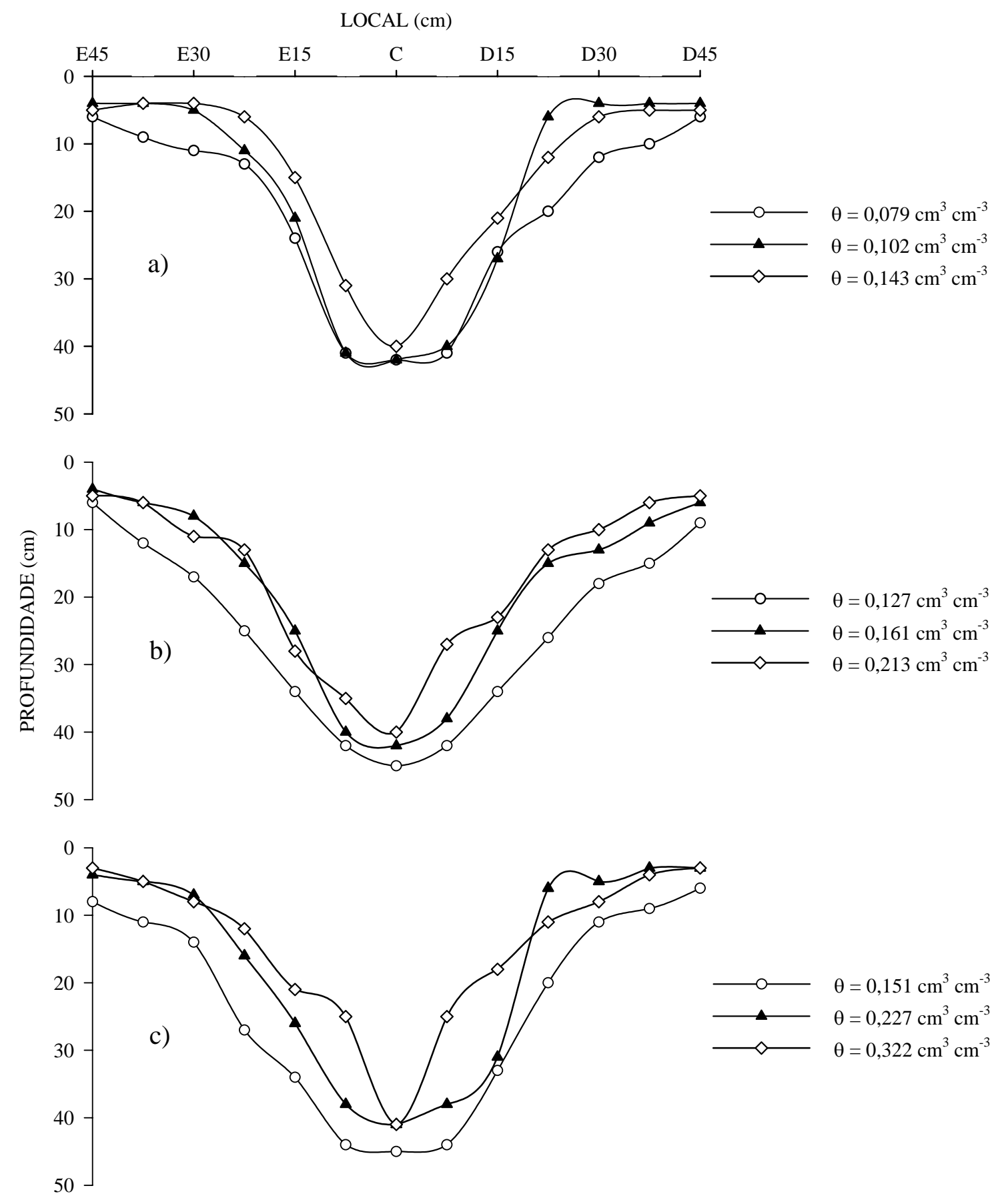

Figura 11 - Área mobilizada de solo em função do teor de água: a) Latossolo Vermelho Distrófico textura média, b) Latossolo Vermelho Distrófico textura argilosa e c) Latossolo Vermelho Distrófico textura muito argilosa 
Uma vez que o ensaio de Proctor não é uma análise de rotina em laboratórios de física do solo, alguns pesquisadores têm buscado métodos alternativos para determinar a umidade em que ocorre a máxima densidade do solo. Assim, usam-se alguns atributos como 90\% do limite de plasticidade, 90\% da água retida a -0,01 MPa ou a água retida a -0,033 MPa (Figueiredo et al., 2000). De fato, os valores de 90\% da capacidade de campo dos três Latossolos (0,15 para o LVd-1, 0,21 para o LVd-2 e 0,31 $\mathrm{cm}^{3} \mathrm{~cm}^{-3}$ para o LVd-3), aproximaram-se bastante dos teores de água necessários para se obter a densidade máxima desses solos (0,15 para o LVd-1, 0,20 para o LVd-2 e 0,32 $\mathrm{cm}^{3} \mathrm{~cm}^{-3}$ para o LVd-3).

Com base nos resultados de mobilização do solo e do ensaio de Proctor normal, procurou-se obter um intervalo hídrico que apresentasse valores mais altos de AMS e níveis de compactação do solo aceitáveis, denominado intervalo hídrico de subsolagem (Figura 13). Considerando que Campbell et al. (1980), Figueiredo et al. (2000), Howard et al. (1981), McKyes (1985) e Ojeniyi \& Dexter (1979), recomendaram a mecanização do solo abaixo dos teores de água críticos (90\% do limite de plasticidade, 90\% da água retida a $-0,01 \mathrm{MPa}$ ou a água retida a $-0,033 \mathrm{MPa}$ ), optou-se por $80 \%$ da capacidade de campo e o ponto de murcha permanente como limites hídricos superior e inferior, respectivamente. Verificou-se que o LVd-1 deveria ser subsolado entre os teores de água de 0,07 a $0,13 \mathrm{~cm}^{3} \mathrm{~cm}^{-3}$, o LVd-2 entre os teores de água de 0,12 a $0,19 \mathrm{~cm}^{3} \mathrm{~cm}^{-3}$ e o LVd-3 entre os teores de água de 0,14 a $0,27 \mathrm{~cm}^{3} \mathrm{~cm}^{-3}$. Esses resultados mostram que a subsolagem é mais eficiente se realizada em teores de água mais baixos, como afirmam alguns pesquisadores (Beltrame, 1983; Bentivenha et al., 2003; Bicudo, 1990; Gava, 2002; Gonçalves, 2002b; Lanças, 1988; McKyes, 1985; Rípoli et al., 1985; Sasaki et al., 2002; Yshimine, 1993).

O LVd-2 apresentou maiores restrições hídricas à subsolagem, se comparado com o LVd-1 e o LVd-2 (Figura 13). Isso pode ter ocorrido em função de sua maior riqueza em caulinita, que resulta em maior aderência e plasticidade em teores de água elevados (Baver et al., 1972; Gonçalves, 2002a), prejudicando o desempenho do 
subsolador. O LVd-1 e o LVd-3 mostraram menor restrição hídrica à subsolagem, provavelmente em função de sua maior permeabilidade, grau de estruturação, aderência e friabilidade (Baver et al., 1972; Gonçalves, 2002a). 

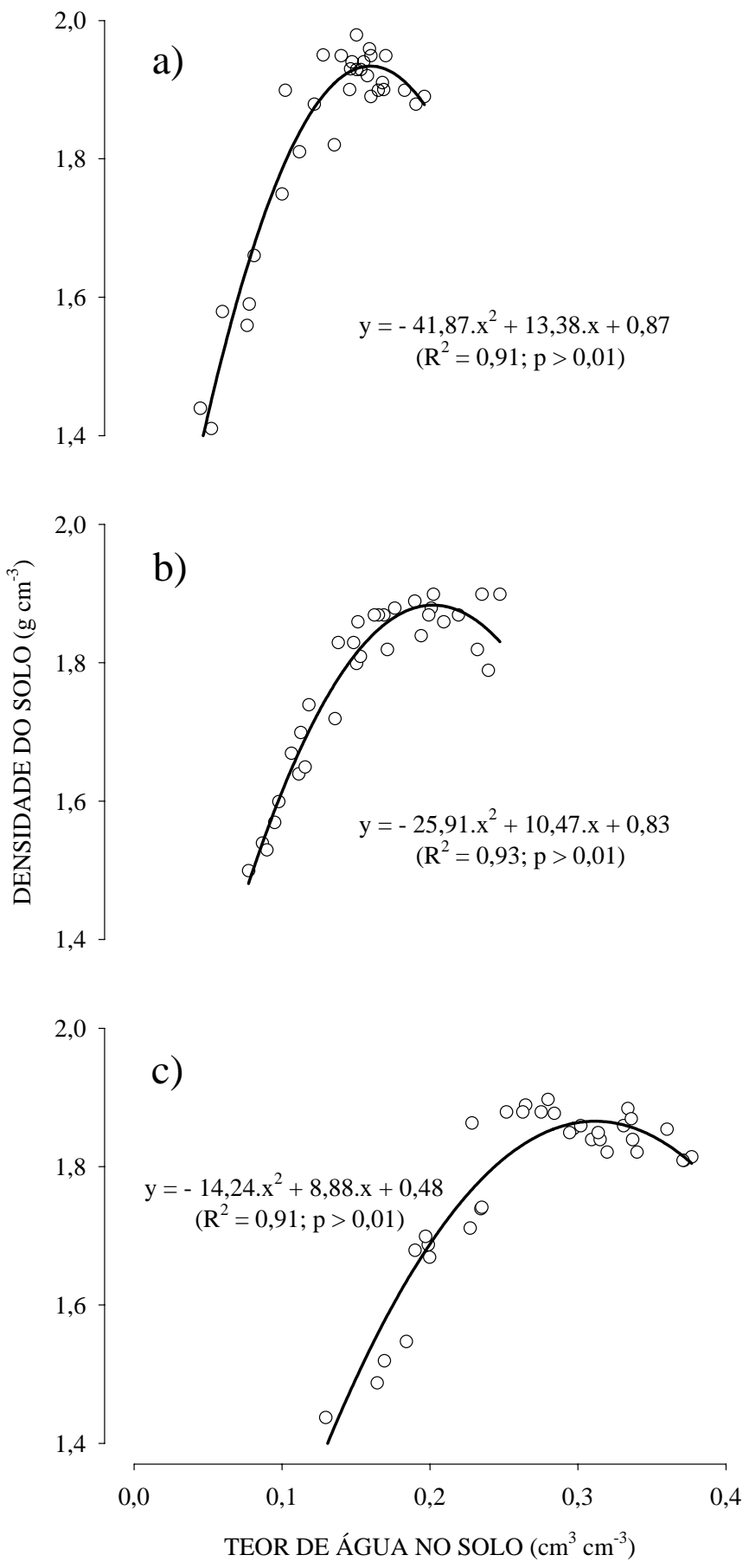

Figura 12 - Curvas de compactação obtidas pelo ensaio de Proctor normal: a) Latossolo Vermelho Distrófico textura média, b) Latossolo Vermelho Distrófico textura argilosa e c) Latossolo Vermelho Distrófico textura muito argilosa 

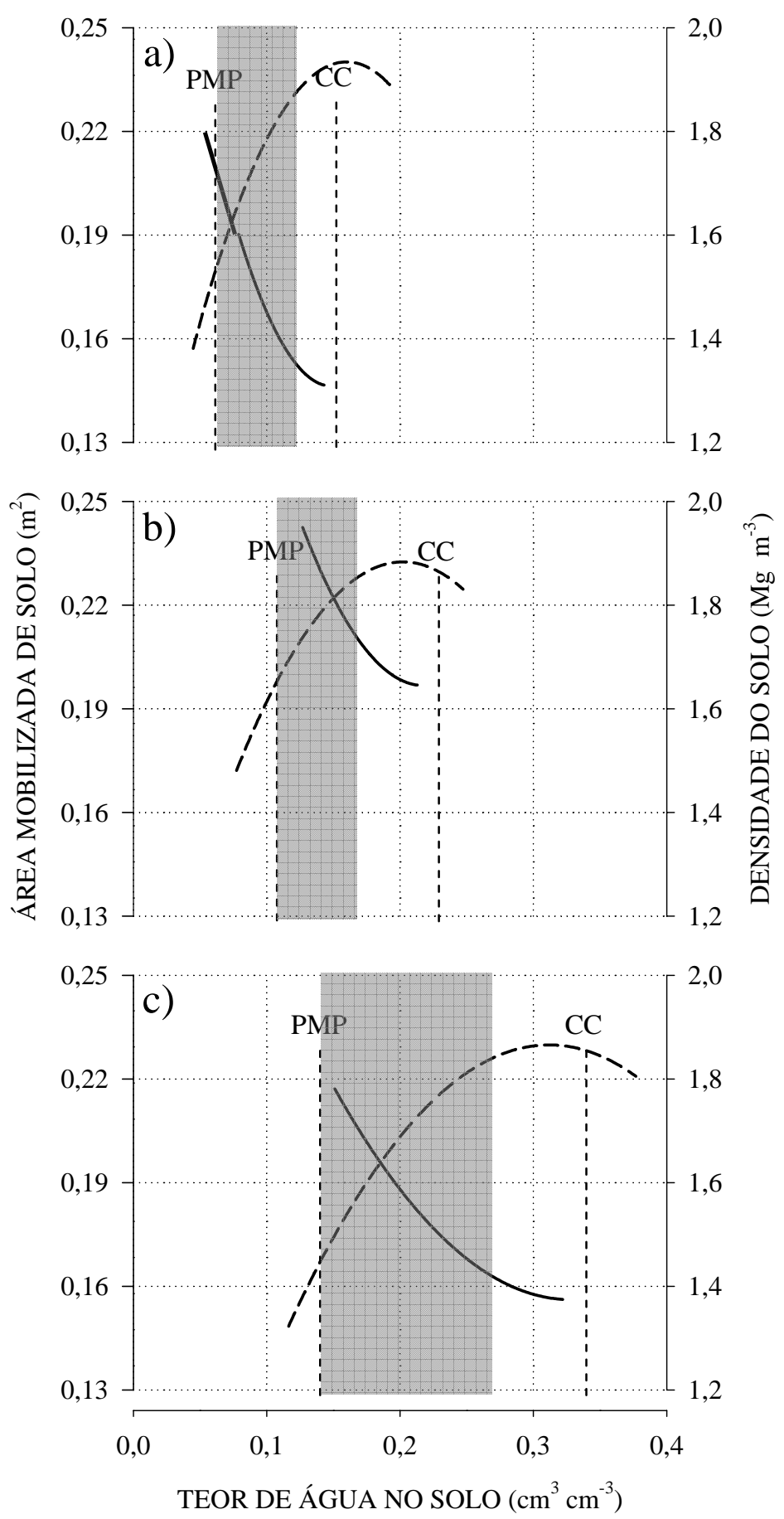

Figura 13 - Intervalo hídrico de subsolagem em função da densidade ( - - ), da área mobilizada ( - ) e do teor de água nos solos: a) Latossolo Vermelho Distrófico textura média, b) Latossolo Vermelho Distrófico textura argilosa e c) Latossolo Vermelho Distrófico textura muito argilosa. PMP significa Ponto de Murcha Permanente (-1,5 MPa) e, CC, Capacidade de Campo (-0,01 MPa). A área hachurada representa o intervalo hídrico em que a subsolagem deve ser realizada 


\section{CONCLUSÕES}

- Nos três Latossolos estudados, o desempenho operacional do subsolador foi melhor em teores mais baixos de água;

- No geral, quando os teores de água estiveram entre 50 e 60\% da capacidade de campo, os resultados operacionais foram melhores e a qualidade técnica do preparo de solo mais adequada;

- A maior mobilização dos solos foi observada naqueles com mineralogia caulinítica e com textura muito argilosa (mineralogia oxídica). Nesses solos, praticamente a metade da área mobilizada inicial foi modificada aos 24 meses pós-subsolagem (56\% de readensamento para o LVd-2 e 49\% para o LVd-3);

- Os três solos apresentaram relação parabólica e inversa entre a área mobilizada de solo e o aumento de seu teor de água;

- O Latossolo caulinítico apresentou intervalo hídrico de subsolagem mais restrito do que os Latossolos oxídicos;

- O intervalo hídrico de subsolagem foi baseado em dois parâmetros que podem apresentar muita variação. Essas limitações fazem com que novos estudos sejam realizados, a fim de se adotar ou não esse intervalo como um índice a ser considerado no preparo do solo. 


\section{REFERÊNCIAS BIBLIOGRÁFICAS}

AMERICAN SOCIETY OF AGRICULTURAL ENGINEERS. ASAE Standards Terminology and definitions for soil tillage and soil-tool relationships - ASAE EP291.1. 40.ed. St. Joseph, 1982. p.229-241.

BALAStreirE, L. A. Máquinas Agrícolas. São Paulo: Ed. Manole, 1987. 310 p.

BAVER, L.D.; GARDNER, W.H.; GARDNER, W.R. Soil Physics. Nova York: John Wiley, 1972. 498 p.

BELTRAME, L.F.S. Avaliação do desempenho de três subsoladores em Latossolo Vermelho Escuro. Engenharia Agrícola, v.7, n.1, p.37-52, 1983.

BENTIVENHA, S.R.P.; GONÇALVES, J.L.M.; SASAKI, C.M. Mobilização do solo e crescimento inicial do eucalipto em função do tipo de haste subsoladora, profundidade de trabalho e características do solo. Engenharia Agrícola, v.23, n.3, p.588-605, 2003.

BICUDO, S.J. Subsolador: algumas relações entre profundidade de trabalho, largura das sapatas e número de hastes. Botucatu, 1990. 130 p. Tese (Doutorado) - Universidade Estadual Paulista “Júlio de Mesquita Filho”. 
BLAKE, G.R.; HARTGE, K.H. Bulk density. In: KLUTE, A. Methods of soil analysis: physical and mineralogical methods. Madison: American Society of Agronomy, 1986. p.363-375.

CAMPBELL, D.J.; STAFFORD, J.V.; BLACKWELL, P.S. The plastic limit, as determined by the drop-cone test, in relation to the mechanical behavior of soil. Journal of Soil Science, v.31, p.11-24, 1980.

CASSEL, D.K. Subsoiling. Crops and Soils Magazine, v.32, p.7-10, 1979.

CHANCELLOR, W.J.; SCHMIDT, R.H.; SOEHNE, W.H. Laboratory measurements of soil compaction and plastic flow. Transactions of the ASAE, v.5, n.2, p.235-239, 1962.

CHANEY, K.; SWIFT, R.S. Studies on aggregate stability. I: Re-formation of soil aggregates. Journal of Soil Science, v.37, p.329-335, 1986.

DIAS JÚNIOR, M.S.; ESTANISLAU, W.T. Grau de compactação e retenção de água de Latossolos submetidos a diferentes sistemas de manejo. Revista Brasileira de Ciência do Solo, v.23, p.45-51, 1999.

EKWUE, E.I.; STONE, R.J. Density-moisture relations of some Trinidadian soils incorporated with sewage sludge. Transactions of the ASAE, v.40, n.2, p.317-323, 1997.

EMPRESA BRASILEIRA DE PESQUISA AGROPECUÁRIA - EMBRAPA. Manual de métodos de análise de solos. 2.ed. Rio de Janeiro, 1997. 212 p.

EMPRESA BRASILEIRA DE PESQUISA AGROPECUÁRIA - EMBRAPA. Sistema brasileiro de classificação de solos. Brasília, 1999a. 412 p. 
EMPRESA BRASILEIRA DE PESQUISA AGROPECUÁRIA - EMBRAPA. Manual de análises químicas de solos, plantas e fertilizantes. Brasília, 1999b. 370 p.

FERNANDES, J.; FURLANI NETO, V.L.; STOLF, R. Dimensionamento do subsolador alado. Brasil Açucareiro, v.97, n.2, p.32-38, 1981.

FERREIRA, M.M. Influência da mineralogia da fração argila nas propriedades físicas de Latossolos brasileiros. Viçosa, 1988. 79 p. Tese (Doutorado) - Universidade Federal de Viçosa.

FIGUEIREDO, L.H.A.; DIAS JUNIOR, M.S.; FERREIRA, M.M. Umidade crítica de compactação e densidade do solo máxima em resposta a sistemas de manejo num latossolo roxo. Revista Brasileira de Ciência do Solo, v.24, p.487-493, 2000.

GADANHA JÚNIOR, C.D.; MOLIN, J.P.; COELHO, J.L.D.; YAHN, C.H.; TOMIMORI, S.M.A. Máquinas e implementos agrícolas do Brasil. São Paulo: CT/CNPq/IBOCT/IPT/CIENTEC/NSI-MA, 1991. 468 p.

GAMERO, C.A.; LANÇAS, K.P. Ensaio \& certificação das máquinas de mobilização periódica do solo. In: MIALHE, L.G. Máquinas agrícolas: ensaio \& certificação. Piracicaba: FEALQ, 1996. p.463-514.

GARNER, T.H.; REYNOLDS, W.R.; MUSEN, H.L.; MILES, G.E.; DAVIS, J.W.; WOLF, D.; PEIPER, U.M. Energy requirement for subsoiling Coastal Plain Soils. Transactions of the ASAE, v.30, n.2, p.343-349, 1987.

GAVA, J.L. Cultivo mínimo de solos com textura arenosa em áreas planas e suaveonduladas. In: GONÇALVES, J.L. M.; STAPE, J.L. Conservação e cultivo de solos para plantações florestais. Piracicaba: IPEF, 2002. cap.5, p.221-244. 
GILL, W.R.; REAVES, C.A. Compaction patterns of smooth rubber tires. Agricultural Engineering, v.37, p.677-680, 1956.

GONÇALVES, J.L.M. Principais solos usados para plantações florestais. In: GONÇALVES, J.L.M.; STAPE, J.L. Conservação e cultivo de solos para plantações florestais. Piracicaba: IPEF, 2002a. cap.1, p.1-45.

GONÇALVES, J.L.M. Conservação do solo. In: GONÇALVES, J.L.M.; STAPE, J.L. Conservação e cultivo de solos para plantações florestais. Piracicaba: IPEF, 2002b. cap.2, p.47-129.

GONÇALVES, J.L.M.; STAPE, J.L.; WICHERT, M.C.P.; GAVA, J.L. Manejo de resíduos vegetais e preparo de solo. In: GONÇALVES, J.L.M.; STAPE, J.L. Conservação e cultivo de solos para plantações florestais. Piracicaba: IPEF, 2002. cap.3, p.131-204.

GONÇALVES, J.L.M.; STAPE, J.L.; BENEDETTI, V.; FESSEL, V.A.G.; GAVA, J.L. Reflexos do cultivo mínimo e intensivo do solo em sua fertilidade e na nutrição das árvores. In: GONÇALVES, J.L.M.; BENEDETTI, V. Nutrição e fertilização florestal. Piracicaba: IPEF, 2000. cap.1, p.1-57.

HÉNIN, S. Os solos agrícolas. São Paulo, EDUSP, 1976. 334 p.

HORN, R.; DEXTER, A.R. Dynamics of soil aggregation in an irrigated desert loess. Soil Tillage Research, v.13, p.253-266, 1989.

HOWARD, R.F.; SINGER, M.J.; FRANTZ, G.A. Effects of soil properties, water content, and compactive effort on the compaction of selected California forest and range soils. Soil Science Society of America Journal, v.45, p.231-236, 1981. 
KEMPER, D.; ROSENAU, R.C. Soil cohesion as affected by time and water content. Soil Science Society of America Journal, v.48, p.1001-1006, 1984.

KLUTE, A. Water retention: Laboratory Methods. In: KLUTE, A. Methods of soil analysis: physical and mineralogical methods. Madison: American Society of Agronomy, 1986. p.635-660.

LANÇAS, K.P. Subsolador: desempenho em função de formas geométricas de hastes, tipos de ponteiras e número de hastes. Botucatu, 1988. 171 p. Tese (Doutorado) Universidade Estadual Paulista “Júlio de Mesquita Filho”.

LANÇAS, K.P.; BENEZ, S.H. Avaliação dos resultados operacionais obtidos para três formas geométricas de hastes subsoladoras. Energia na Agricultura, v.4, n.1, p.2734, 1989.

McKYES, E. Soil cutting and tillage: Developments in agricultural engineering. Amsterdam: Elsevier Science Publishers, 1985. 217 p.

MIALHE, L.G. Máquinas agrícolas: ensaios \& certificação. Piracicaba: Fundação de Estudos Agrários Luiz de Queiroz (FEALQ), 1996. 722 p.

NICHOLS, M.L.; REED, I.F.; REAVES, C.A. Soil reaction to plowshare design. Agricultural Engineering, v.39, p.336-339, 1958.

OHU, J.O.; RAGHAVAN, G.S.V.; McKYES, E.; MEHUYS, G. Shear strength prediction of compacted soil with varying organic contents. Transactions of the ASAE, v.29, n 2, p 351-355, 1986.

OJENIYI, S.O.; DEXTER, A.R. Soil factors affecting the macrostructure produced by tillage. Transactions of the ASAE, v.22, n.2, p.339-343, 1979. 
OLIVEIRA, L.C.A. Comportamento de colóides e microagregados em colunas de materiais de dois Latossolos submetidos a sucessivos ciclos de umedecimento e secagem. Viçosa, 1994. 63 p. Dissertação (Mestrado) - Universidade Federal de Viçosa.

OLIVEIRA, T.S. Efeitos dos ciclos de umedecimento e secagem sobre propriedades físicas e químicas de quatro Latossolos brasileiros. Viçosa, 1992. 104 p. Dissertação (Mestrado) - Universidade Federal de Viçosa.

RAGHAVAN, G.S.V.; McKYES, E.; CHASSÉ, M.; MÉRINEAU, F. Development of compaction patterns due to machinery operation in an orchard soil. Canadian Journal of Plant Science, v.56, p.505-509, 1976.

RICHARDSON, S.J. Effect of artificial weathering cycles on the structural stability of a dispersed silt soil. Journal of Soil Science, v.27, p.287-294, 1976.

RÍPOLI, T.C.; MIALHE, L.G.; NAKAMURA, R.T. Subsolagem e subsoladores. Piracicaba: Centro Acadêmico Luiz de Queiroz - Departamento Editorial, 1985. 34 p.

ROSA JÚNIOR, E.J. Efeito de sistemas de manejo da cultura do milho (Zea mays L.) em um Latossolo Roxo na região de Dourados-MS. Botucatu, 2000. 112 p. Tese (Doutorado) - Universidade Estadual Paulista “Júlio de Mesquita Filho”.

SALIH, R.O.; MAULOOD, A.O. Influence of temperature and cycles of wetting and drying on modulus of rupture. Soil Tillage Research, v.11, p.73-80, 1988.

SASAKI, C.M. Força de tração e desempenho operacional de hastes subsoladoras em solos com diferentes texturas e umidade. Piracicaba, 2000. 53 p. Dissertação (Mestrado) - Escola Superior de Agricultura “Luiz de Queiroz”, Universidade de são Paulo. 
SASAKI, C.M.; BENTIVENHA, S.R.P.; GONÇALVES, J.L.M. Configurações básicas de subsoladores florestais. In: GONÇALVES, J.L.M.; STAPE, J.L. Conservação e cultivo de solos para plantações florestais. Piracicaba: IPEF, 2002. cap.12, p.393407.

SEIXAS, F. Efeitos físicos da colheita mecanizada de madeira sobre o solo. In: GONÇALVES, J.L.M.; STAPE, J.L. Conservação e cultivo de solos para plantações florestais. Piracicaba: IPEF, 2002. cap.9, p.313-350.

SIGMAPLOT software. Version 8.ed. SPSS, Chicago, 2002, 65p.

SILVA, A.P.; LIBARDI, P.L.; CAMARGO, O.A. Influência de compactação nas propriedades físicas de dois Latossolos. Revista Brasileira de Ciência do Solo, v.10, p.91-95, 1986.

SILVA, A.P.; FOLEGATTI, M.V.; VIDAL, P.T.; DEMATTE, J.L.I. Efeito da subsolagem em alguns atibutos físicos do solo em pomares de laranja no município de Matão-SP. In: CONGRESSO BRASILEIRO E ENCONTRO NACIONAL DE PESQUISA SOBRE CONSERVAÇÃO DO SOLO, 8. Londrina, 1990. Anais. Londrina: Sociedade Brasileira de Ciência do Solo, 1990, p.86.

SILVA, A.P.; IMHOFF, S.C.; TORMENA, C.A.; LEÃO, T.P. Avaliação da compactação de solos florestais. In: GONÇALVES, J.L.M.; STAPE, J.L. Conservação e cultivo de solos para plantações florestais. Piracicaba: IPEF, 2002a. cap.10, p.351-372.

SILVA, C.R.; CAMARGO, F.R.A.; JACOB, W.S.; IIJIMA, J. Preparo de solos em áreas acidentadas do Vale do Paraíba do Sul-SP. In: GONÇALVES, J.L.M.; STAPE, J.L. Conservação e cultivo de solos para plantações florestais. Piracicaba: IPEF, 2002b. cap.6, p.245-260. 
SILVEIRA, G.M. O preparo do solo: implementos corretos. Rio de Janeiro: Globo, 1988. 243 p.

SIMÕES, J.W.; BRANDI, R.M.; LEITE, N.B.; BALLONI, E.A. Formação, manejo e exploração de florestas com espécies de rápido crescimento. Brasília: Instituto Brasileiro de Desenvolvimento Florestal, 1981. 131 p.

SOULIDES, D.A.; ALLISON, F.E. Effect of drying and freezing soils on carbon dioxide production, available mineral nutrients, aggregation and bacterial population. Soil Science, v.91, p.291-298, 1961.

SOUZA, A.J. Preparo de solos coesos para cultura do eucalipto no extremo sul da Bahia. In: GONÇALVES, J.L.M.; STAPE, J.L. Conservação e cultivo de solos para plantações florestais. Piracicaba: IPEF, 2002. cap.8, p.297-311.

SPOOR, G.; GODWIN, R.J. An experimental investigation into the deep loosening of soil by rigid tines. Journal of Agricultural Engineering Research, v.23, p.243258, 1978.

SRIVASTAVA, A. K.; GOERING, C. E.; ROHRBACH, R. P. Engineering principles of agricultural machines. Michigan: American Society of Agricultural Engineers ASAE, 1993. $602 \mathrm{p}$.

STAFFORD, J.V. The performance of a rigid tine in relation to soil properties and speed. Journal of Agricultural Engineering Research, v.24, p.41-55, 1979.

STANCATI, G.; NOGUEIRA, J.B.; VILAR, O.M. Ensaios de laboratórios em mecânica de solos. São Carlos: Universidade de São Paulo, Escola de Engenharia de São Carlos, 1981. 208 p. 
STAPE, J.L.; ANDRADE, S.; GOMES, A.N.; KREJCI, L. C.; RIBEIRO, J. A. Definição de métodos de preparo de solo para silvicultura em solos coesos do litoral norte da Bahia. In: GONÇALVES, J.L.M.; STAPE, J.L. Conservação e cultivo de solos para plantações florestais. Piracicaba: IPEF, 2002. cap.7, p.259-296.

STATGRAPHICS PLUS. Version 1.4 ed. Statistical Graphics Corp., Rockville-MD, 1995.

STOLF, R.; FERNANDES, J.; FURLANI NETO, V. Penetrômetro de impacto modelo IAA/PLANALSUCAR: recomendações para seu uso. Araras: Instituto do Açúcar e do Álcool, 1982. 19 p.

TAYLOR, J.C.; BELTRAME, L.F.S. Por que, quando e como utilizar a subsolagem. Lavoura Arrozeira, v.3, p.34-44, 1980.

TORMENA, C.A.; SILVA, A.P.; LIBARDI, P.L. Caracterização do intervalo hídrico ótimo de um Latossolo Roxo sob plantio direto. Revista Brasileira de Ciência do Solo, v.22, p.573-581, 1998.

UTOMO, W.H.; DEXTER, H.P. Age hardening of agricultural top soils. Journal of Soil Science, v.32, p.335-350, 1981.

UTOMO, W.H.; DEXTER, H.P. Changes in soil aggregate stability induced by wetting and drying cycles in non-saturated soil. Journal of Soil Science, v.33, p.623-637, 1982.

VITAL, A.R.T.; LIMA, W.P.; POGGIANI, F.; CAMARGO, F.R.A. Biogeoquímica de uma microbacia após o corte raso de plantação de eucalipto de 7 anos de idade. Scientia Forestalis, v.55, p.17-28, 1999. 
VOORHEES, W.B.; SENST, C.G.; NELSON, W.W. Compaction and soil structure modification by wheel traffic in the Northern Corn Belt. Soil Science Society of America Journal, v.42, p.344-349, 1978.

YSHIMINE, P. Avaliação de algumas forças que atuam em um subsolador utilizado no preparo de solo agrícola. Botucatu, 1993. 94 p. Tese (Doutorado) - Universidade Estadual Paulista “Júlio de Mesquita Filho”.

ZEN, S.; YONEZAWA, J.T.; FELDEBERG, J.E. Implantação de florestas no sistema de cultivo mínimo. In: SEMINÁRIO SOBRE CULTIVO MÍNIMO DO SOLO EM FLORESTAS, 1. Curitiba, 1995. Anais. Curitiba: CNPFlorestas/IPEF/UNESP/SIF/ FUPEF, 1995. p.65-72. 
ANEXOS 
ANEXO A - Área mobilizada de solo para o LVd-1 $\left(\theta=0,079 \mathrm{~cm}^{3} \mathrm{~cm}^{-3}\right)$
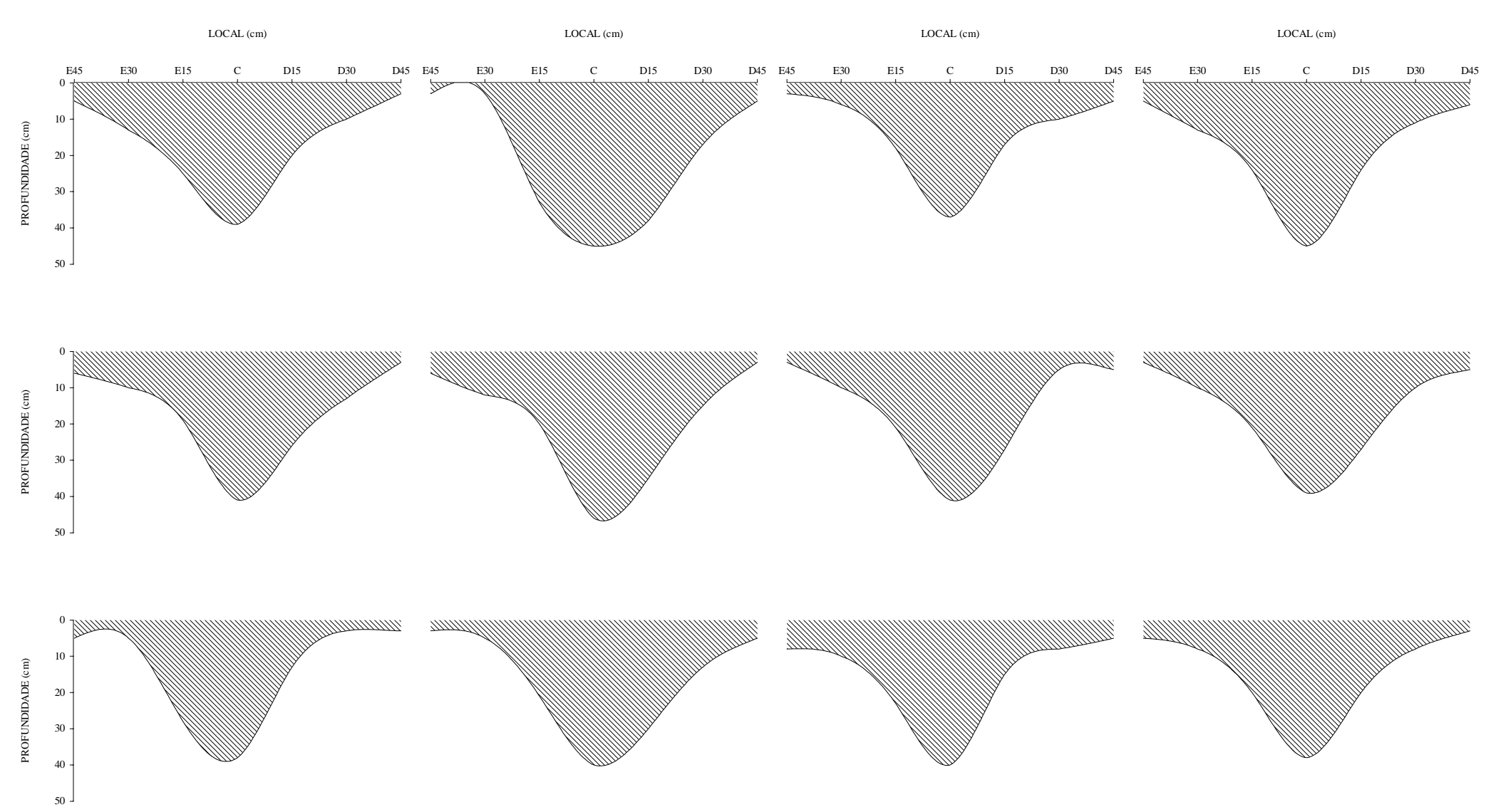
ANEXO B - Área mobilizada de solo para o LVd-1 $\left(\theta=0,087 \mathrm{~cm}^{3} \mathrm{~cm}^{-3}\right)$
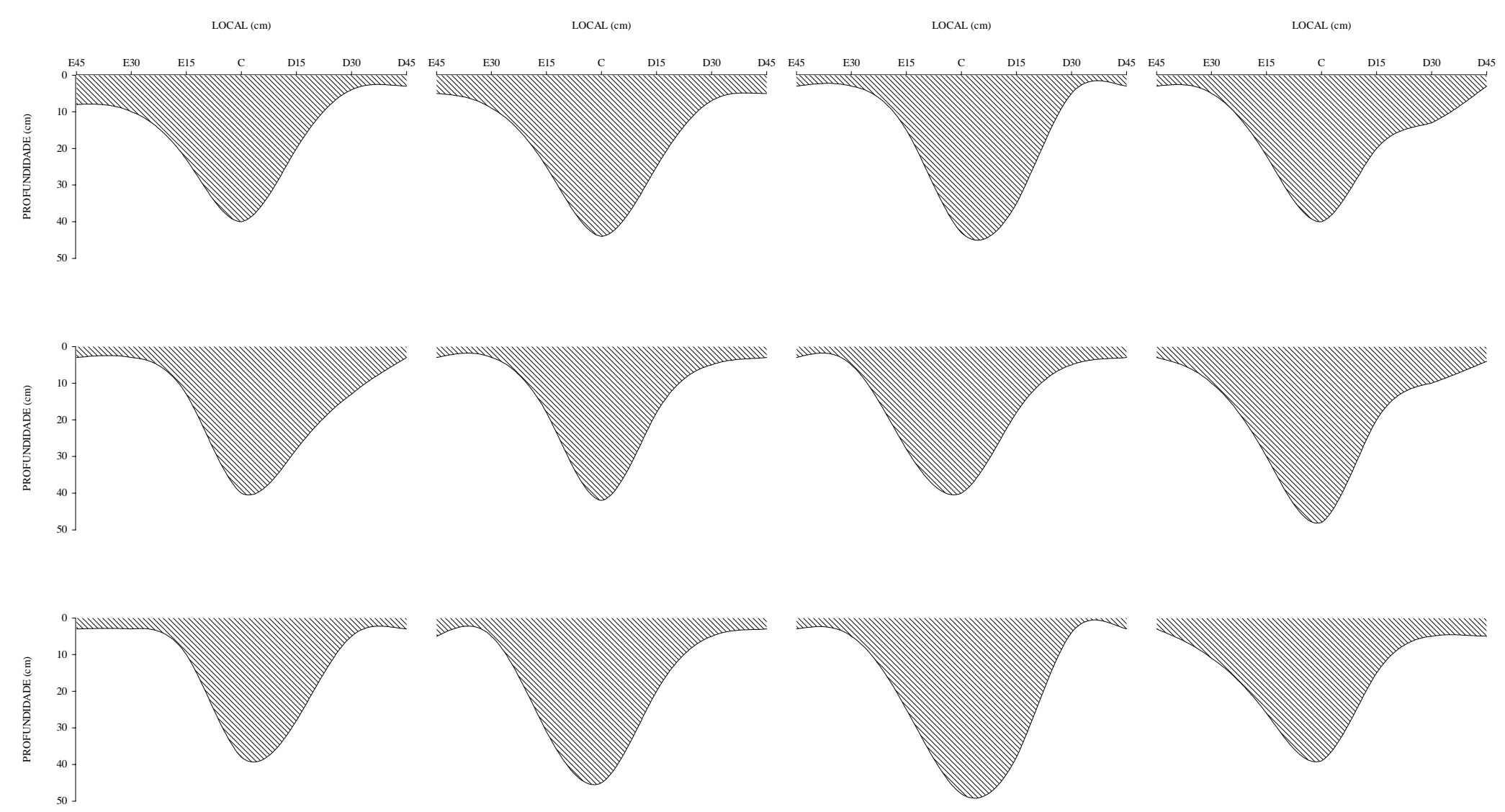
ANEXO C - Área mobilizada de solo para o LVd-1 $\left(\theta=0,102 \mathrm{~cm}^{3} \mathrm{~cm}^{-3}\right)$
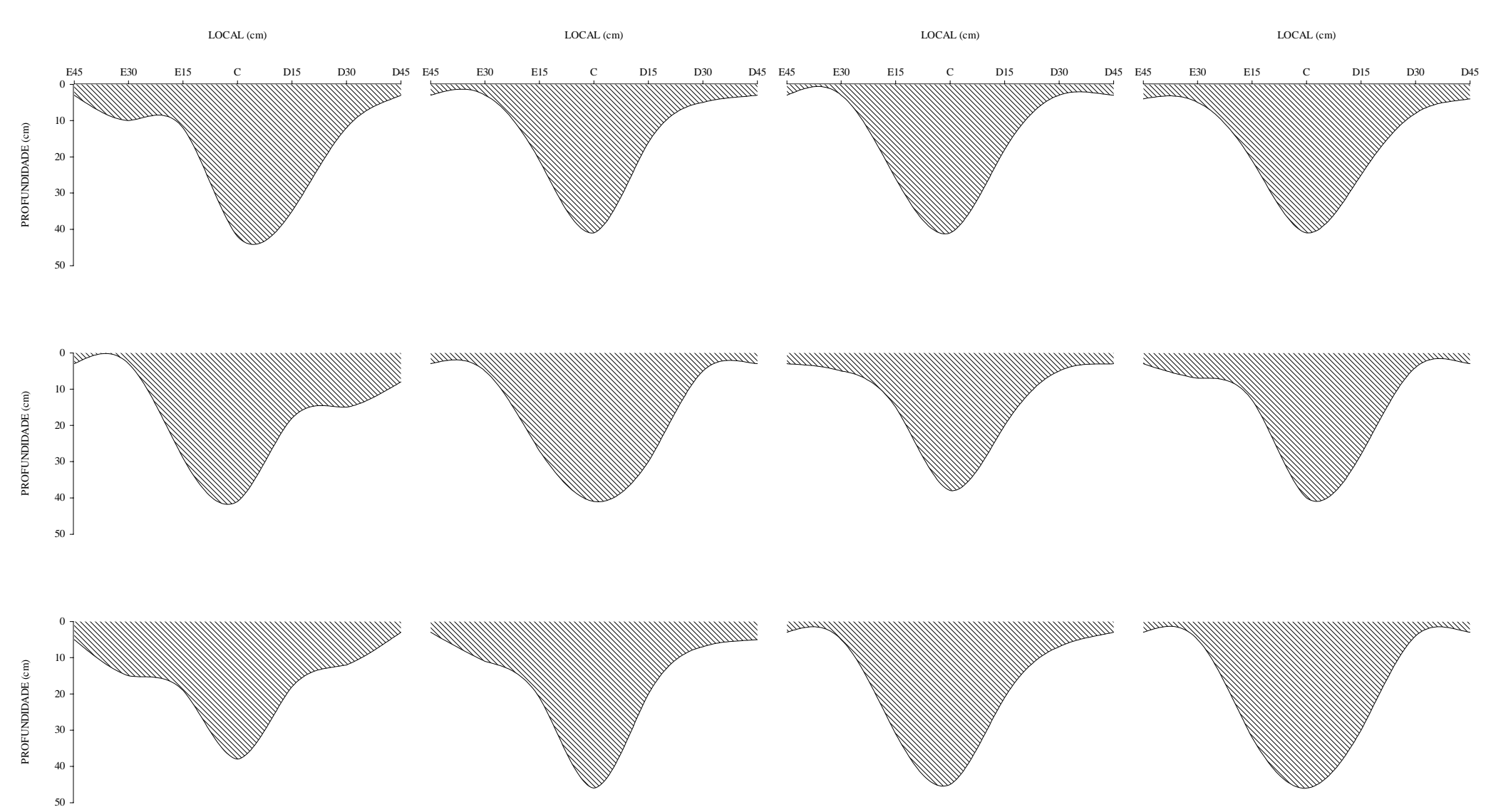


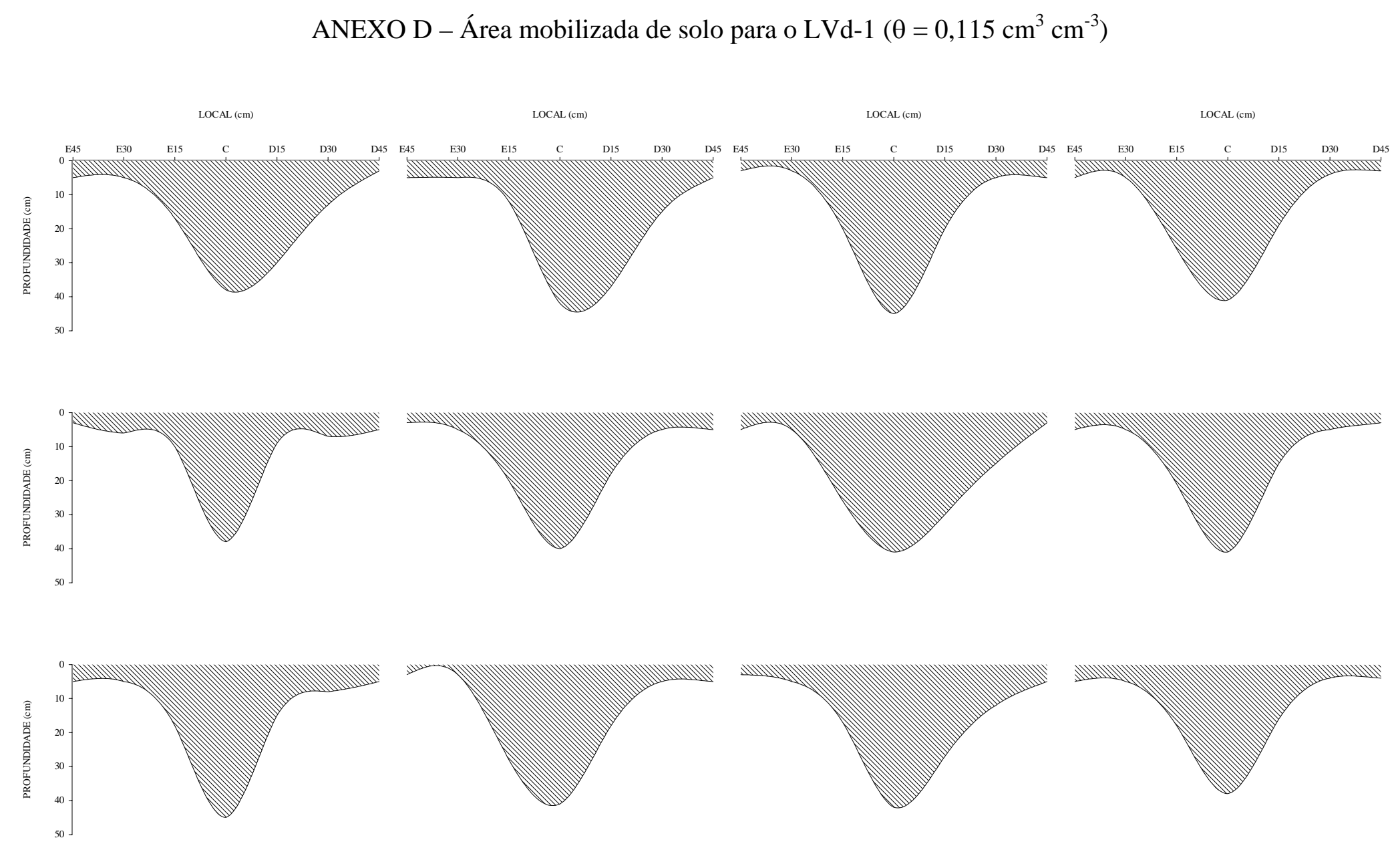




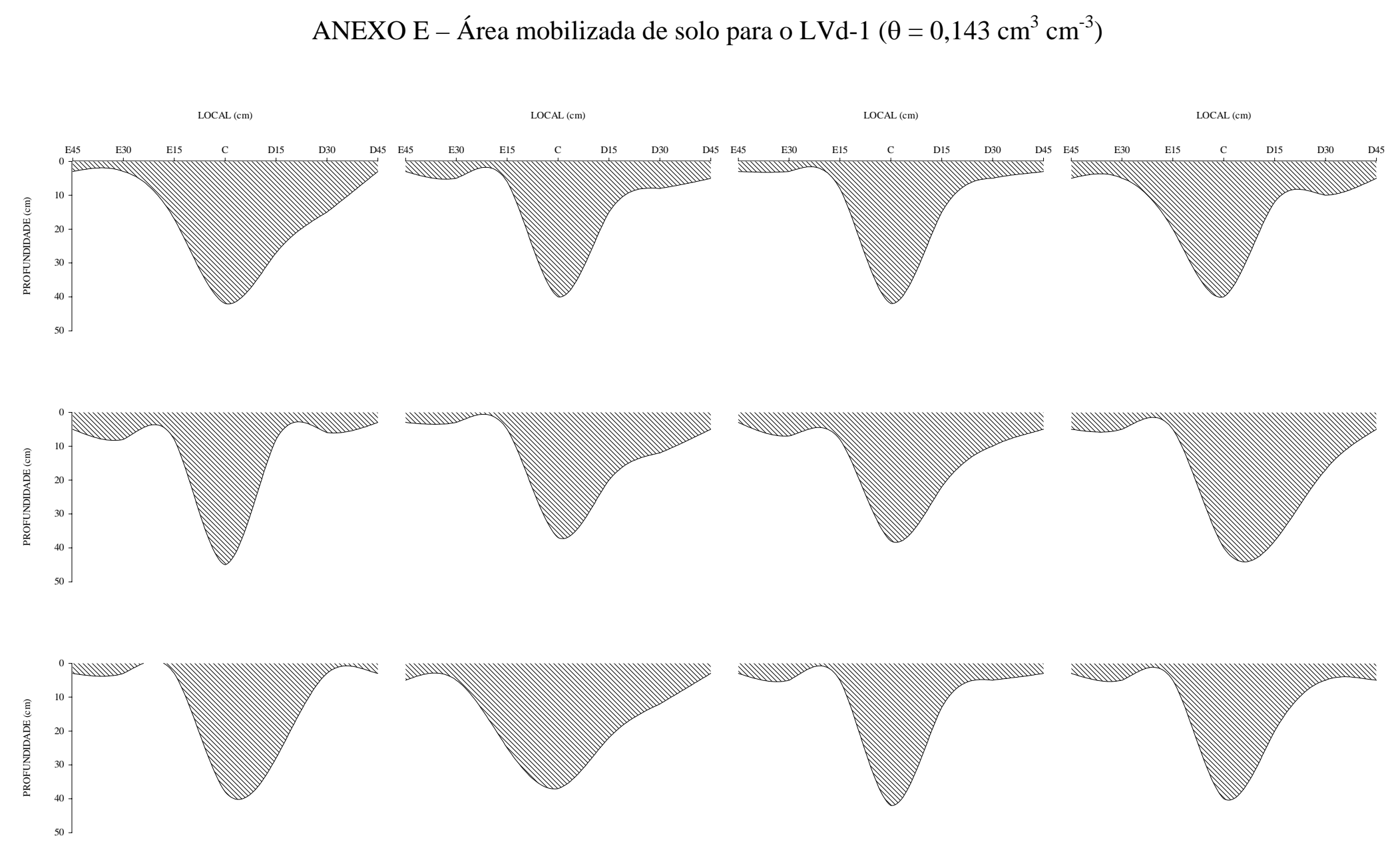


ANEXO F - Área mobilizada de solo para o LVd-2 $\left(\theta=0,127 \mathrm{~cm}^{3} \mathrm{~cm}^{-3}\right)$
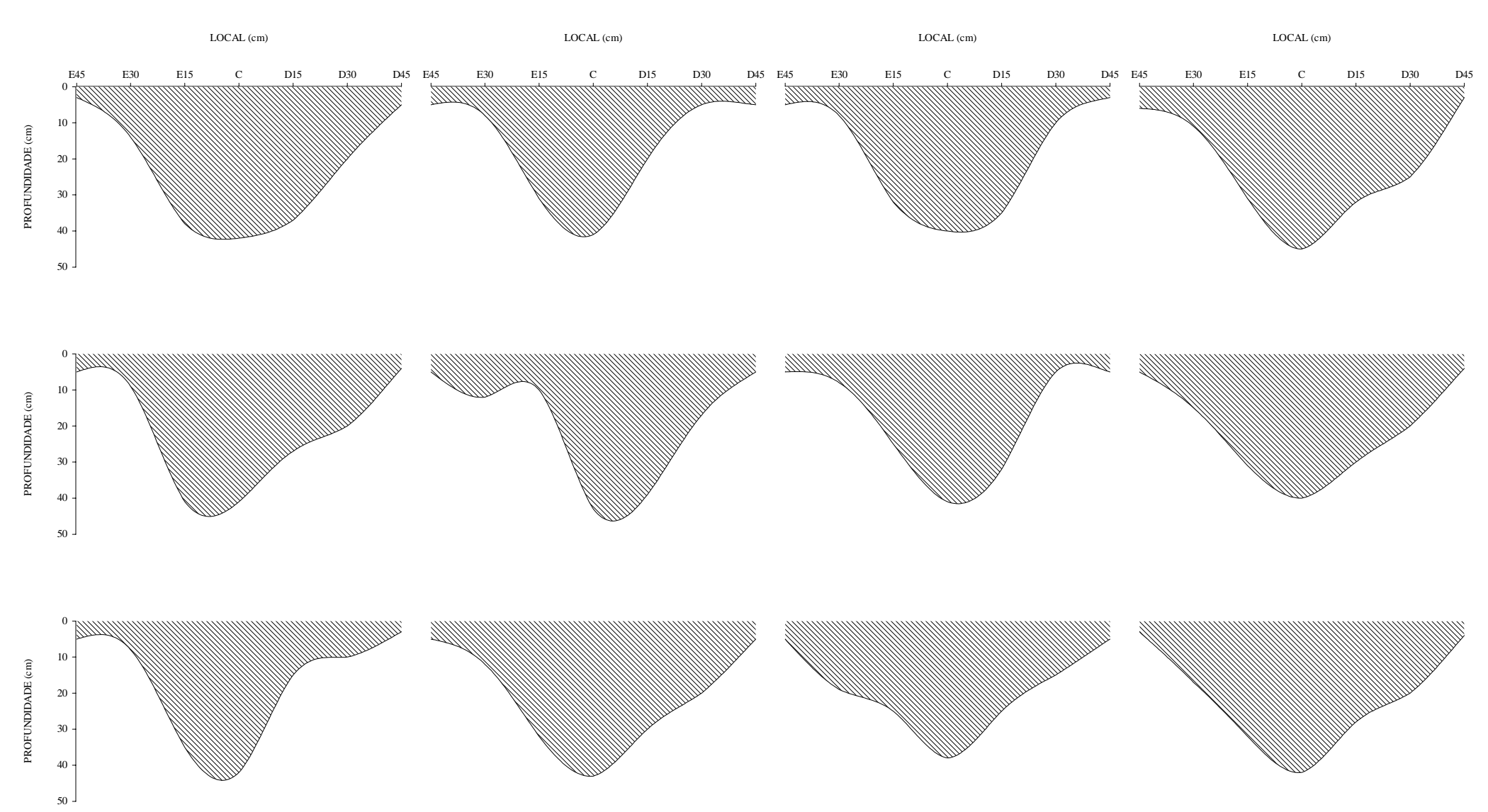
ANEXO G - Área mobilizada de solo para o LVd-2 $\left(\theta=0,152 \mathrm{~cm}^{3} \mathrm{~cm}^{-3}\right)$
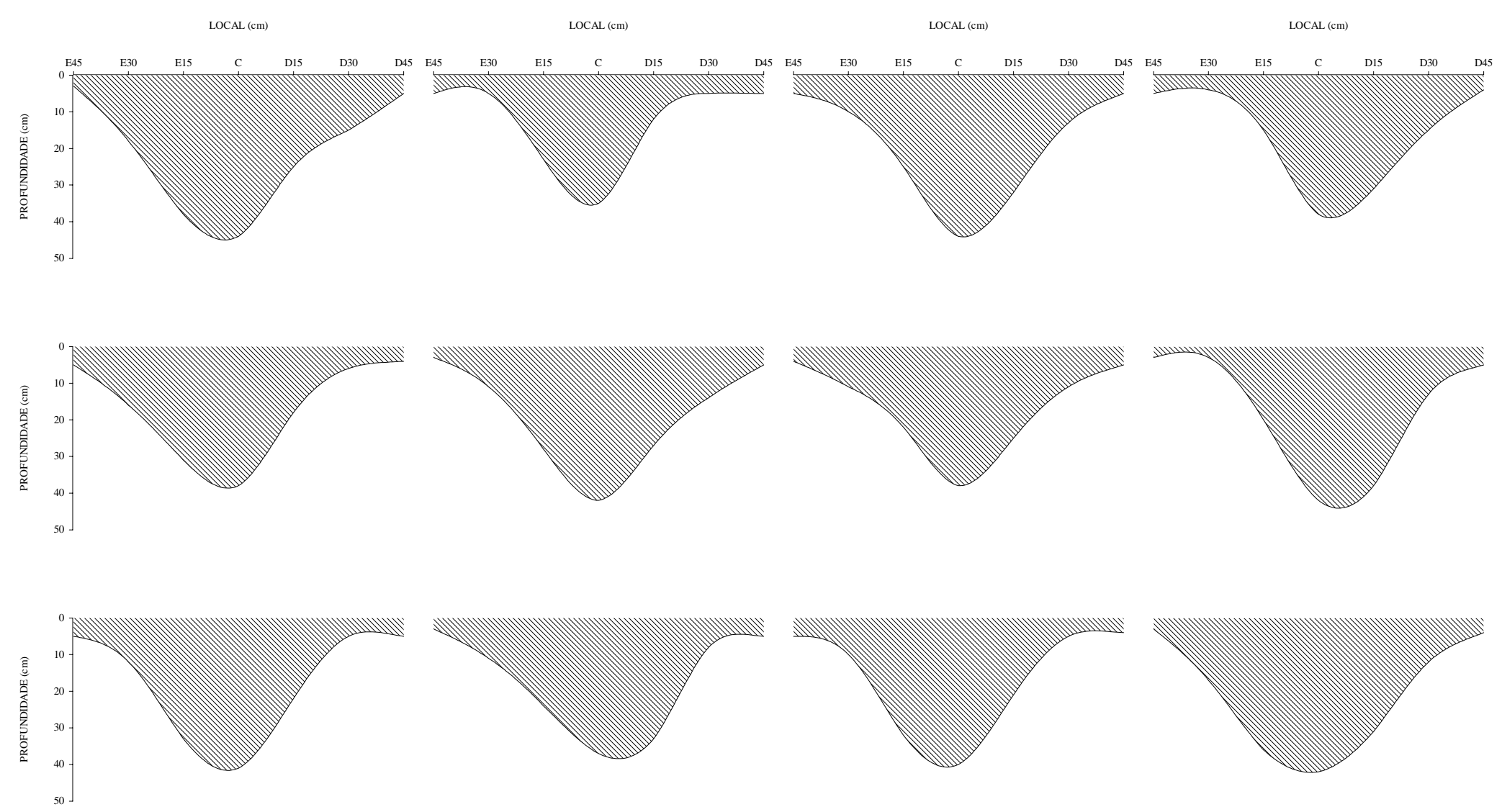
ANEXO H - Área mobilizada de solo para o LVd-2 $\left(\theta=0,161 \mathrm{~cm}^{3} \mathrm{~cm}^{-3}\right)$
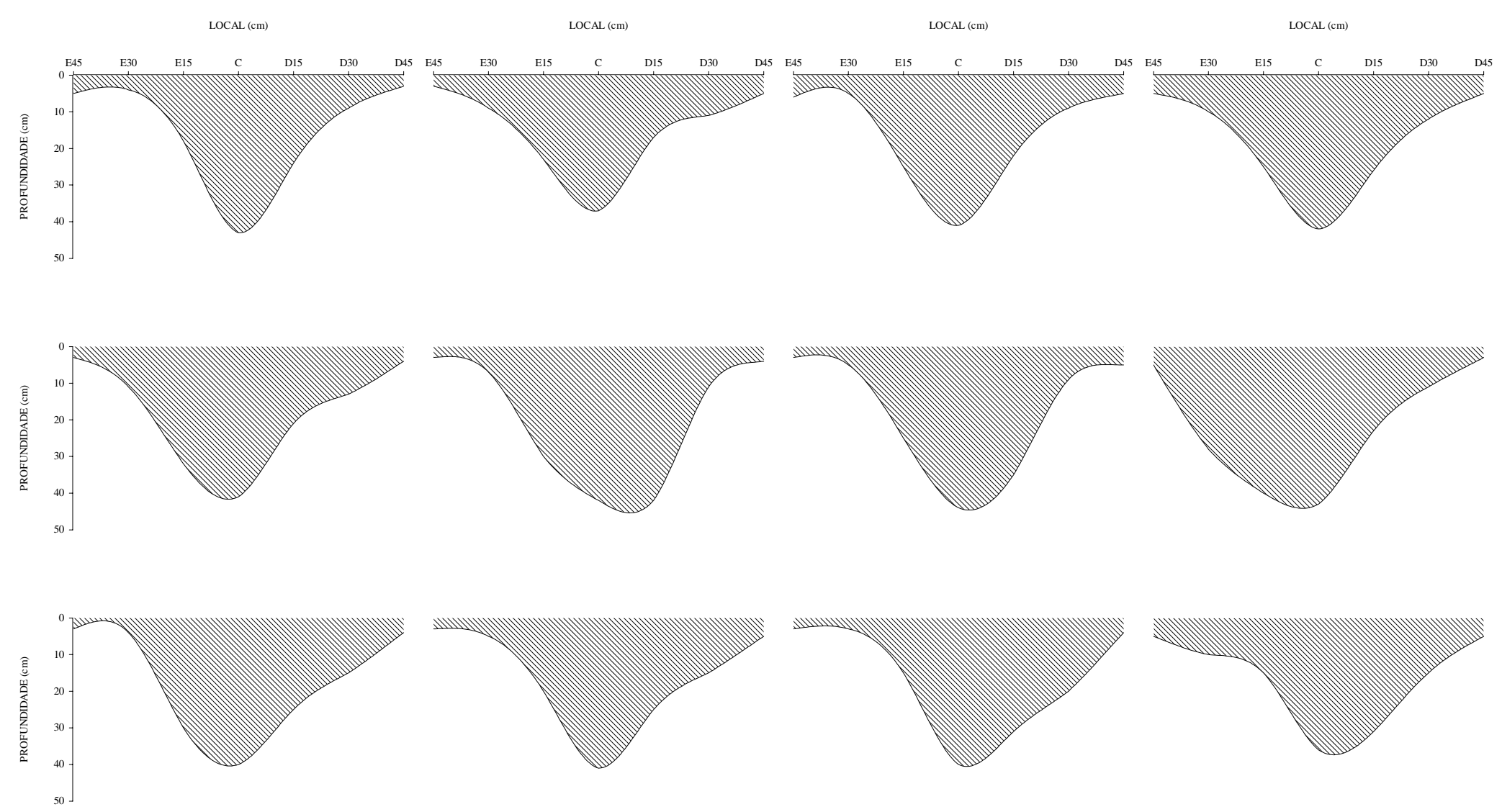


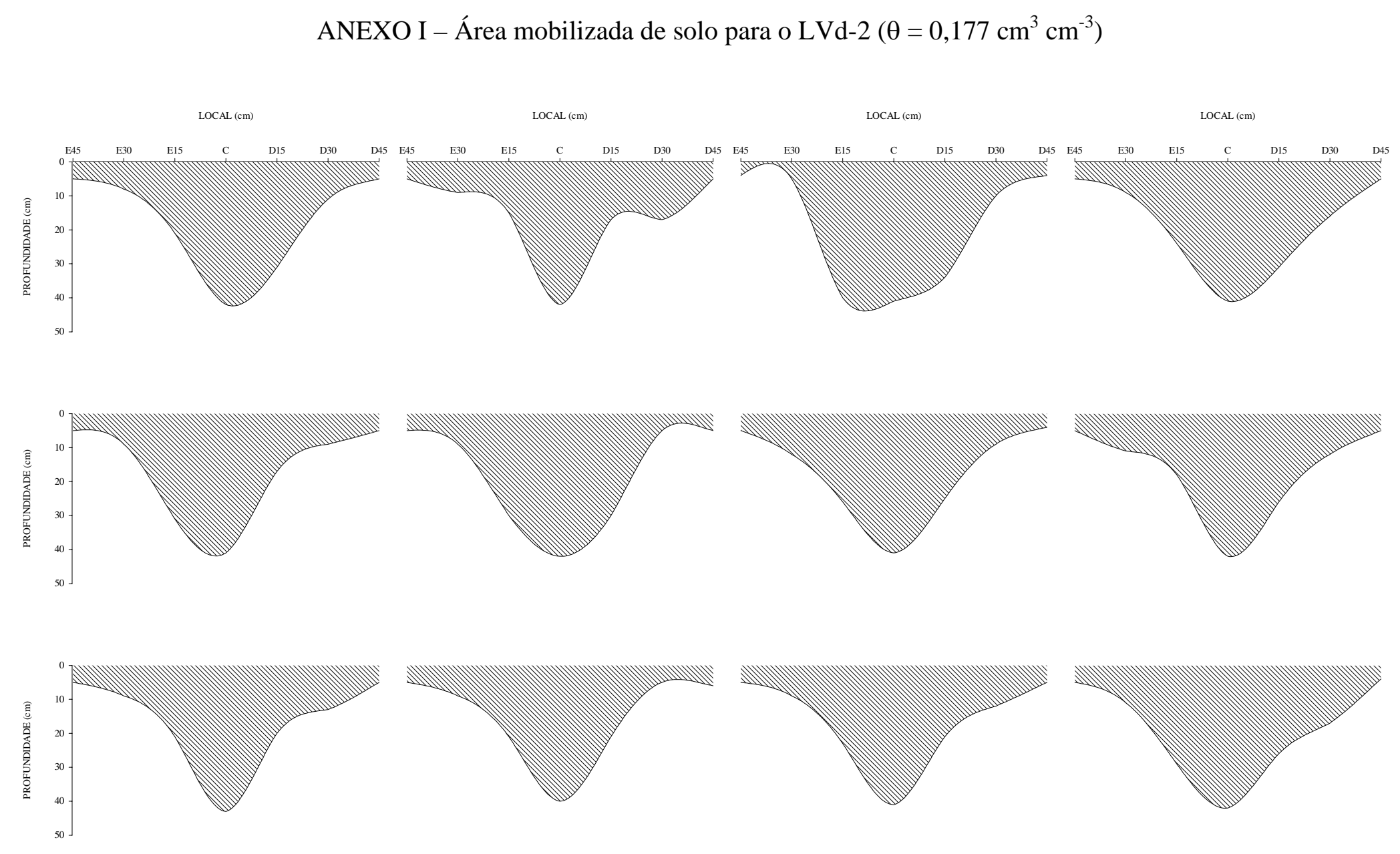


ANEXO J - Área mobilizada de solo para o LVd-2 $\left(\theta=0,213 \mathrm{~cm}^{3} \mathrm{~cm}^{-3}\right)$
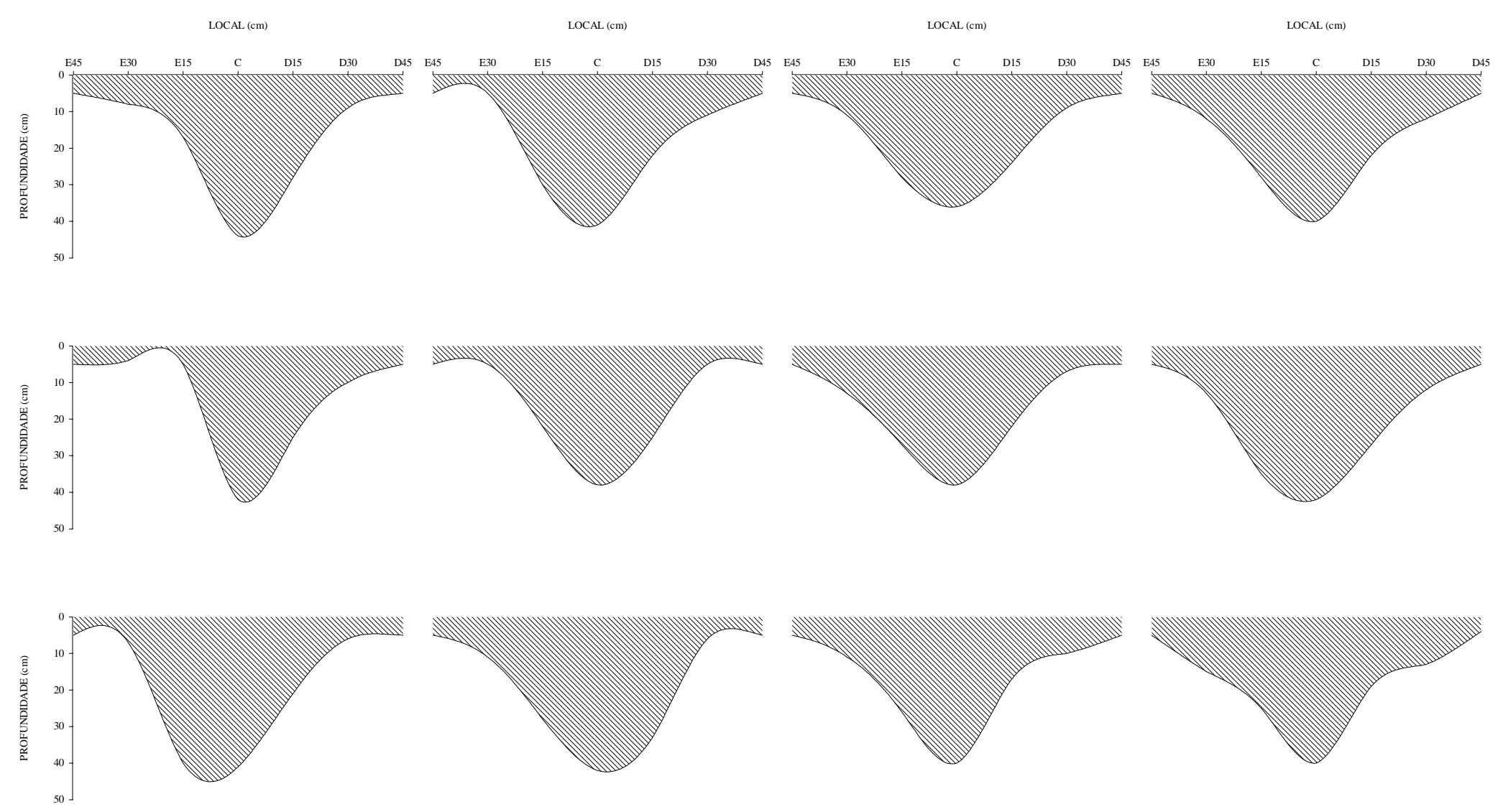


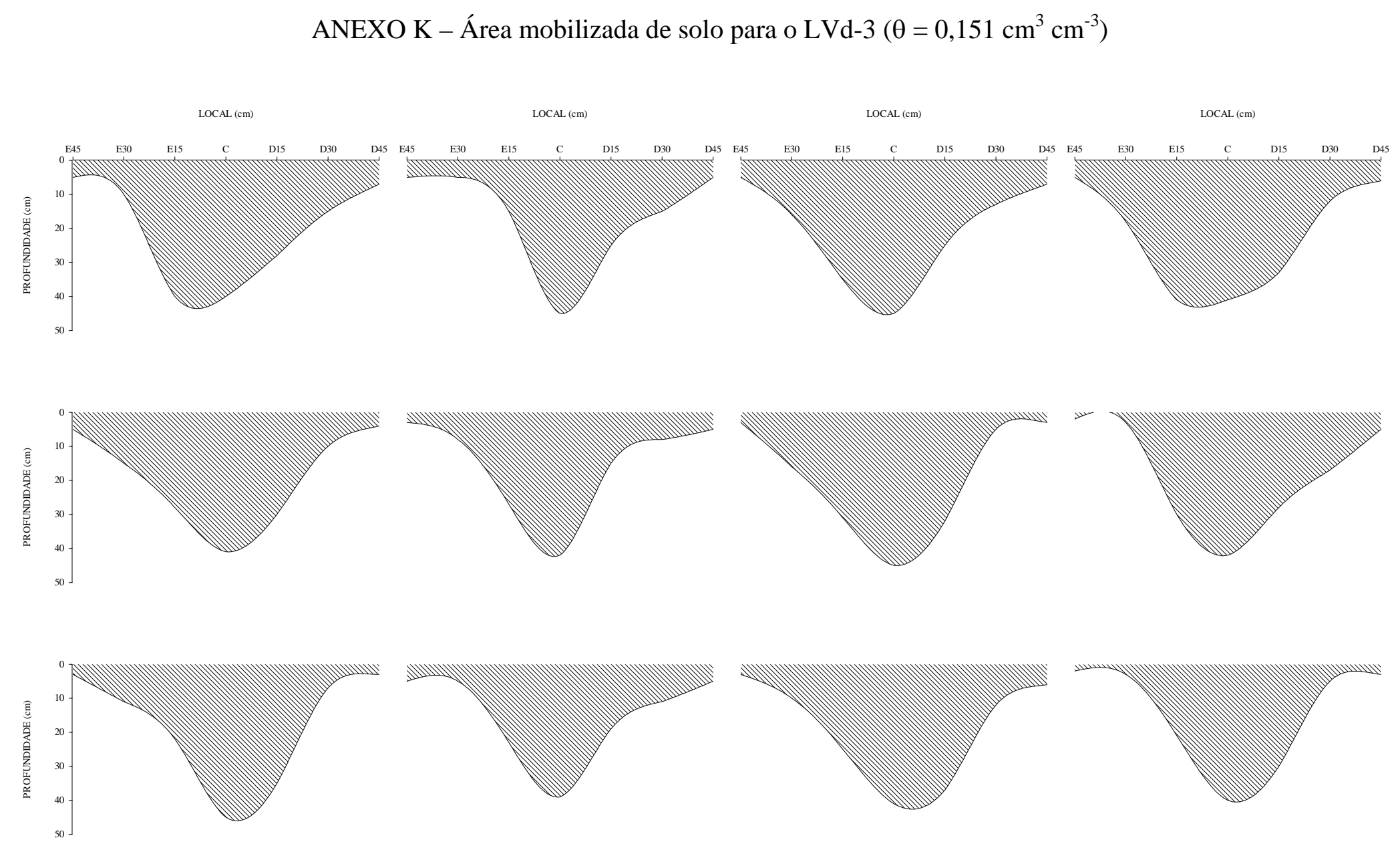


ANEXO L - Área mobilizada de solo para o LVd-3 $\left(\theta=0,192 \mathrm{~cm}^{3} \mathrm{~cm}^{-3}\right)$
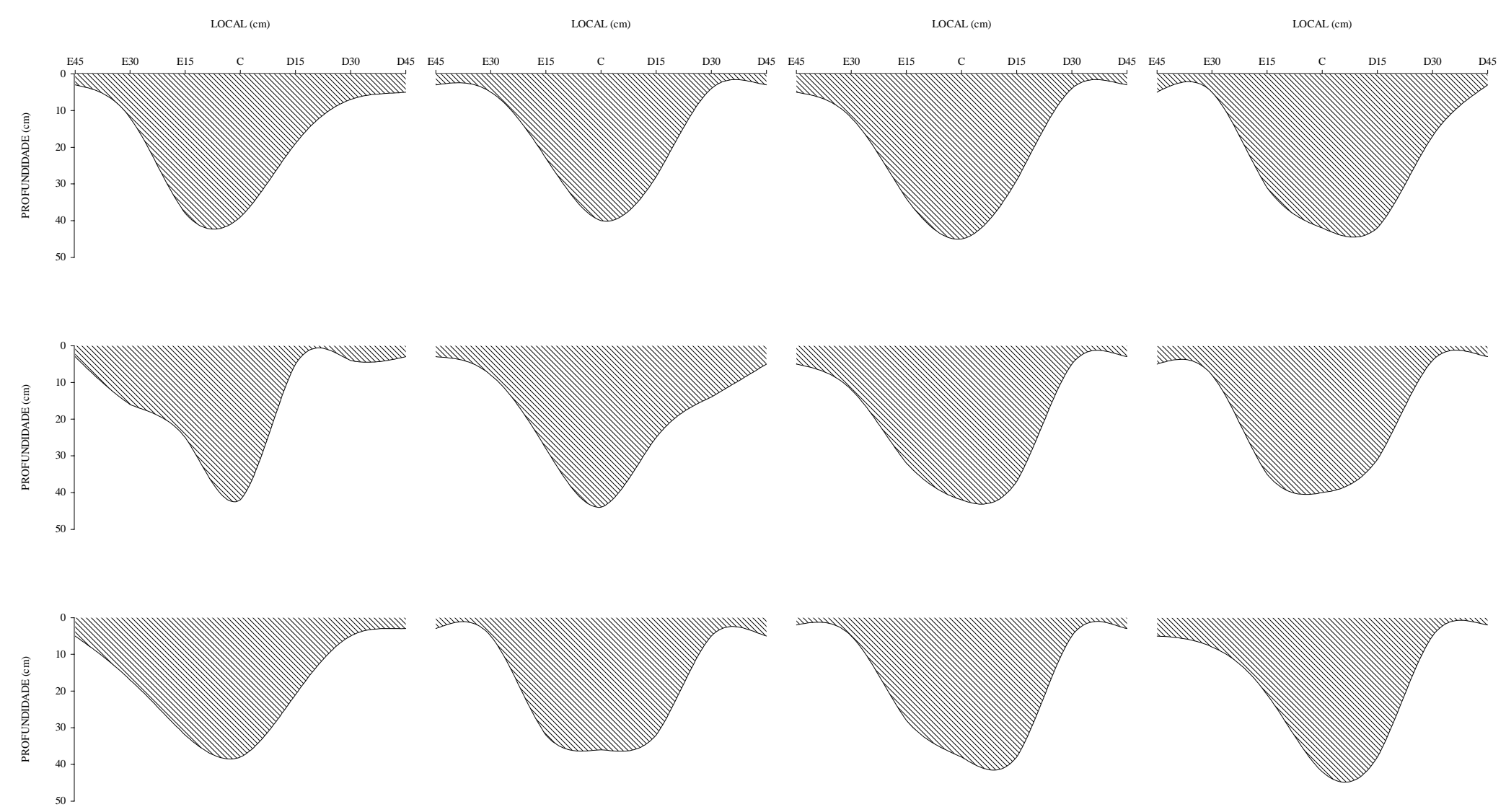
ANEXO M - Área mobilizada de solo para o LVd-3 $\left(\theta=0,227 \mathrm{~cm}^{3} \mathrm{~cm}^{-3}\right)$
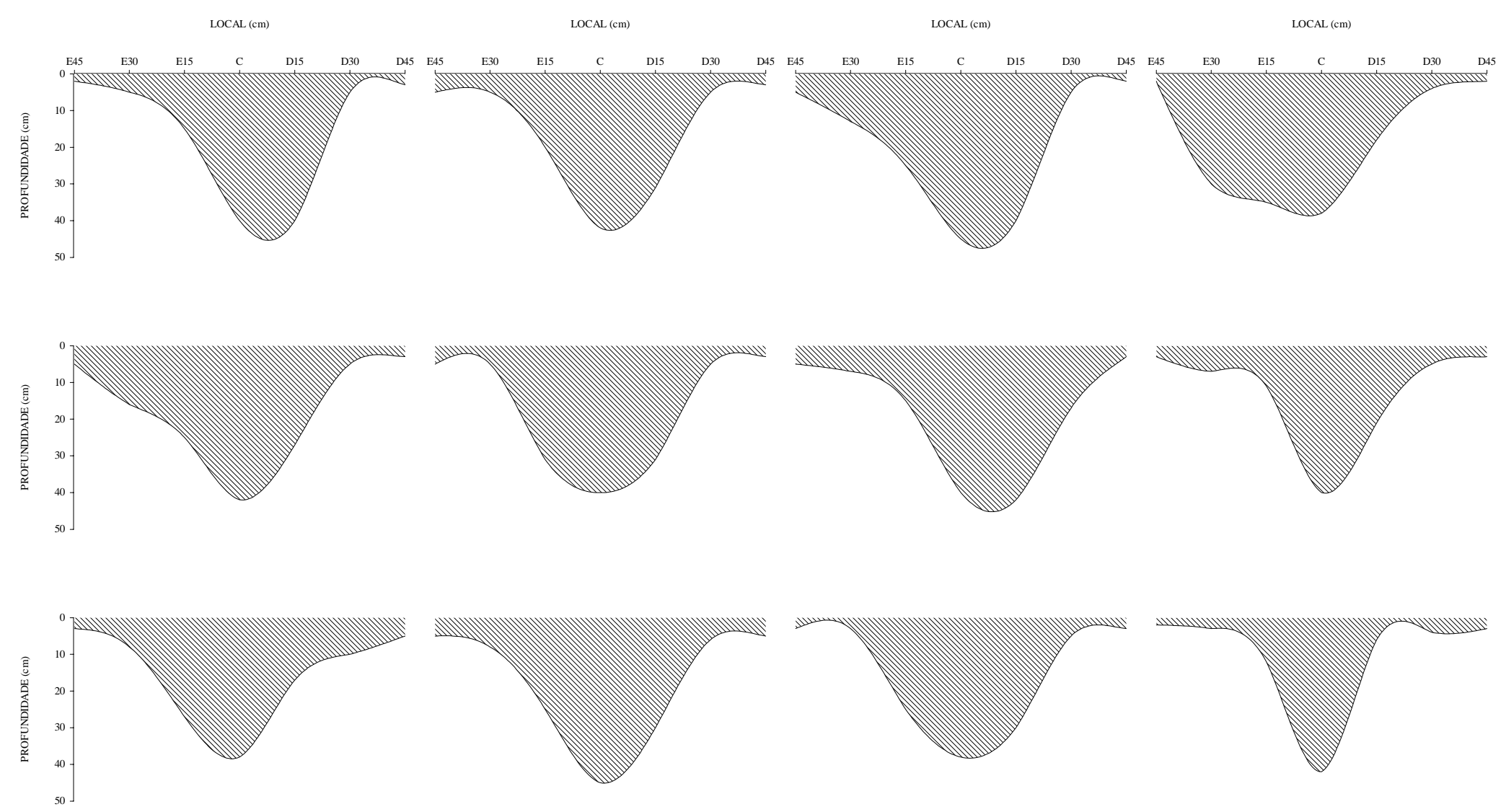
ANEXO N - Área mobilizada de solo para o LVd-3 $\left(\theta=0,273 \mathrm{~cm}^{3} \mathrm{~cm}^{-3}\right)$
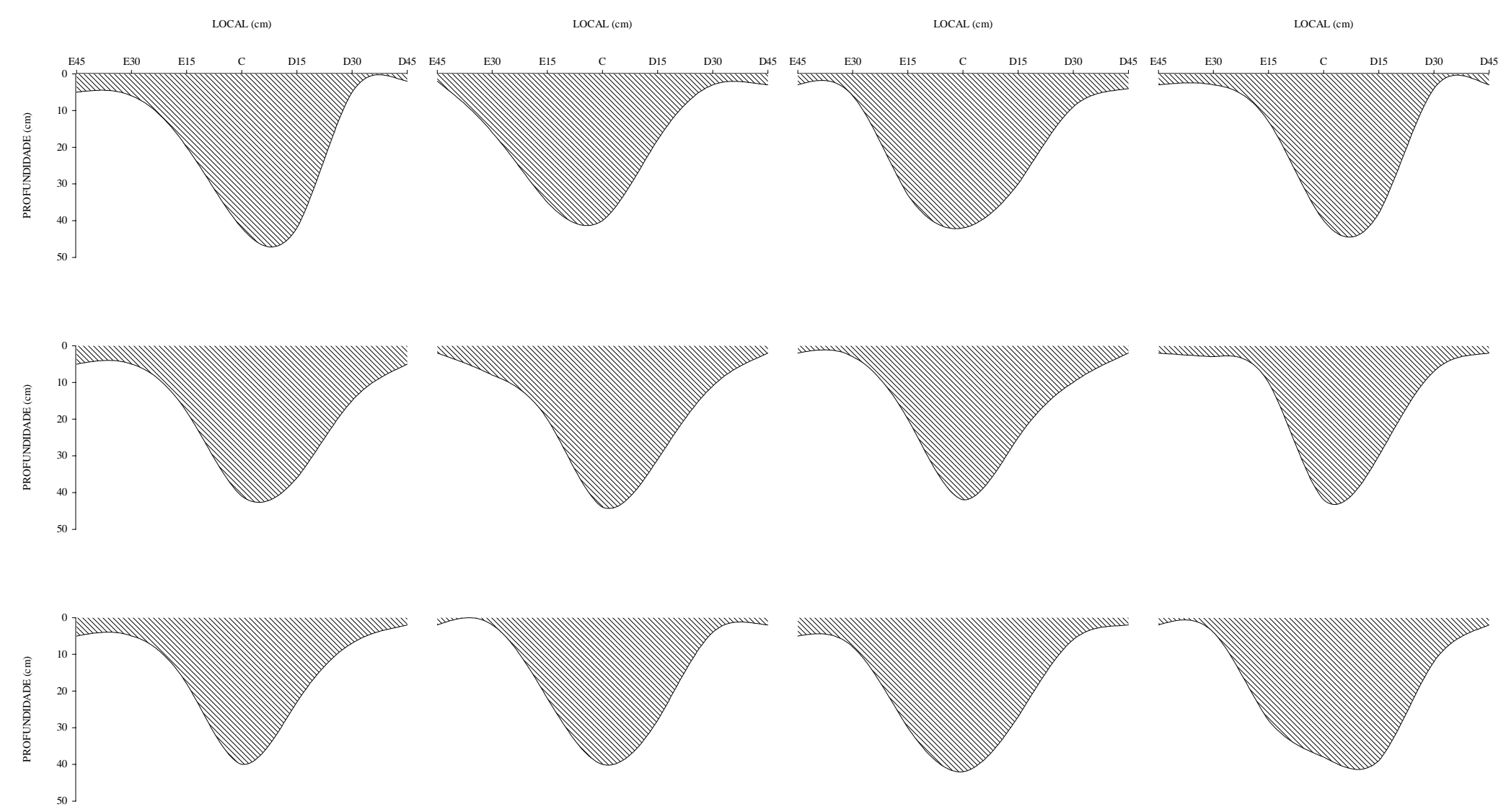


$$
\text { ANEXO O - Área mobilizada de solo para o LVd-3 }\left(\theta=0,322 \mathrm{~cm}^{3} \mathrm{~cm}^{-3}\right)
$$
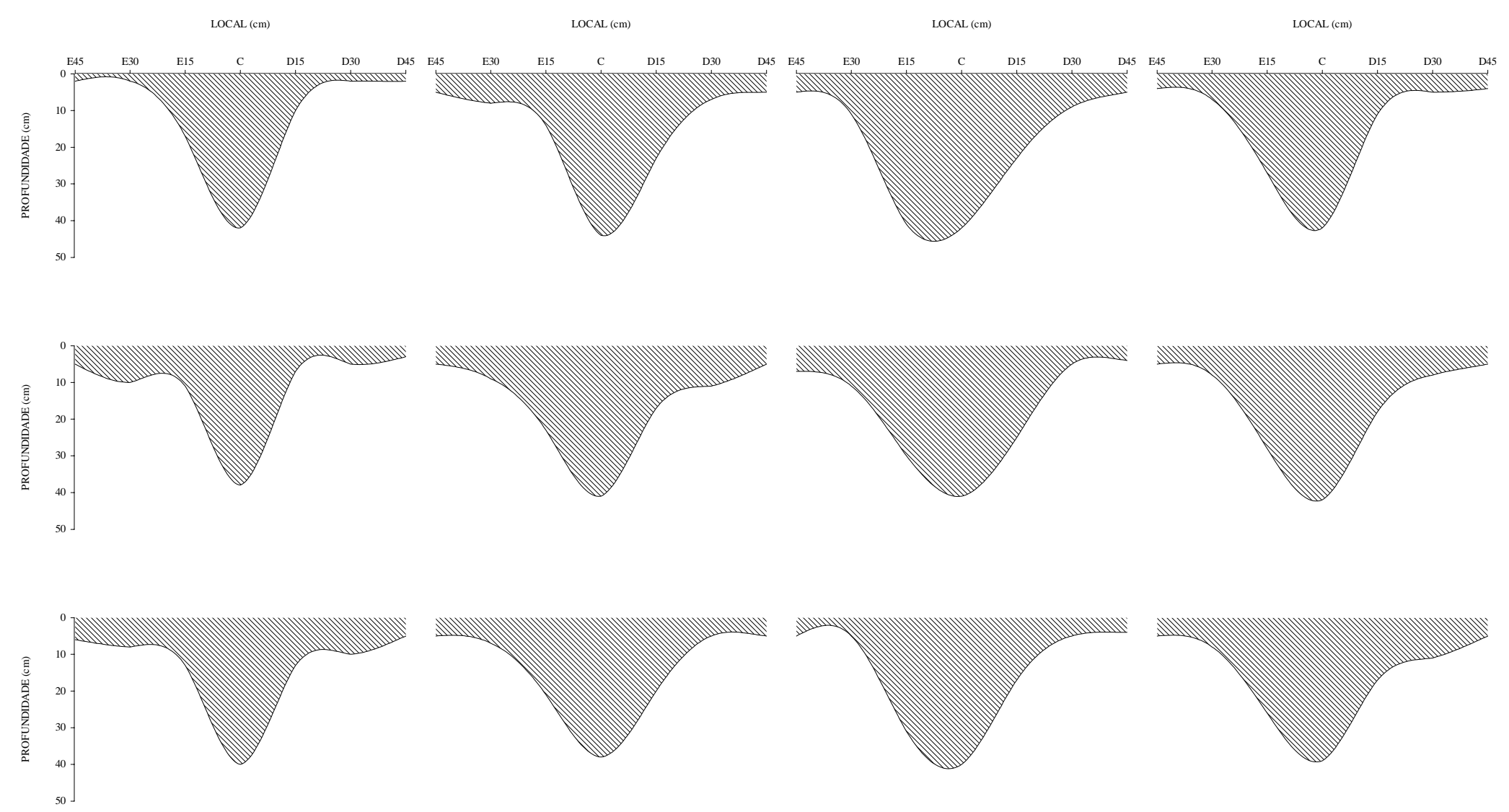
ANEXO P - Re-adensamento do sulco de preparo do LVd-1 (pós-preparo; $\theta=0,102 \mathrm{~cm}^{3} \mathrm{~cm}^{-3}$ )
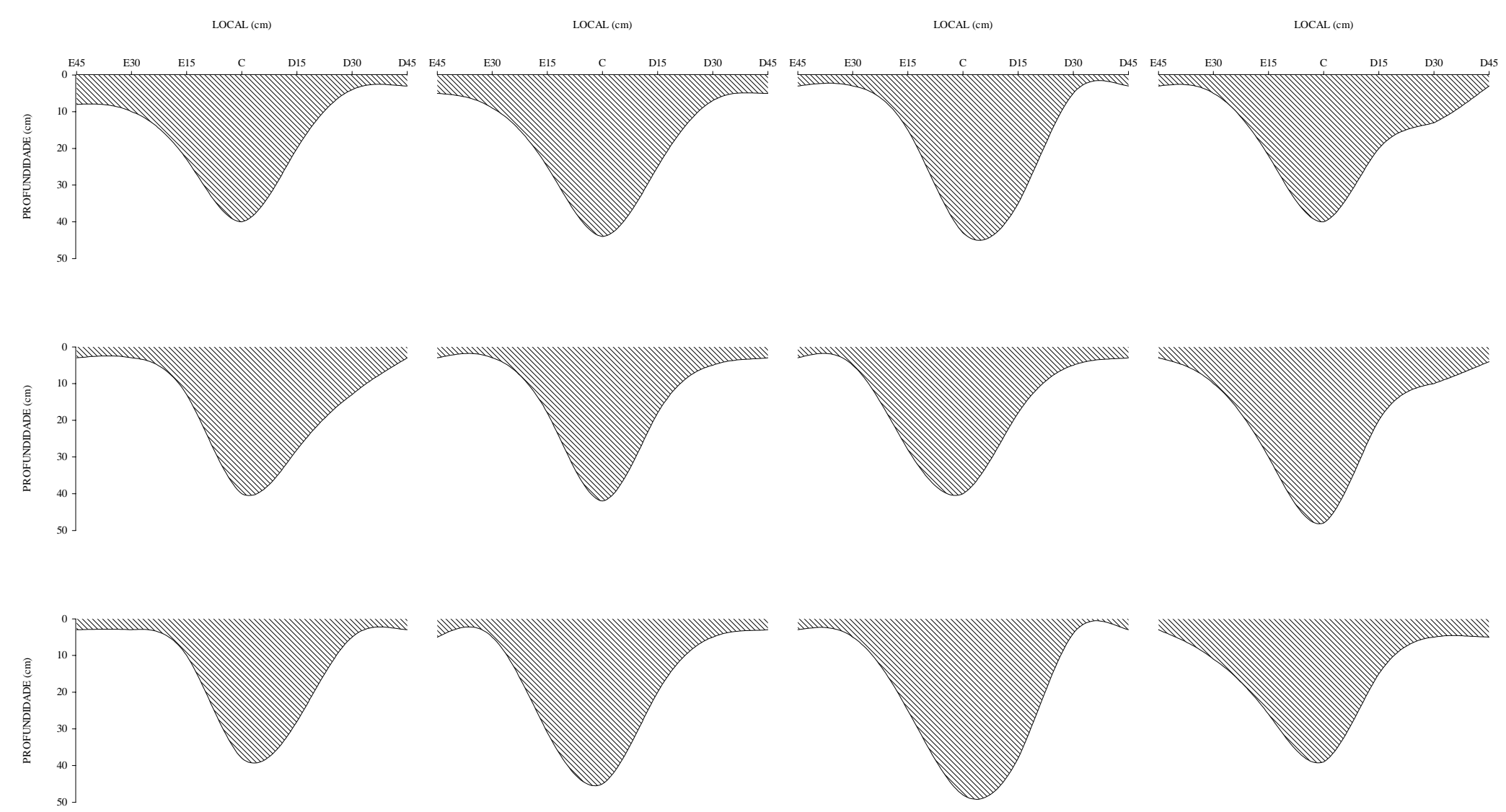
ANEXO Q - Re-adensamento do sulco de preparo do LVd-1 (12 meses pós-preparo; $\theta=0,111 \mathrm{~cm}^{3} \mathrm{~cm}^{-3}$ )
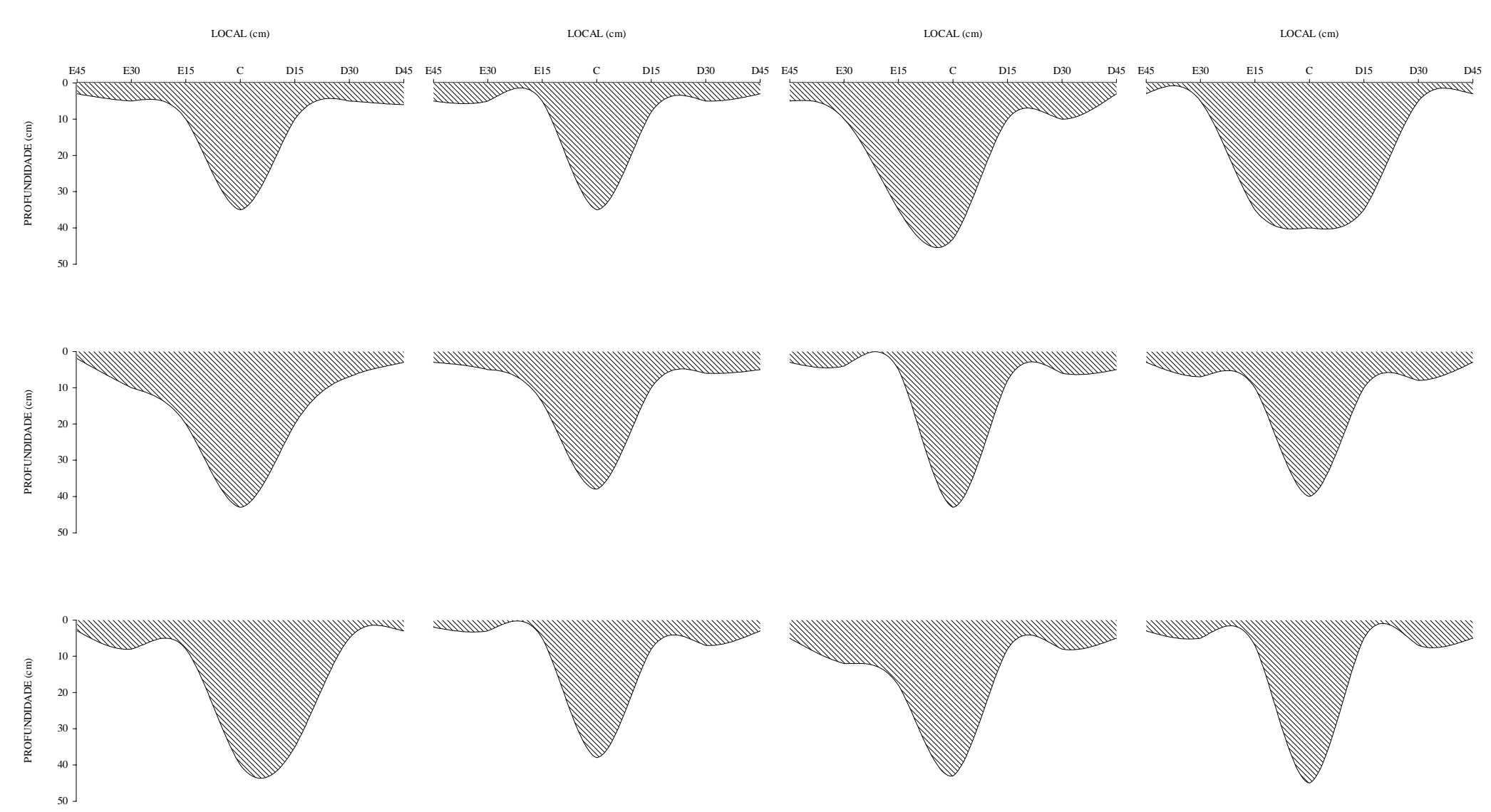
ANEXO R - Re-adensamento do sulco de preparo do LVd-1 (24 meses pós-preparo; $\theta=0,096 \mathrm{~cm}^{3} \mathrm{~cm}^{-3}$ )
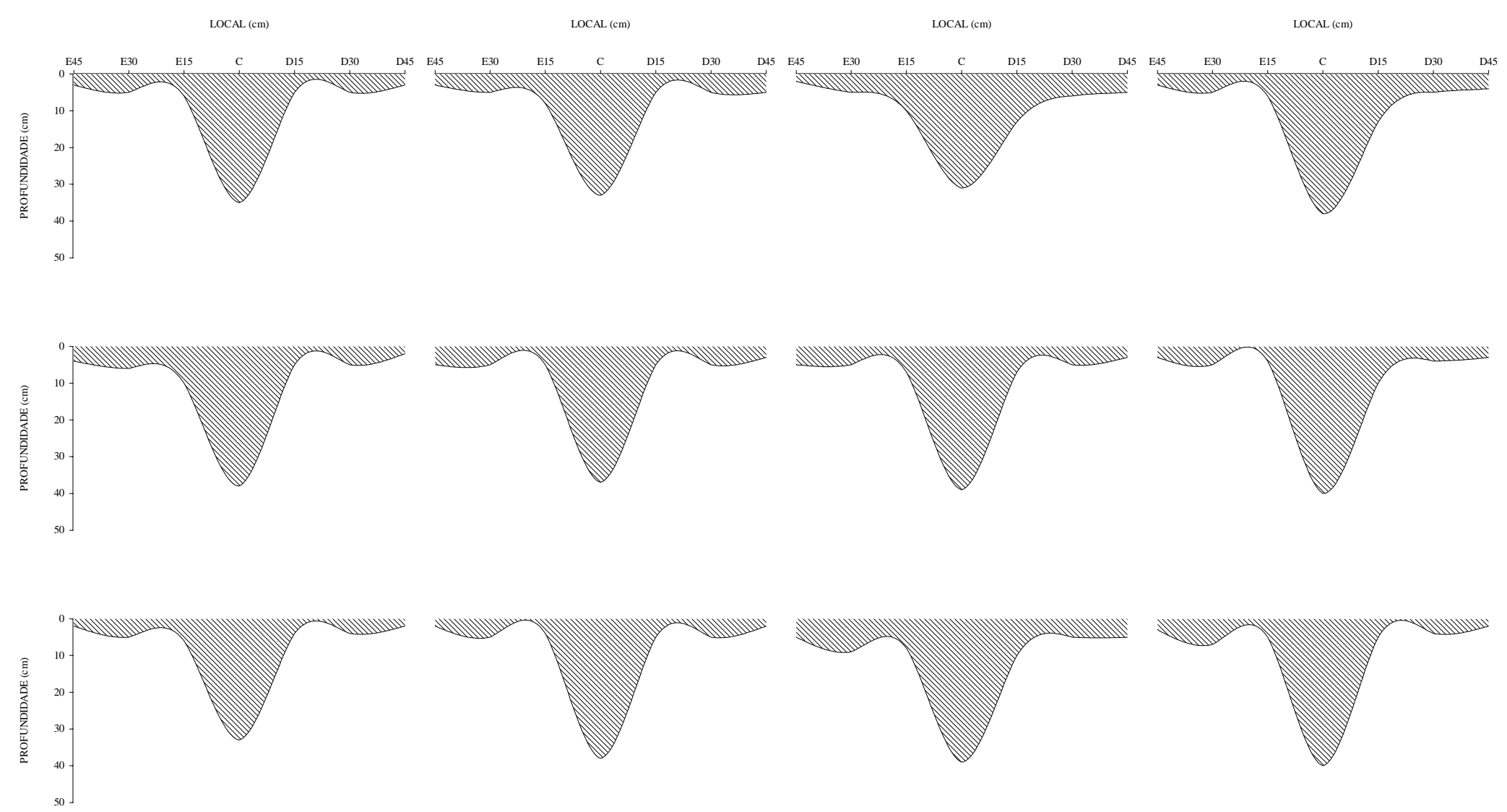
ANEXO S - Re-adensamento do sulco de preparo do LVd-2 (pós-preparo; $\theta=0,161 \mathrm{~cm}^{3} \mathrm{~cm}^{-3}$ )
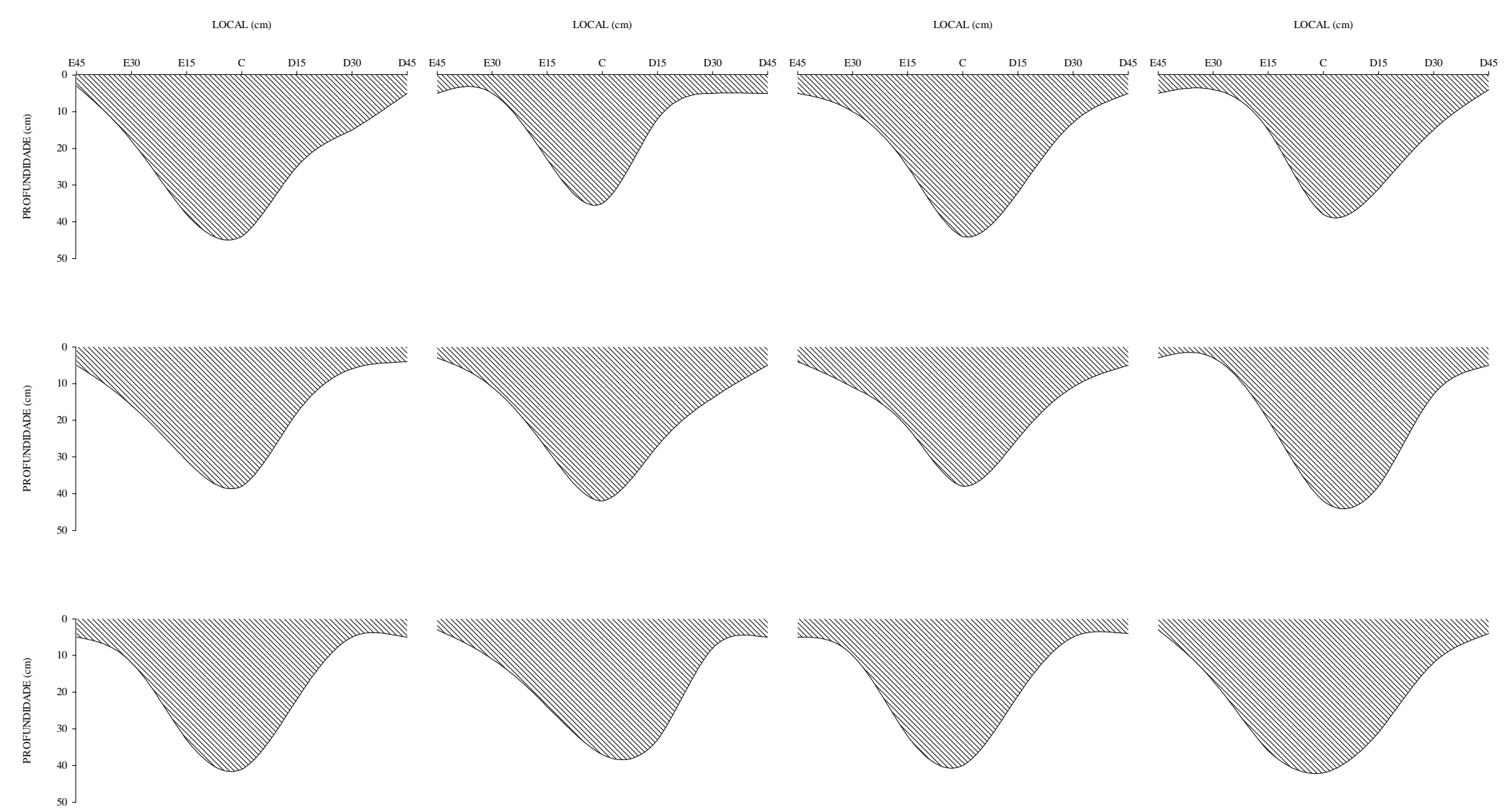
ANEXO T - Re-adensamento do sulco de preparo do LVd-2 (12 meses pós-preparo; $\theta=0,165 \mathrm{~cm}^{3} \mathrm{~cm}^{-3}$ )
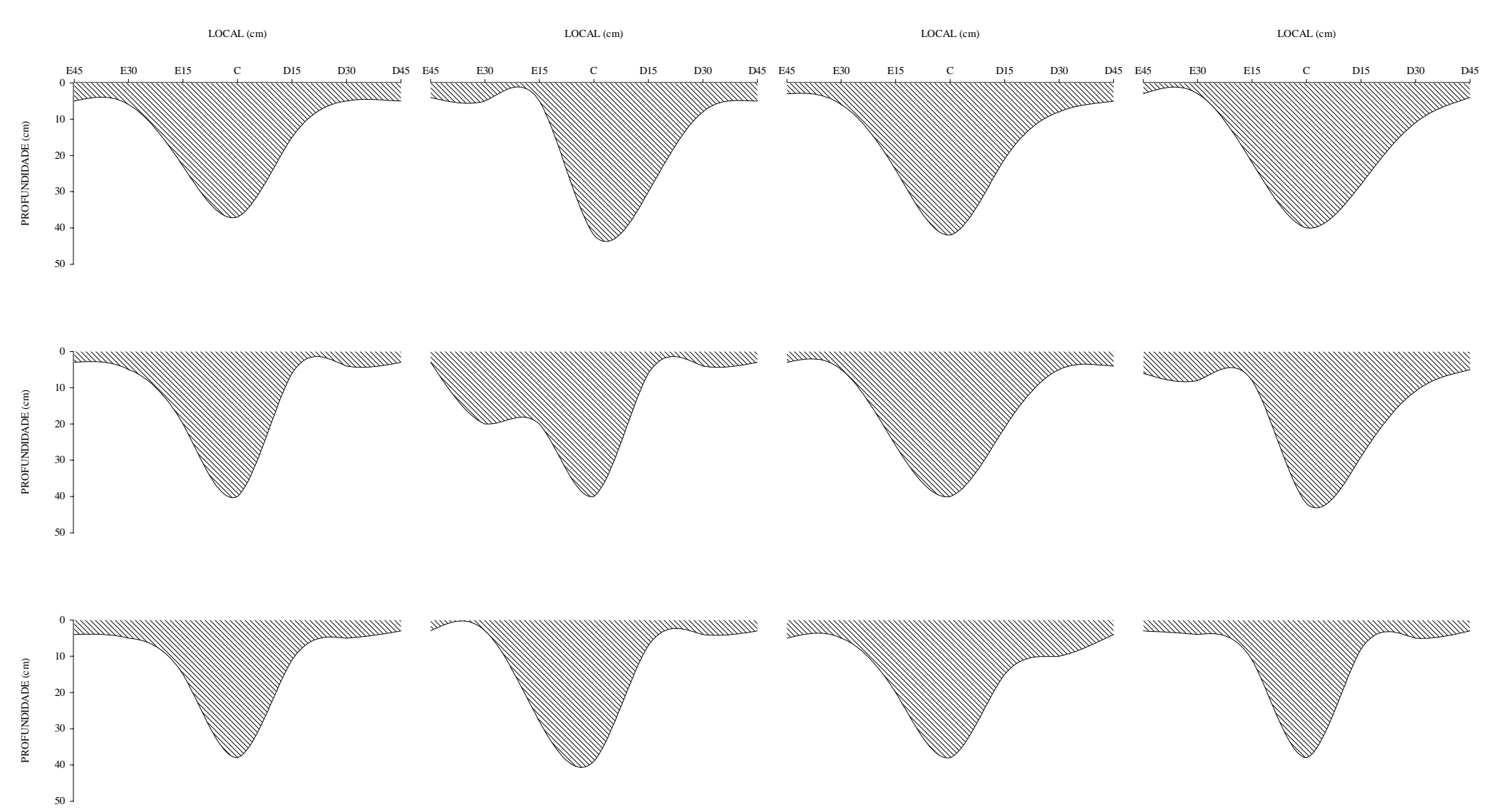
ANEXO U - Re-adensamento do sulco de preparo do LVd-2 (24 meses pós-preparo; $\theta=0,157 \mathrm{~cm}^{3} \mathrm{~cm}^{-3}$ )
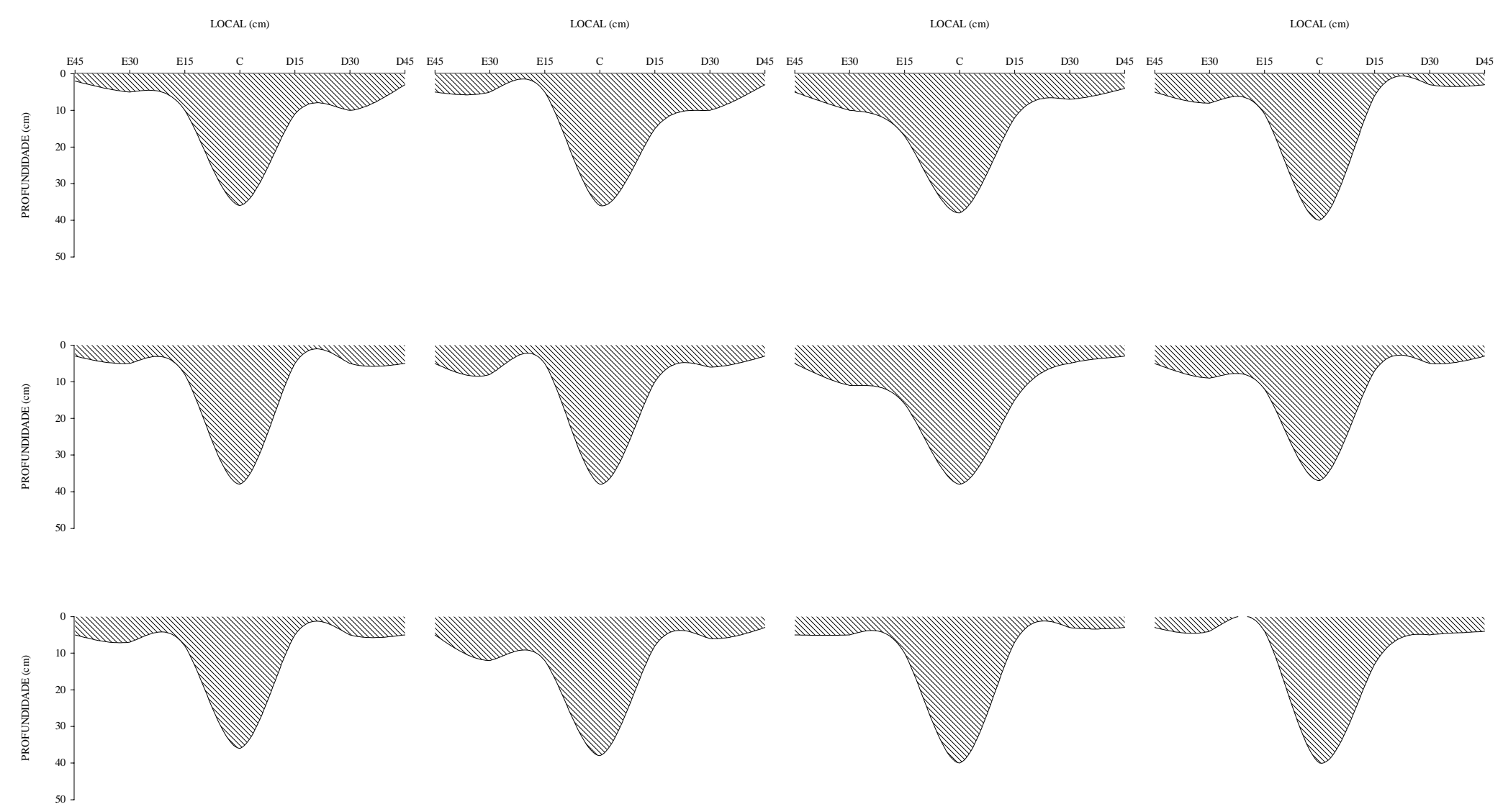


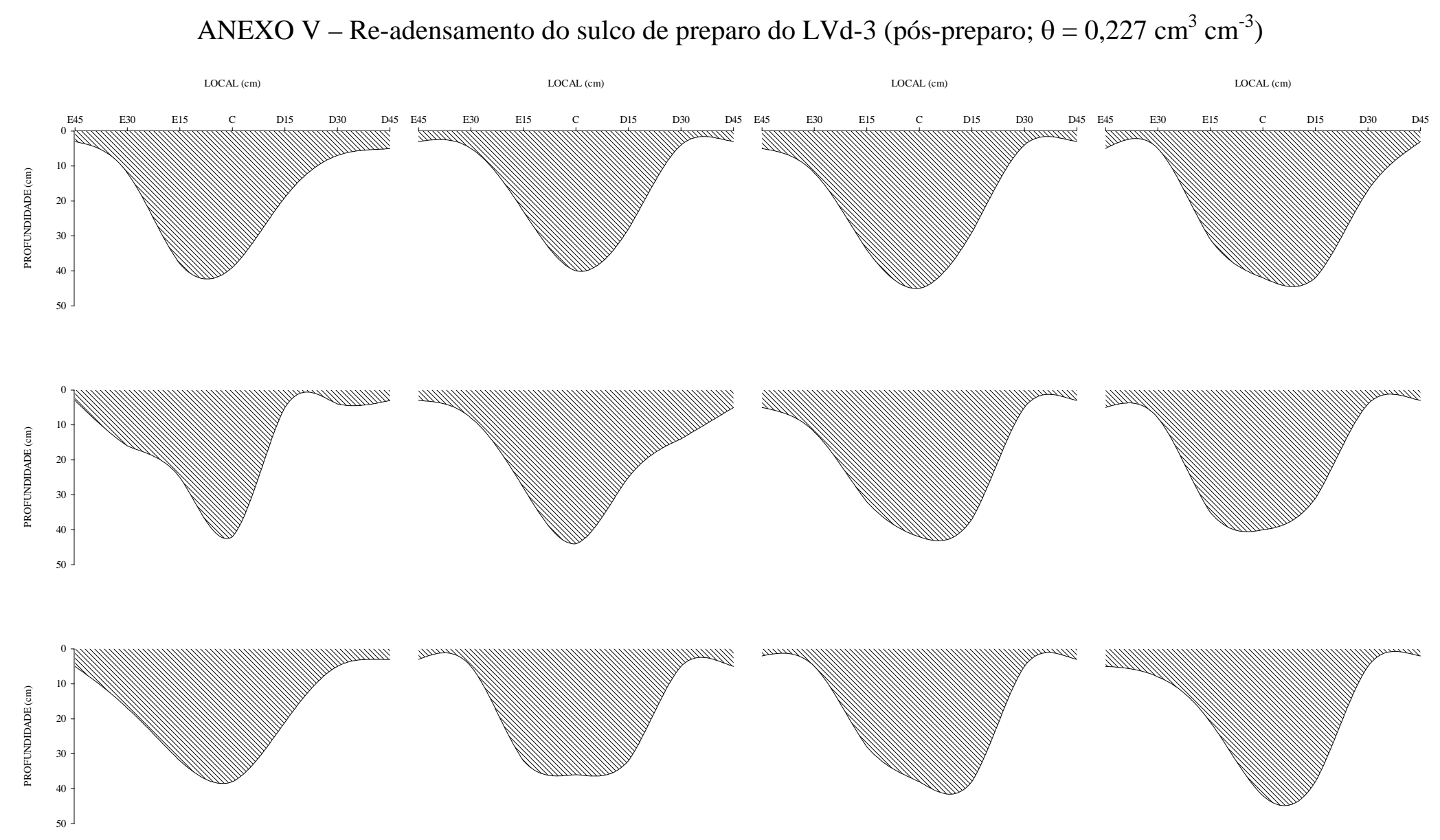


ANEXO W - Re-adensamento do sulco de preparo do LVd-3 (12 meses pós-preparo; $\theta=0,213 \mathrm{~cm}^{3} \mathrm{~cm}^{-3}$ )
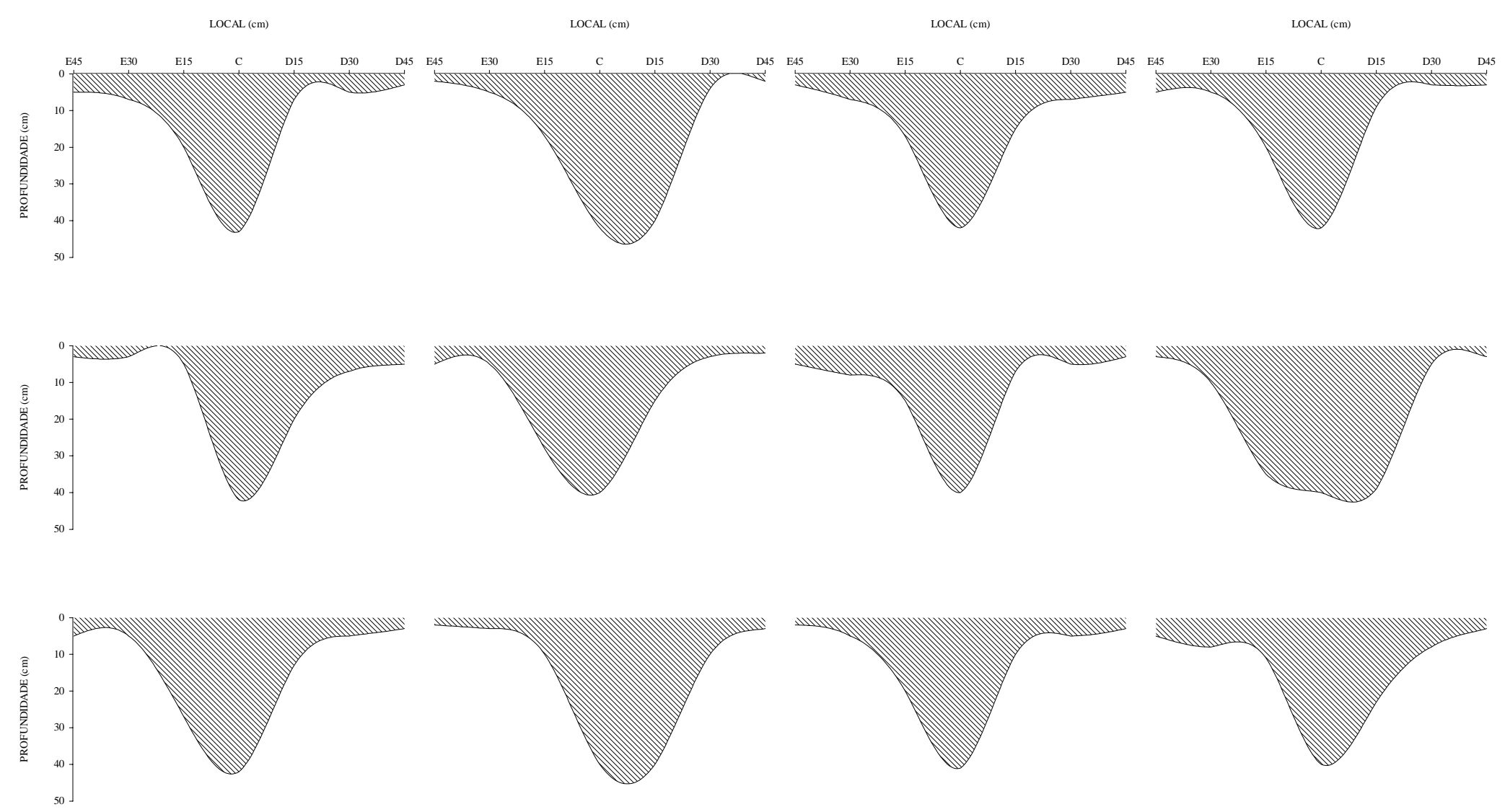
ANEXO X - Re-adensamento do sulco de preparo do LVd-3 (24 meses pós-preparo; $\theta=0,205 \mathrm{~cm}^{3} \mathrm{~cm}^{-3}$ )
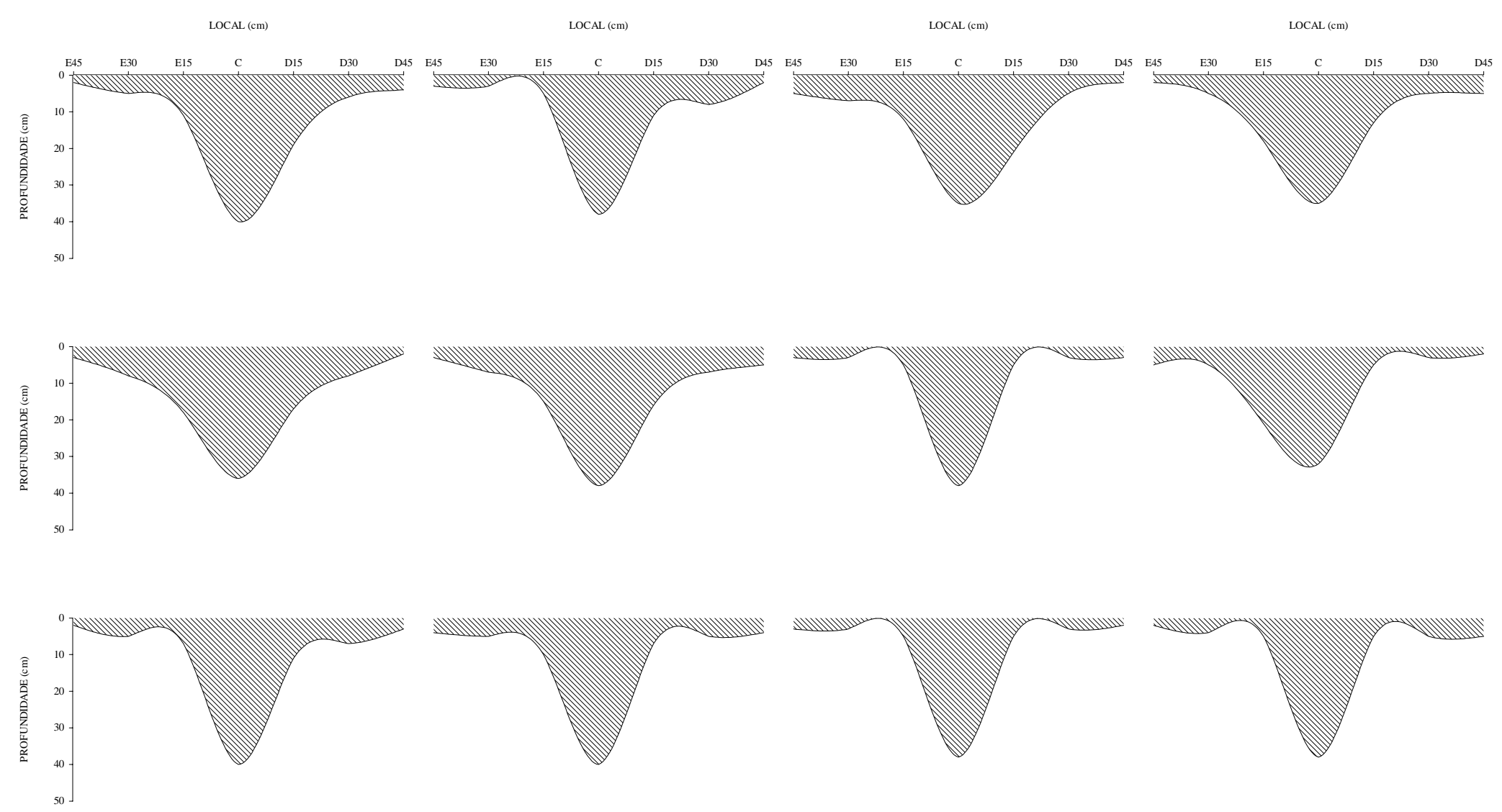